\title{
Anodic Coupling Reactions: A Sequential Cyclization Route to the Arteannuin Ring Skeleton
}

\author{
Honghui Wu and Kevin D. Moeller* \\ Department of Chemistry, Washington University, St. Louis, MO \\ moeller@wustl.edu
}

\section{Supplementary Material}

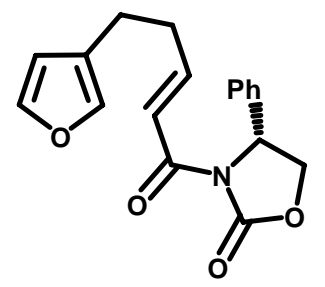

\section{3-(5-Furan-3-yl-pent-2-enoyl)-4(R)-phenyl-oxazolidin-2-one:}

In a $250 \mathrm{~mL}$ three necked flask, $5.23 \mathrm{~mL}(60.0 \mathrm{mmol})(\mathrm{COCl})_{2}$ in $120 \mathrm{~mL} \mathrm{CH}_{2} \mathrm{Cl}_{2}$ was cooled to $-78^{\circ} \mathrm{C}$ in acetone-dry ice bath. $8.5 \mathrm{~mL}(120 \mathrm{mmol}) \mathrm{DMSO}$ in $10 \mathrm{~mL} \mathrm{CH}_{2} \mathrm{Cl}_{2}$ was added in 5 minutes. Temperature was controlled below $-65^{\circ} \mathrm{C}$. After the reaction mixture was cooled back to $-78^{\circ} \mathrm{C}$, a solution of $3.79 \mathrm{~g}(30.0 \mathrm{mmol})$ alcohol $2 \mathrm{a}$ in $10 \mathrm{~mL}$ $\mathrm{CH}_{2} \mathrm{Cl}_{2}$ was added quickly within 2 minutes at $-78^{\circ} \mathrm{C}$. After stirred at $-78^{\circ} \mathrm{C}$ over 15 minutes, the reaction mixture was allowed to warm to room temperature and stirred for additional 1 hour. The reaction mixture was quenched with $100 \mathrm{~mL}$ of water. The aqueous layer was extracted three times with $30 \mathrm{~mL}$ of diethyl ether/pentane(1:1) solvent. The combined organic layers were washed with water, brine, dried over $\mathrm{MgSO}_{4}$, and concentrated in vacuo to about $15 \mathrm{~mL}$ total volume and then diluted with $25 \mathrm{~mL}$ of THF. The crude aldehyde was carried on to the next step without purification.

In a $250 \mathrm{~mL}$ three necked flask, $15.36 \mathrm{~g}$ (45.0 mmol) of a Horner-EmmonsWadsworth reagent $\left[(\mathrm{EtO})_{2} \mathrm{POCH}_{2} \mathrm{COXc}\right]$ was dissolved in $180 \mathrm{~mL}$ of THF and cooled to $0{ }^{\circ} \mathrm{C}$. To this solution was added $36 \mathrm{~mL}(23.7 \mathrm{mmol})$ of a $1.0 \mathrm{M}$ NaHMDS in THF solution at $0^{\circ} \mathrm{C}$. The reaction was stirred for $10 \mathrm{~min}$ and then allowed to warm to room temperature for $45 \mathrm{~min}$. The reaction was then cooled back to $0{ }^{\circ} \mathrm{C}$ and the aldehyde solution prepared above was added via a cannula over a $10 \mathrm{~min}$ period. The reaction mixture was stirred at $0^{\circ} \mathrm{C}$ for $2 \mathrm{~h}$ and then poured into a $\mathrm{pH}=7$ buffer solution. The aqueous layer was extracted with $40 \mathrm{~mL}$ of diethyl ether for three times. The combined organic solution was washed with brine, dried over $\mathrm{MgSO}_{4}$, and concentrated in vacuo. The product was then purified with silica gel column chromatographed with a mixed solvent (hexane: ethyl acetate $=4: 1$ ) to afford $7.54 \mathrm{~g}$ of product $(81 \%)$. ${ }^{1} \mathrm{H} \mathrm{NMR}$ $\left(300 \mathrm{MHz}, \mathrm{CDCl}_{3}\right) \delta 7.28-7.42(\mathrm{~m}, 6 \mathrm{H}), 7.22,(\mathrm{~s}, 1 \mathrm{H}), 7.10(\mathrm{dt}, 6.6 \mathrm{~Hz}, 15.3 \mathrm{~Hz}), 6.26(\mathrm{~s}$, $1 \mathrm{H}), 5.48\left(\mathrm{dd}, \mathrm{J}_{1}=3.9 \mathrm{~Hz}, \mathrm{~J}_{2}=8.7 \mathrm{~Hz}, 1 \mathrm{H}\right), 4.70\left(\mathrm{dd}, \mathrm{J}_{1}=\mathrm{J}_{2}=8.7 \mathrm{~Hz}, 1 \mathrm{H}\right), 4.28(\mathrm{dd}, \mathrm{J}$ 
$=3.9 \mathrm{~Hz}, \mathrm{~J}=8.7 \mathrm{~Hz}, 1 \mathrm{H}), 2.49-2.63(\mathrm{~m}, 4 \mathrm{H}) ;{ }^{13} \mathrm{C} \mathrm{NMR}\left(75 \mathrm{MHz}, \mathrm{CDCl}_{3}\right) \delta(164.7,153.9$, $150.8,143.1,129.4,128.9,126.2,123.8,121.0,111.0,70.2,58.0,33.2,23.6)$; FT-IR (neat) $\mathrm{cm}^{-1}(3135.9,3089.8,3032.8,2919.5,2856.8,1958.1,1777.3,1686.3,1635.5$, 1495.6, 1478.3, 1456.3, 1384.8, 1356.9, 1340.0, 1286.8, 1199.4, 1110.6, 1063.1, 1024.0, 1001.6, 971.2, 873.7, 784.2, 763.2, 709.9) ; LRMS: m/z (EI) 311.1, 189.0, 164.0, 148.0, 120.0, 83.9; HRMS (EI) $\left(\mathrm{M}^{+}\right)$calc. 311.1160, Found 311.1168

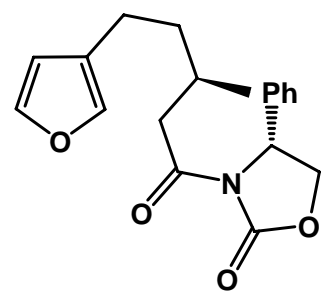

\section{3-(5-Furan-3-yl-3(R)-methyl-pentanoyl)-4(R)-phenyl-oxazolidin-2-one (3a):}

To a $100 \mathrm{~mL} 3$-necked flask equipped with thermometer, $11.1 \mathrm{~g}(54.3 \mathrm{mmol})$ of $\mathrm{CuBrMe}_{2} \mathrm{~S}$ was dissolved in $62 \mathrm{~mL}$ of dimethylsulfide and $94 \mathrm{~mL}$ of THF. This mixture was cooled to $-78{ }^{\circ} \mathrm{C}$ and then $23.5 \mathrm{~mL}(70.5 \mathrm{mmol}) \mathrm{MeMgCl}(3.0 \mathrm{M}$ in THF) added dropwise over $20 \mathrm{~min}$. After stirring for stirred $20 \mathrm{~min}$ at $-78^{\circ} \mathrm{C}$, the mixture was warmed to $0{ }^{\circ} \mathrm{C}$ for $20 \mathrm{~min}$ before cooling back to $-78^{\circ} \mathrm{C}$. The cuprate solution was transferred using a cannula to a suspension of $6.74 \mathrm{~g}(21.7 \mathrm{mmol})$ of the enoate made above in a mixed solvent of $55 \mathrm{~mL}$ THF and $28.2 \mathrm{~mL} \mathrm{CH}_{2} \mathrm{Cl}_{2}$ at $-78^{\circ} \mathrm{C}$ over $15 \mathrm{~min}$. The reaction mixture was stirred at $-78{ }^{\circ} \mathrm{C}$ for $1 \mathrm{~h}$, slowly warmed to $-30{ }^{\circ} \mathrm{C}$ over $1 \mathrm{~h}$, stirred at $-30{ }^{\circ} \mathrm{C}$ for $1 \mathrm{~h}$, and then quenched with a saturated $\mathrm{NH}_{4} \mathrm{Cl}$ solution. The aqueous layer was extracted three times with $80 \mathrm{~mL}$ of diethyl ether. The combined organic solution was washed with brine, dried over $\mathrm{MgSO}_{4}$, and concentrated in vacuo. Chromatography of the crude product through silica gel (hexane: ethyl acetate $=4: 1$ ) led to the isolation of $6.6 \mathrm{~g}$ $(93 \%)$ of the pure product. ${ }^{1} \mathrm{H}$ NMR $\left(300 \mathrm{MHz}, \mathrm{CDCl}_{3}\right) \delta 7.27-7.41(\mathrm{~m}, 6 \mathrm{H}), 7.16\left(\mathrm{dd}, \mathrm{J}_{1}\right.$ $\left.=0.9 \mathrm{~Hz}, \mathrm{~J}_{2}=1.8 \mathrm{~Hz}, 1 \mathrm{H}\right), 6.21\left(\mathrm{dd}, \mathrm{J}_{1}=\mathrm{J}_{2}=0.9 \mathrm{~Hz}, 1 \mathrm{H}\right), 5.43\left(\mathrm{dd}, \mathrm{J}_{1}=3.9 \mathrm{~Hz}, \mathrm{~J}_{2}=8.7\right.$ $\mathrm{Hz}, 1 \mathrm{H}), 4.68\left(\mathrm{dd}, \mathrm{J}_{1}=\mathrm{J}_{2}=8.7 \mathrm{~Hz}, 1 \mathrm{H}\right), 4.27\left(\mathrm{dd}, \mathrm{J}_{1}=3.9 \mathrm{~Hz}, \mathrm{~J}_{2}=8.7 \mathrm{~Hz}, 1 \mathrm{H}\right), 2.88(\mathrm{dd}$, $\left.\mathrm{J}_{1}=0.6 \mathrm{~Hz}, \mathrm{~J}_{2}=6.6 \mathrm{~Hz}, 2 \mathrm{H}\right), 2.30-2.50(\mathrm{~m}, 2 \mathrm{H}), 2.00-2.14(\mathrm{~m}, 1 \mathrm{H}), 1.54-1.66(\mathrm{~m}, 1 \mathrm{H})$, 1.34-1.46 (m, 1H), $0.92(\mathrm{~d}, \mathrm{~J}=6.6 \mathrm{~Hz}, 3 \mathrm{H}) ;{ }^{13} \mathrm{C} \mathrm{NMR}\left(75 \mathrm{MHz}, \mathrm{CDCl}_{3}\right) \delta 172.3,153.9$, $142.8,139.4,138.9,129.4,128.9,126.2,125.1,111.2,70.1,58.9,42.7,36.9,29.6,22,5$, 19.8; FT-IR (neat) 3137, 2945, 2923, 2857, 1779, 1703, 1494, 1456, 1371, 1381, 1328, 1229, 1210, 1066, 1022, 872, 786, 763, 701, $600 \mathrm{~cm}^{-1}$; LRMS: m/z (EI) 327.1, 246.1, 232.1, 205.1, 190.1, 164.1, 141.1, 136.1, 122.1, 103.1, 95.0, 94.0, 91.0, 82.0, 81.0,77.0; HRMS: (EI) $\left(\mathrm{M}^{+}\right)$clcd: 327.1471, found: 327.1470

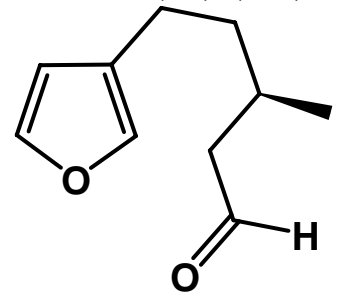

5-Furan-3-yl-3(R)-methyl-pentanal: 
Compound 3a $(0.886 \mathrm{~g}, 2.71 \mathrm{mmol})$ was dissolved in $27 \mathrm{~mL}$ of $\mathrm{CH}_{2} \mathrm{Cl}_{2}$ and cooled to $78^{\circ} \mathrm{C}$. To this solution was added dropwise over $20 \mathrm{~min} 5.42 \mathrm{~mL}(5.4 \mathrm{mmol})$ of a $1.0 \mathrm{M}$ DIBAL-H in cyclohexane solution. The mixture was stirred at $-78^{\circ} \mathrm{C}$ for $30 \mathrm{~min}$ and then quenched with a saturated aqueous Rochelle's salt solution. Thirty $\mathrm{mL}$ of diethyl ether was added and then the crude reaction stirred. The upper layer turned clear after 1 hour. The aqueous layer was then extracted two times with $30 \mathrm{~mL}$ of diethyl ether. The combined organic solution was washed with brine, dried over $\mathrm{MgSO}_{4}$, and concentrated in vacuo. The crude product was purified with flash chromatography through silica gel neutralized with $1 \% \mathrm{NEt}_{3}$ (pentane/diethyl ether $=4: 1$ ) to give $0.470 \mathrm{~g}(96 \%)$ of the purified aldehyde. ${ }^{1} \mathrm{H}$ NMR $\left(300 \mathrm{MHz}, \mathrm{CDCl}_{3}\right) \delta 9.79(\mathrm{t}, \mathrm{J}=2.1 \mathrm{~Hz}, 1 \mathrm{H}), 7.39(\mathrm{t}, \mathrm{J}=1.8$ $\mathrm{Hz}, 1 \mathrm{H}), 7.25\left(\mathrm{dd}, \mathrm{J}_{1}=1.2 \mathrm{~Hz}, \mathrm{~J}_{2}=1.5 \mathrm{~Hz}, 1 \mathrm{H}\right), 6.29(\mathrm{~d}, \mathrm{~J}=0.3 \mathrm{~Hz}, 1 \mathrm{H}), 2.38-2.50(\mathrm{~m}$, 2H), 2.29 (ddd, $\left.\mathrm{J}_{1}=2.7 \mathrm{~Hz}, \mathrm{~J}_{2}=7.8 \mathrm{~Hz}, \mathrm{~J}_{3}=16.5 \mathrm{~Hz}, 1 \mathrm{H}\right), 2.15(\mathrm{o}, \mathrm{J}=6.6 \mathrm{~Hz}, 1 \mathrm{H}), 1.46-$ $1.66(\mathrm{~m}, 2 \mathrm{H}), 1.03(\mathrm{~d}, \mathrm{~J}=6.9 \mathrm{~Hz}, 3 \mathrm{H}) ;{ }^{13} \mathrm{C} \mathrm{NMR}\left(75 \mathrm{MHz}, \mathrm{CDCl}_{3}\right) \delta 202.9 ; 143.2,139.0$, 124.9, 111.1, 51.2, 46.5, 37.2, 27.9, 22.5, 20.0; FT-IR (neat) 3146.3, 2929, 2858, 2721, 1723, 1501, 1459, 1382, 1159, 1065, 1023, 873, 783, 727, $600 \mathrm{~cm}^{-1} ;$ LRMS: m/z (EI) 166.1, 122.1, 109.1, 95.1, 82.1, 67.0 HRMS: (EI) $\left(\mathrm{M}^{+}\right)$clcd: 166.0994 found: 166.0993

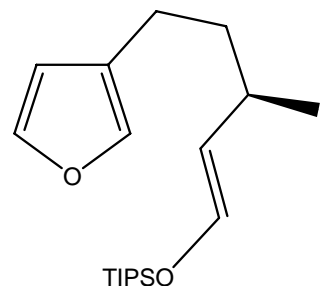

(5-Furan-3-yl-3(R)-methyl-pent-1-enyloxy)-triisopropyl-silane (4a):

The aldehyde made above $(0.99 \mathrm{~g}, 6.0 \mathrm{mmol})$ and $2.17 \mathrm{~mL}(17.3 \mathrm{mmol})$ of triethylamine were dissolved in $10 \mathrm{~mL}$ of $\mathrm{CH}_{2} \mathrm{Cl}_{2}$ and cooled to $0^{\circ} \mathrm{C}$. To this solution was added $1.86 \mathrm{~mL}(7.6 \mathrm{mmol})$ of TIPSOTf in a dropwise manner. The resulting solution was stirred overnight at room temperature. The solvent was removed in vacuo and then hexane added to precipitate out any salts. The reaction was filtered and then the hexane removed from the filtrate to afford $2.08 \mathrm{~g}$ of crude product (Crude yield $=100 \%$ ). After column chromatography on silica gel with hexane/diethyl ether $(20: 1), 1.87 \mathrm{~g}(90 \%)$ product was obtained. ${ }^{1} \mathrm{H}$ NMR $\left(300 \mathrm{MHz}, \mathrm{CDCl}_{3}\right) 7.32(\mathrm{~s}, 1 \mathrm{H}), 7.19(\mathrm{~s}, 1 \mathrm{H}), 6.27(\mathrm{~d}$, $\mathrm{J}=4.5 \mathrm{~Hz}, 1 \mathrm{H}), 6.26(\mathrm{~s}, 1 \mathrm{H}), 4.21\left(\mathrm{dd}, \mathrm{J}_{1}=6 \mathrm{~Hz}, \mathrm{~J}_{2}=9.3 \mathrm{~Hz}, 1 \mathrm{H}\right), 2.69-2.84,(\mathrm{~m}, 1 \mathrm{H})$, $2.41(\mathrm{o}, \mathrm{J}=8.4 \mathrm{~Hz}, 2 \mathrm{H}), 1.4-1.6(\mathrm{~m}, 2 \mathrm{H}), 0.95-1.2(\mathrm{~m}, 21 \mathrm{H}), 0.99(\mathrm{~d}, \mathrm{~J}=6.6 \mathrm{~Hz}, 3 \mathrm{H}) ;{ }^{13} \mathrm{C}$ NMR $\left(75 \mathrm{MHz}, \mathrm{CDCl}_{3}\right) \delta 142.7,138.9,138.6,125.8,115.8,111.4,38.2,28.6,23.1,21.4$, 18.0, 12.3. FT-IR (neat) 3023.6, 2945, 2867, 1653, 1502, 1463, 1404, 1384, 1256, 1181 , $1161,1108,1064,1027,883,874,777,685,666,640,599 \mathrm{~cm}^{-1}$. MS: LRMS (EI) (322.2, 307.2, 279.1, 240.1, 227.1, 197.1, 185.1, 157.1, 149.1, 135.1, 131.1, 115.1, 107.0, 103.0, 81.0, 81.0, 75.0, 61.0, 59.0); HRMS: (EI) $\left(\mathrm{M}^{+}\right)$clcd: 322.2328; found: 322.2341 


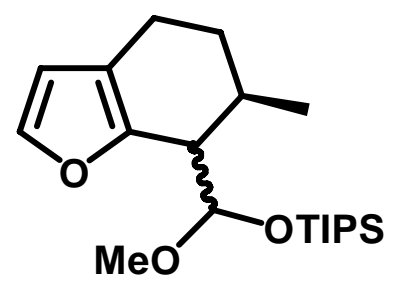

7(R)-(1-Methoxy-1-triisopropylsiloxymethyl)-6(R)-methyl-4,5,6,7-tetrahydrobenzofuran:

The silyl enol ether $(0.813 \mathrm{~g}, 2.5 \mathrm{mmol})$ was added along with $1.76 \mathrm{~mL}(15.2 \mathrm{mmol})$ of 2,6-lutidine to a $2.85 \mathrm{~g}(9.45 \mathrm{~mol})$ of $\mathrm{Et}_{4} \mathrm{NOTs}$ in $33 \%$ methanlol $(25.2 \mathrm{~mL})$ in dichloromethane $(50.4 \mathrm{~mL})$ electrolyte solution. The reaction flask was equipped with a reticulated vitreous carbon (RVC) and a carbon rod cathode. A constant current $(18 \mathrm{~mA})$ was passed through the solution until $2.05 \mathrm{~F} /$ mole of charge was consumed. At that point, $3.83 \mathrm{~g}(20.2 \mathrm{mmol})$ of $\mathrm{TsOH}$ was added and the resulting solution stirred for $1 \mathrm{~h}$. The reaction was the quenched with water, the layers separated, and the aqueous phase extracted three times with $20 \mathrm{~mL} \mathrm{CH}_{2} \mathrm{Cl}_{2}$. The reaction afforded $0.54 \mathrm{~g}(60 \%)$ of a crude product that looked clean by NMR. However, the molecule proved to be not sufficiently stable for further purification. Because the procedure using the enol ether initiating group turned out to not be general, work on this cyclization was not continued. ${ }^{1} \mathrm{H}$ NMR $\left(300 \mathrm{MHz}, \mathrm{CDCl}_{3}\right) \delta 7.31(\mathrm{~s}, 1 \mathrm{H}), 6.10(\mathrm{~s}, 1 \mathrm{H}), 4.42(\mathrm{~d}, \mathrm{~J}=6.0 \mathrm{~Hz}, 1 \mathrm{H}), 3.40(\mathrm{~d}, \mathrm{~J}=6 \mathrm{~Hz}$, $3 \mathrm{H}), 3.31(\mathrm{~d}, \mathrm{~J}=4.2 \mathrm{~Hz}, 1 \mathrm{H}), 2.44\left(\mathrm{dd}, \mathrm{J}_{1}=\mathrm{J}_{2}=3.0 \mathrm{~Hz}, 1 \mathrm{H}\right), 1.07-1.04(\mathrm{~m}, 21 \mathrm{H}), 1.00(\mathrm{~d}$, $\mathrm{J}=7.2 \mathrm{~Hz}, 3 \mathrm{H}) .\left(300 \mathrm{MHz}, \mathrm{CDCl}_{3}\right) \delta{ }^{13} \mathrm{C} 149.6,141.0,118.0,110.3,99.7,53.7,46.7$, 45.8, 28.5, 19.9, 19.3, 18.1, 12.8; IR(neat) 3148.1, 3103.4, 2943.3, 2866.6, 1805.3, 1731.3, 1682.8, 1562.6, 15044, 1463.6, 1381.3, 1335.5, 1237.6, 1211.2, 1130.7, 1083.4, $1069.5,1045.1,1012.1,997.5,883.1,832.0,773.4,7272.2,681.6 \mathrm{~cm}^{-1}$; MS LRMS (ESI) 353.1, 337.1, 321.1, 282.3, 235.1, 217.1; HRMS (EI) $\left(\mathrm{M}^{+}\right)$clcd: 352.2434, found: 352.2425

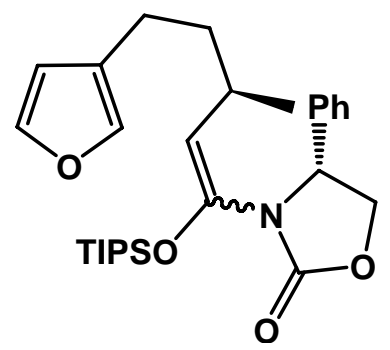

3-(5-Furan-3-yl-3(R)-methyl-1-triisopropylsilanyloxy-pent-1-enyl)-4(R)-phenyloxazolidin-2-one (6a):

In a $250 \mathrm{~mL}$ flame dried flask, $6.72 \mathrm{~g}(20.5 \mathrm{mmol})$ of imide 3a was dissolved in $123 \mathrm{~mL}$ of THF and cooled to $-78^{\circ} \mathrm{C}$. To this solution was added dropwise $20.5 \mathrm{~mL}$ of a $1.0 \mathrm{M}$ NaHMDS in THF solution over a period of $30 \mathrm{~min}$. The solution was stirred at $78^{\circ} \mathrm{C}$ for $2 \mathrm{~h}$. Then, $6.29 \mathrm{~g}(20.5 \mathrm{mmol})$ of TIPSOTf was added dropwise and stirred at $78^{\circ} \mathrm{C}$ for an additional $2 \mathrm{~h}$. The solvent was removed under reduced pressure. At that time, $100 \mathrm{~mL}$ of diethyl ether was added, the reaction filtered through a celite pad, and the 
resulting filtrate concentrated again. The residue was purified with hexane/ethyl acetate $(8: 1)$ as eluant through a silica gel column neutralized with $1 \% \mathrm{NEt}_{3}$. The column led to $9.12 \mathrm{~g}$ product $(92 \%)$ along with $0.27 \mathrm{~g}$ of recovered starting material. ${ }^{1} \mathrm{H}$ NMR $\left(300 \mathrm{MHz}, \mathrm{CDCl}_{3}\right) \delta$ 7.40-7.25 (m, 6H), $7.14(\mathrm{~d}, \mathrm{~J}=1.8 \mathrm{~Hz}, 1 \mathrm{H}) 6.2\left(\mathrm{dd}, \mathrm{J}_{1}=0.9 \mathrm{~Hz}, \mathrm{~J}_{2}=\right.$ $1.8 \mathrm{~Hz}, 1 \mathrm{H}), 5.00\left(\mathrm{dd}, \mathrm{J}_{1}=5.1 \mathrm{~Hz}, \mathrm{~J}_{2}=8.7 \mathrm{~Hz}, 1 \mathrm{H}\right), 4.63\left(\mathrm{t}, \mathrm{J}_{1}=\mathrm{J}_{2}=8.7 \mathrm{~Hz}, 1 \mathrm{H}\right), 4.30$ $\left(\mathrm{dd}, \mathrm{J}_{1}=5.1 \mathrm{~Hz}, \mathrm{~J}_{2}=8.7 \mathrm{~Hz}, 1 \mathrm{H}\right), 4.21(\mathrm{~d}, \mathrm{~J}=6.3 \mathrm{~Hz}, 1 \mathrm{H}), 2.39-2.29(\mathrm{~m}, 3 \mathrm{H}), 1.42$ (ddd, $\left.\mathrm{J}_{1}=7.5 \mathrm{~Hz}, \mathrm{~J}_{2}=5.1 \mathrm{~Hz}, \mathrm{~J}_{3}=1.2 \mathrm{~Hz}, 2 \mathrm{H}\right), 1.19-1.05(\mathrm{~m}, 21 \mathrm{H}), 0.61(\mathrm{~d}, \mathrm{~J}=6.9 \mathrm{~Hz}, 3 \mathrm{H})$;

${ }^{13} \mathrm{C}$ NMR $\left(75 \mathrm{MHz}, \mathrm{CDCl}_{3}\right) \delta 157.3,142.7,139.0,135.0,129.1,127.6,115.3,111.3$, 103,3, 100.2, 69.4, 60.4, 37.2, 29.8, 20.2, 18.1, 13.4; FT-IR (neat) 3097.6, 3048.8, 2946, $2867,1769,1678,1500,1459,1392,1361,1343,1282,1239,1200,1161,1119,1053$, 1026, 920, 883, 877, 782, 716, $687 \mathrm{~cm}^{-1}$; LRMS: $\mathrm{m} / \mathrm{z}\left(\mathrm{EI}^{+}\right)$483.3, 440.3, 396.3, 320.3, 292.2, 276.2, 232.2, 181.0, 162.1, 147.1 131.1,115.1, 103.1; HRMS (EI $\left.{ }^{+}\right)$: clcd: 483.2805, found 483.2803 .

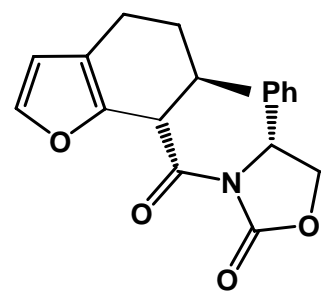

3(S)-(6(R)-Methyl-4,5,6,7-tetrahydro-benzofuran-7-carbonyl)-4(R)-phenyloxazolidin-2-one (7a):

In a three necked flask, $2.5 \mathrm{~g}(5.0 \mathrm{mmol})$ of N,O-ketene acetal $6 \mathrm{a}, 5.65 \mathrm{~g}(18.8$ mol) $\mathrm{Et}_{4} \mathrm{NOTs}$, and $3.48 \mathrm{~mL}(30.0 \mathrm{mmol})$ of 2,6-lutidine was dissolved in a mixture of $150 \mathrm{~mL} \mathrm{CH}_{2} \mathrm{Cl}_{2}$ and $37.5 \mathrm{~mL}$ methanol. A current passed of $20 \mathrm{~mA}$ was passed through the solution until $2.4 \mathrm{~F} / \mathrm{mol}$ of charge was consumed. The reaction was monitored for the loss of starting material by TLC. After completion of the reaction, $6.85 \mathrm{~g}(36 \mathrm{mmol})$ of TsOH $\mathrm{H}_{2} \mathrm{O}$ was added and the mixture stirred for $4 \mathrm{~h}$. Triethylamine $(3 \mathrm{~mL})$ was added and the solvent removed in vacuo. To the residue was added $100 \mathrm{~mL}$ of $\mathrm{Et}_{2} \mathrm{O}$ and the resulting solution filtered through a celite pad. After concentration of the filtrate, the residue was chromatographed through a silica gel column with hexane/ethyl acetate $(5: 1)$ as eluant to afford $1.138 \mathrm{~g}(70 \%)$ of the product. ${ }^{1} \mathrm{H}$ NMR $\left(300 \mathrm{MHz}, \mathrm{CDCl}_{3}\right) \delta 7.40-7.29$ $(\mathrm{m}, 5 \mathrm{H}), 7.25\left(\mathrm{dd}, \mathrm{J}_{1}=0.6 \mathrm{~Hz}, \mathrm{~J}_{2}=1.8 \mathrm{~Hz}, 1 \mathrm{H}\right), 6.18(\mathrm{~d}, \mathrm{~J}=1.8 \mathrm{~Hz}, 1 \mathrm{H}), 5.49\left(\mathrm{dd}, \mathrm{J}_{1}=\right.$ $\left.3.9 \mathrm{~Hz}, \mathrm{~J}_{2}=5.7 \mathrm{~Hz}, 1 \mathrm{H}\right), 4.78(\mathrm{~d}, \mathrm{~J}=5.4 \mathrm{~Hz}, 1 \mathrm{H}), 4.75(\mathrm{t}, \mathrm{J}=9.0 \mathrm{~Hz}, 1 \mathrm{H}), 4.32\left(\mathrm{dd}, \mathrm{J}_{1}=\right.$ $\left.3.9 \mathrm{~Hz}, \mathrm{~J}_{2}=9.0 \mathrm{~Hz}, 1 \mathrm{H}\right), 2.41\left(\mathrm{dt}, \mathrm{J}_{1}=1.8 \mathrm{~Hz}, \mathrm{~J}_{2}=6.0 \mathrm{~Hz}, 2 \mathrm{H}\right), 2.33-2.24(\mathrm{~m}, 1 \mathrm{H}), 1.61-$ $1.56(\mathrm{~m}, 4 \mathrm{H}), 1.49\left(\mathrm{dh}, \mathrm{J}_{1}=6 \mathrm{~Hz}, \mathrm{~J}_{2}=7.5 \mathrm{~Hz}, 1 \mathrm{H}\right), 1.03(\mathrm{~d}, \mathrm{~J}=6.9 \mathrm{~Hz}, 3 \mathrm{H}) ;{ }^{13} \mathrm{C} \mathrm{NMR}$ $\left(75 \mathrm{MHz}, \mathrm{CDCl}_{3}\right) \delta 174.4,153.8,146.5,141.8,139.4,129.4,129.0,126.2,118.9,110.5$, 70.1, 58.2, 46.0, 32.4, 28.3, 19.9 19.2; FT-IR (neat) 3033, 2962, 2930, 1780, 1704, 1503, 1457, 1384, 1326, 1231, 1207, 1105, 1042, 758, 733, 710, 698, 644, $531 \mathrm{~cm}^{-1}$; LRMS: $\mathrm{m} / \mathrm{z}$ (EI) 325.2, 162.1, 135.2, 119.1, 105.1, 91.1, 77.0, 69.0; HRMS: (EI) $\left(\mathrm{M}^{+}\right)$clcd. 325.1314 , found 325.1307 . 


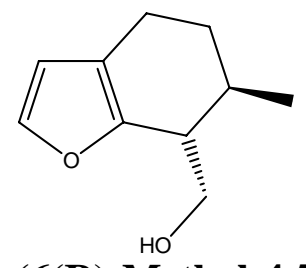

(6(R)-Methyl-4,5,6,7-tetrahydro-benzofuran-7(R)-yl)-methanol

In a $100 \mathrm{~mL}$ flamed dried flask, compound 7a $(2.5 \mathrm{~g}, 7.7 \mathrm{mmol})$ was dissolved in $52 \mathrm{~mL}$ of anhydrous diethyl ether and $1.24 \mathrm{~mL}(30.7 \mathrm{mmol})$ of methanol. The solution was cooled to $0{ }^{\circ} \mathrm{C}$ with an ice-water bath, and then $15.4 \mathrm{~mL}(30.7 \mathrm{mmol})$ of a $2.0 \mathrm{M}$ $\mathrm{LiBH}_{4}$ in THF solution added dropwise over $45 \mathrm{~min}$. The mixture was stirred at $0^{\circ} \mathrm{C}$ for $2 \mathrm{~h}$ and then quenched with an aqueous saturated $\mathrm{NaHCO}_{3}$ solution. The layers were separated and the aqueous layer extracted three times with $50 \mathrm{~mL}$ of diethyl ether. The combined organic layer was washed with brine, dried over $\mathrm{MgSO}_{4}$, and concentrated in vacuo. The crude product was purified by chromatography through silica gel using pentane/diethyl ether (4:1) as eluant to afford $1.2 \mathrm{~g}(94 \%)$ of the isolated product. ${ }^{1} \mathrm{H}$ $\operatorname{NMR}\left(300 \mathrm{MHz}, \mathrm{CDCl}_{3}\right) \delta 7.21(\mathrm{~d}, \mathrm{~J}=1.8 \mathrm{~Hz}, 1 \mathrm{H}), 6.14(\mathrm{~d}, \mathrm{~J}=1.8 \mathrm{~Hz}, 1 \mathrm{H}), 3.91$ (ddd, $\mathrm{J}_{1}$ $\left.=4.2 \mathrm{~Hz}, \mathrm{~J}_{2}=7.2 \mathrm{~Hz}, \mathrm{~J}_{3}=11.4 \mathrm{~Hz}, 1 \mathrm{H}\right), 3.68\left(\mathrm{td}, \mathrm{J}_{1}=5.4 \mathrm{~Hz}, \mathrm{~J}_{2}=11.4 \mathrm{~Hz}, 1 \mathrm{H}\right), 2.37-$ $2.45(\mathrm{~m}, 1 \mathrm{H}), 2.41-2.36(\mathrm{~m}, 2 \mathrm{H}), 1.71-1.84(\mathrm{~m}, 3 \mathrm{H}), 1.36-1.45(\mathrm{~m}, 1 \mathrm{H}), 1.02(\mathrm{~d}, \mathrm{~J}=3.3$ $\mathrm{Hz}, 3 \mathrm{H}) ;{ }^{13} \mathrm{C} \mathrm{NMR}\left(75 \mathrm{MHz}, \mathrm{CDCl}_{3}\right) \delta 151.5,141.4,118.5,110.6,63.8,44.7,30.8,30.7$, 20.9, 19.7; FT-IR (neat) 3400(br), 2954, 2926, 2852, 1742, 1678, 1504, 1457, 1378, 1203, 1161, 1109, 1060, 1033, 976, 890, 726, $598 \mathrm{~cm}^{-1}$; LRMS: m/z (EI) 166.1, 151.1, 135.1, 115.1,105.1, 91.1, 86.0, 84.0, 79.1, 77.1, 73.1 HRMS (EI) $\left(\mathrm{M}^{+}\right)$clcd: 166.0994, HRMS 166.0986

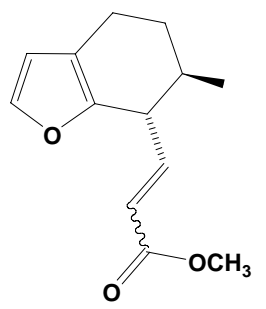

\section{3-(6-Methyl-4,5,6,7-tetrahydro-benzofuran-7-yl)-acrylic acid methyl ester:}

In a $100 \mathrm{~mL}$ flame dried flask, $(\mathrm{COCl})_{2} 0.73 \mathrm{~mL}(8.34 \mathrm{mmol})$ was dissolved in $15 \mathrm{~mL} \mathrm{CH} \mathrm{Cl}_{2}$ and cooled to $-78^{\circ} \mathrm{C}$. $1.18 \mathrm{~mL}(16.68 \mathrm{mmol})$ DMSO in $3 \mathrm{~mL} \mathrm{CH}_{2} \mathrm{Cl}_{2}$ was added in 2 minutes at $-78^{\circ} \mathrm{C}$. After stirred for 5 minutes, alcohol $0.69 \mathrm{~g}(4.17 \mathrm{mmol})$ in $2 \mathrm{~mL} \mathrm{CH}_{2} \mathrm{Cl}_{2}$ was added at $-78^{\circ} \mathrm{C}$. The reaction mixture was stirred for $15 \mathrm{~min}$ and then $5.81 \mathrm{~mL}(41.7 \mathrm{mmol}) \mathrm{NEt}_{3}$ was added dropwise. After stirred at $-78^{\circ} \mathrm{C}$ over 30 minutes, the reaction mixture was allowed to warm to room temperature for $1 \mathrm{~h}$ and then was quenched with $30 \mathrm{~mL}$ of ice water, the layers separated, and the aqueous layer extracted three times with $20 \mathrm{~mL}$ each of a mixed pentane/diethyl ether (1:1) solution. The combined solution was washed with brine and concentrated to $10 \mathrm{~mL}$. In another $100 \mathrm{~mL}$ flame dried flask, $0.334 \mathrm{~g}(8.34 \mathrm{mmol})$ of $60 \% \mathrm{NaH}$ was suspended in $10 \mathrm{~mL}$ of pentane. The solvent was removed with a syringe to wash away the oil used to stabilize the $\mathrm{NaH}$. This process was 
repeated followed by the addition of $33 \mathrm{~mL}$ of dry THF. The reaction was cooled to $0{ }^{\circ} \mathrm{C}$ and $1.75 \mathrm{~g}(8.34 \mathrm{mmol})$ of $(\mathrm{EtO})_{2} \mathrm{POCH}_{2} \mathrm{CO}_{2} \mathrm{CH}_{3}$ added over $10 \mathrm{~min}$. The mixture was allowed to warm to room temperature for $1 \mathrm{~h}$ and then cooled back to $0^{\circ} \mathrm{C}$. The crude aldehyde product was added dropwise at $0{ }^{\circ} \mathrm{C}$. After stirring at $0{ }^{\circ} \mathrm{C}$ for 2 hours, the reaction mixture was quenched with a saturated $\mathrm{NH}_{4} \mathrm{Cl}$ solution. The aqueous phase was extracted two times with $20 \mathrm{~mL}$ pentane/diethyl ether (10:1). The combined organic solution was concentrated in vacuo and the crude product chromatographed through silica gel to afford $0.82 \mathrm{~g}(89 \%)$ of the purified product. ${ }^{1} \mathrm{H}$ NMR $\left(300 \mathrm{MHz}, \mathrm{CDCl}_{3}\right) \delta 7.25(\mathrm{~s}$, $1 \mathrm{H}), 6.84\left(\mathrm{dd}, \mathrm{J}_{1}=8.7 \mathrm{~Hz}, \mathrm{~J}_{2}=15.3 \mathrm{~Hz}, 1 \mathrm{H}\right), 6.21(\mathrm{~d}, \mathrm{~J}=2.1 \mathrm{~Hz}, 1 \mathrm{H}), 5.93(\mathrm{~d}, \mathrm{~J}=15.3$ $\mathrm{Hz}, 1 \mathrm{H}), 3.74(\mathrm{~s}, 3 \mathrm{H}), 3.13(\mathrm{t}, \mathrm{J}=8.1 \mathrm{~Hz}, 1 \mathrm{H}), 2.44-2.49(\mathrm{~m}, 2 \mathrm{H}), 1.78-1.90(\mathrm{~m}, 2 \mathrm{H})$, $1.44-1.54(\mathrm{~m}, 1 \mathrm{H}), 1.04(\mathrm{~d}, \mathrm{~J}=6.6 \mathrm{~Hz}, 3 \mathrm{H}) ;{ }^{13} \mathrm{C} \mathrm{NMR}\left(75 \mathrm{MHz}, \mathrm{CDCl}_{3}\right) \delta(167.0,149.4$, 149.0, 141.9, 123.2, 118.0, 110.5, 51.7, 45.7, 35.1, 30.2, 29.9, 21.0, 19.4); FT-IR neat 3144.0 , 3111.5, 2949.5, 2927.3, 2855.6, 1725.2, 1657.9, 1503.6, 1453.8, 1435.7, 1378.9, $1340.5,1322.8,1275.0,1237.3,1209.0,1192.8,1158.4,1109.8,1036.1,981.9,893.4$, 854.8, 734.1, 676.9; MS. LRMS: m/z (EI) 220.1, 205.1, 189.1, 178.0, 161.1, 145.0, 135.1, 133.1, 131.1, 119.0, 105.0, 97.1, 91.0, 83.1, 77.0, 71.1, 69.0, 65.0; HRMS (EI) $\left(\mathrm{M}^{+}\right)$ clcd.: 220.1099, found: 220.1095 .

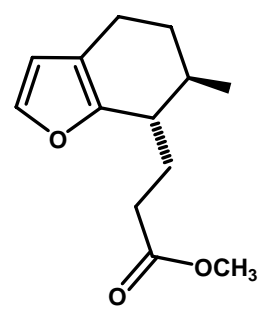

\section{3-(6-Methyl-4,5,6,7-tetrahydro-benzofuran-7-yl)-propionic acid methyl ester (8a)}

The methyl ester $(1.15 \mathrm{~g}, 5.2 \mathrm{mmol})$ and $\mathrm{NiCl}_{2} \cdot 6 \mathrm{H}_{2} \mathrm{O}(0.124 \mathrm{~g}, 0.52 \mathrm{mmol})$ were dissolved in $16.8 \mathrm{~mL}$ of $\mathrm{MeOH}$. The mixture was cooled to $0{ }^{\circ} \mathrm{C}$ and $\mathrm{NaBH}_{4}(0.379 \mathrm{~g}$, $10.5 \mathrm{mmol}$ ) added in portions over a period of $5 \mathrm{~min}$. The solution turned black during the addition. The reaction mixture was stirred at $0{ }^{\circ} \mathrm{C}$ for $1 \mathrm{~h}$ and then quenched with 20 $\mathrm{mL}$ of a saturated aqueous $\mathrm{NaHCO}_{3}$ solution. After filtration through a pad of celite, the filtrate was extracted three times with $20 \mathrm{~mL}$ of diethyl ether. The combined organic phase was washed with brine and dried over $\mathrm{MgSO}_{4}$. The solution was concentrated by distillation (important). When most of the solvent was removed, the residue was placed briefly on a rotory evaporator to obtain $1.11 \mathrm{~g}(93 \%)$. No further purification was needed. ${ }^{1} \mathrm{H}$ NMR $\left(300 \mathrm{MHz}, \mathrm{CDCl}_{3}\right) \delta 7.25(\mathrm{~s}, 1 \mathrm{H}), 6.16(\mathrm{~s}, 1 \mathrm{H}), 3.67(\mathrm{~s}, 3 \mathrm{H}), 2.52\left(\mathrm{ddd}, \mathrm{J}_{1}=5.7\right.$ $\left.\mathrm{Hz}, \mathrm{J}_{2}=6 \mathrm{~Hz}, \mathrm{~J}_{3}=16.5 \mathrm{~Hz}, 1 \mathrm{H}\right), 2.36\left(\mathrm{ddd}, \mathrm{J}_{1}=5.7 \mathrm{~Hz}, \mathrm{~J}_{2}=6 \mathrm{~Hz}, \mathrm{~J}_{3}=16.5 \mathrm{~Hz}, 1 \mathrm{H}\right)$, 2.07-2.16 (m, 1H), 1.69-1.93 (m, 3H), $1.38-1.50(\mathrm{~m}, 1 \mathrm{H}), 1.07(\mathrm{~d}, \mathrm{~J}=6.6 \mathrm{~Hz}, 3 \mathrm{H}) ;{ }^{13} \mathrm{C}$ NMR $\left(75 \mathrm{MHz}, \mathrm{CDCl}_{3}\right) \delta 174.5,153.0,141.9,117.1,110.3,51.7,40.8,33.7,31.9,30.0$, 27.5, 20.7, 19.5; FT-IR (neat) 3144.0, 3103.4, 2953.4, 2928.5, 2872.2, 1737.2, 1504.3, $1437.3,1377.9,1318.2,1257.8,1198.8,1169.2,1107.8,1037.8,1010.7,887.3,731.9 \mathrm{~cm}^{-}$ 1; LRMS: m/z (EI) 222.1, 191.1, 180.1, 161.1, 148.1, 135.1, 121.1, 97.0, 91.0, 84.0, 71.0, 69.0, 57.0; HRMS: (EI) $\left(\mathrm{M}^{+}\right)$clcd. 222.1256, found 222.1222. 


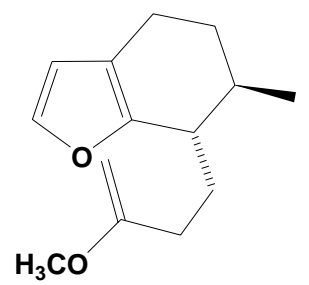

\section{7(S)-(3-Methoxy-but-3-enyl)-6(R)-methyl-4,5,6,7-tetrahydro-benzofuran (9a):}

In a flame dried $50 \mathrm{~mL}$ round bottom flask, ester 8a $(0.55 \mathrm{~g}, 2.5 \mathrm{mmol})$ was mixed with $12.25 \mathrm{~g}$ of a $8.5 \%$ solution of $\mathrm{Cp}_{2} \mathrm{TiMe}_{2}$ in toluene. The mixture was stirred at $60 \sim 65^{\circ} \mathrm{C}$ overnight under an atmosphere of Argon. After cooling to room temperature, the reaction mixture was diluted with $100 \mathrm{~mL}$ of pentane to precipitate the excess $\mathrm{Cp}_{2} \mathrm{TiMe}_{2}$ and then filtered through a pad of celite. The filtrate was concentrated by distillation of the pentane. The residue was separated with an alumina column (Activity III) to give $0.39 \mathrm{~g}$ of the enol ether electrolysis substrate $(71 \%) .{ }^{1} \mathrm{H}$ NMR $(300 \mathrm{MHz}$, $\left.\mathrm{CD}_{3} \mathrm{COCD}_{3}\right) \delta 7.33(\mathrm{~d}, \mathrm{~J}=1.8 \mathrm{~Hz}, 1 \mathrm{H}), 6.19(\mathrm{~d}, \mathrm{~J}=1.8 \mathrm{~Hz}, 1 \mathrm{H}), 3.89(\mathrm{~d}, \mathrm{~J}=1.8 \mathrm{~Hz}, 1 \mathrm{H})$, $3.87(\mathrm{~d}, \mathrm{~J}=1.8 \mathrm{~Hz}, 1 \mathrm{H}), 3.51(\mathrm{~s}, 3 \mathrm{H}), 2.41-2.34(\mathrm{~m}, 3 \mathrm{H}), 2.29-2.21(\mathrm{~m}, 1 \mathrm{H}), 2.14-2.04(\mathrm{~m}$, $1 \mathrm{H}), 1.95-1.70(\mathrm{~m}, 3 \mathrm{H}), 1.51-1.39(\mathrm{~m}, 1 \mathrm{H}), 1.02(\mathrm{~d}, \mathrm{~J}=4.2 \mathrm{~Hz}, 3 \mathrm{H}) ;{ }^{13} \mathrm{C}$ NMR $(75 \mathrm{MHz}$, $\left.\mathrm{CD}_{3} \mathrm{COCD}_{3}\right) \delta 164.5,153.3,140.9,116.6,110.2,80.0,54.3,40.8,33.2,32.5,30.2,29.5$, 20.2, 18.8; FT-IR (neat) 3117, 2955, 2927, 2852, 1717, 1684, 1654, 1625, 1603,1504, 1450, 1377, 1268, 1142, 1066, 1038, 892, 799, $729 \mathrm{~cm}^{-1}$; LRMS: m/z (EI) 220.1, 226.1, 189.1, 148.1, 133.1, 135.1, 105.1, 91.1, 88.1, 85.1; HRMS: (EI) (M ) clcd. 220.1463, found 220.1449 .

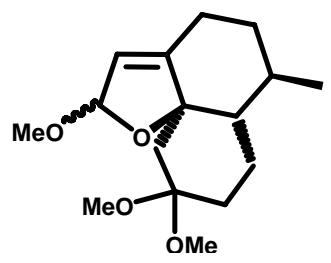

\section{2,9,9-Trimethoxy-6(R)-methyl-4,5,6,6a,7,8,9,10-octahydro-2H-1-oxa-cyclopenta naphthalene (10a):}

Electrolysis substrate 9a (79 mg, $0.36 \mathrm{mmol})$ was dissolved in $11.5 \mathrm{~mL}$ of $\mathrm{CH}_{2} \mathrm{Cl}_{2}$ and $2.9 \mathrm{~mL}$ of methanol together with $0.231 \mathrm{~g}(2.15 \mathrm{mmol})$ of 2,6-lutidine and $0.142 \mathrm{~g}$ (1.34 mmol) of $\mathrm{LiClO}_{4}$ in a $25 \mathrm{~mL}$ three necked flask. The flask was fitted with an RVC anode $(6 \mathrm{~mm}$ X $6 \mathrm{~mm}$ X $6 \mathrm{~mm})$ and graphite cathode. A constant current of $8 \mathrm{~mA}$ was passed through the cell until $2.2 \mathrm{~F} /$ mole of charge was consumed. At that point, there was no starting material left by TLC. The reaction mixture was then washed with water, the layers separated, and the aqueous layer extracted three times with $30 \mathrm{~mL}$ of diethyl ether. To the combined organic layer was added $95.5 \mathrm{mg}(0.36 \mathrm{mmol})$ of 2,4-dibromoanisole as an internal NMR standard. The NMR yield for the reaction was found to be $87 \%$. The solution was then carefully titrated with $20 \mathrm{~mL}$ of a $0.1 \mathrm{~N}$ aqueous $\mathrm{HCl}$ solution. The layers were separated and the organic phase was washed with brine, dried over $\mathrm{MgSO}_{4}$, and concentrated in vacuo. The crude product was chromatographed through a silica gel column using with pentane/diethyl ether (2:1) as eluant in order to afford $71 \mathrm{mg}(70 \%)$ of 
the isolated product 10a. Two stereoisomers were obtained at the five membered ring acetal carbon in a 3.5:1 ratio. ${ }^{1} \mathrm{H}$ NMR $\left(300 \mathrm{MHz}, \mathrm{CDCl}_{3}\right) \delta 5.74(\mathrm{~d}, 1.2 \mathrm{H}, 0.22 \mathrm{H}), 5.51(\mathrm{~s}$, $0.78 \mathrm{H}), 5.36(\mathrm{~s}, 0.78 \mathrm{H}), 5.30(\mathrm{~s}, 0.22 \mathrm{H}), 3.48(\mathrm{~s}, 2.34 \mathrm{H}), 3.36(\mathrm{~s}, 0.66 \mathrm{H}), 3.244(\mathrm{~s}, 2.34 \mathrm{H})$, $3.235(\mathrm{~s}, 0.66 \mathrm{H}), 3.19(\mathrm{~s} 3 \mathrm{H}), 2.51-2.44(\mathrm{~m}, 1 \mathrm{H}), 2.15-1.63(\mathrm{~m}, 8 \mathrm{H}), 1.45-1.20(\mathrm{~m}, 2 \mathrm{H})$, 1.16-0.96 (m, 2H), $0.89(\mathrm{~d}, \mathrm{~J}=3.6 \mathrm{~Hz}, 3 \mathrm{H}) ;{ }^{13} \mathrm{C}$ NMR $\left(75 \mathrm{MHz}, \mathrm{CDCl}_{3}\right)$ major $\delta 151.8$, $116.7,108.7,100.3,88.4,56.0,50.9,48.2,47.3,37.2,36.4,30.6,27.5,26.1,20.3,19.1$; minor $\delta 151.8,116.7,108.2,100.3,89.7,53.6,50.7,48.5,47.3,36.8,36.6,30.3,27.4$, 26.1, 20.2, 19.1; FT-IR (neat) 2943, 2826, 1677, 1444, 1374, 1264, 1181, 1154, 1112, 1091, 1052, 1033, 954, 938, 904, 824, 808, 674. LRMS: m/z (EI) 282.2, 267.2, 251.1, 235.1, 219.1, 207.1, 197.1, 179.1, 142.1, 119.1, 115.0, 101.0, 75.0 HRMS: (EI) $\left(\mathrm{M}^{+}\right)$clcd: 282.1831 found: 282.1826

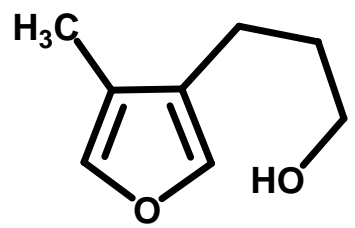

\section{3-(4-Methyl-furan-3-yl)-propan-1-ol (2b):}

In a $250 \mathrm{~mL}$ flame dried three necked flask, $14.6 \mathrm{~g}(90 \mathrm{mmol})$ of 3-bromo-4methylfuran was dissolved in $116 \mathrm{~mL}$ of freshly distilled THF. The mixture was cooled to $-78^{\circ} \mathrm{C}$ and then $56.6 \mathrm{~mL}(90 \mathrm{mmol})$ of a $1.6 \mathrm{M} \mathrm{n}-\mathrm{BuLi}$ in hexane solution added dropwise over a period of $30 \mathrm{~min}$. The reaction was stirred for $45 \mathrm{~min}$, and then $5.6 \mathrm{~mL}$ $(85.5 \mathrm{mmol})$ of trimethylene oxide and $10.7 \mathrm{~mL}(85.5 \mathrm{mmol})$ of $\mathrm{BF}_{3} \mathrm{Et}_{2} \mathrm{O}$ were added. The reaction mixture was stirred at $-78^{\circ} \mathrm{C}$ for an additional $2 \mathrm{~h}$ before being quenched with a saturated aqueous solution of $\mathrm{NaHCO}_{3}$. The layers were separated and the aqueous layer extracted three times with $100 \mathrm{~mL}$ of diethyl ether. The combined organic phase was washed with water and brine, and dried over $\mathrm{MgSO}_{4}$, and concentrated in vacuo. The crude product was purified by chromatography through a silica gel column using a gradient elution from hexane:ethyl acetate $=5: 1$ to $3: 1$. The column led to the isolation of $7.2 \mathrm{~g}(57 \%)$ of the desired alcohol $2 \mathbf{b} .{ }^{1} \mathrm{H}$ NMR $\left(300 \mathrm{MHz}, \mathrm{CDCl}_{3}\right) \delta 7.161(\mathrm{~s}, 1 \mathrm{H}), 7.160$ $(\mathrm{s}, 1 \mathrm{H}), 3.71(\mathrm{t}, \mathrm{J}=7.2 \mathrm{~Hz}), 2.45(\mathrm{t}, \mathrm{J}=6.3 \mathrm{~Hz}, 2 \mathrm{H}), 1.97(\mathrm{~s}, 3 \mathrm{H}), 1.82\left(\mathrm{dd}, \mathrm{J}_{1}=7.2 \mathrm{~Hz}, \mathrm{~J}_{2}=\right.$ $6.3 \mathrm{~Hz}, 2 \mathrm{H}), 1.38(\mathrm{~s}, 1 \mathrm{H}) ;{ }^{13} \mathrm{C}$ NMR $\left(75 \mathrm{MHz}, \mathrm{CDCl}_{3}\right) \delta 139.8,139.3,125.0,120.2,62.6$, 32.3, 20.0, 8.3; FT-IR (neat) 3338(s, br); 3073, 2941, 2868; 1545; 1452; 1385; $1046 \mathrm{~cm}^{-1}$; LRMS: $\mathrm{m} / \mathrm{z}$ (EI) 140.0, 127.0, 109.0, 96.0, 78.0, 67.0, 63.0; HRMS: (EI) $\left(\mathrm{M}^{+}\right)$clcd. 140.0837 , found 140.0813 .

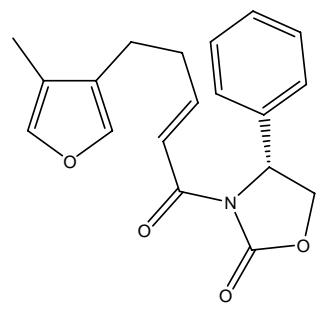

3-[5-(4-Methyl-furan-3-yl)-pent-2-enoyl]-4(R)-phenyl-oxazolidin-2-one: 
To a flame dried three-necked flask containing $6.1 \mathrm{~mL}(70.0 \mathrm{mmol})$ of oxalyl chloride in $140 \mathrm{~mL}$ of $\mathrm{CH}_{2} \mathrm{Cl}_{2}$ at $-78{ }^{\circ} \mathrm{C}$ was added a solution of $9.9 \mathrm{~mL}(140 \mathrm{mmol})$ of DMSO in $10 \mathrm{~mL}$ of $\mathrm{CH}_{2} \mathrm{Cl}_{2}$ over a period of $5 \mathrm{~min}$. The temperature of the reaction was kept below $-65{ }^{\circ} \mathrm{C}$. After 2 minutes, a solution of $4.9 \mathrm{~g}(35.0 \mathrm{mmol})$ of 3-(4-Methylfuran-3-yl)-propan-1-ol (2b) in $10 \mathrm{~mL}$ of $\mathrm{CH}_{2} \mathrm{Cl}_{2}$ was added. The result solution was stirred at $-78^{\circ} \mathrm{C}$ for $15 \mathrm{~min}$ followed by the slow addition of $48.9 \mathrm{~mL}$ (350 mmol) of $\mathrm{NEt}_{3}$ over a 15 min. period. After 30 minutes, the reaction was allowed to slowly warm to room temperature and then stirred for $1 \mathrm{~h}$ at room temperature. The reaction was then quenched with $300 \mathrm{~mL}$ of water. The layers were separated and the aqueous phase extracted three times with $50 \mathrm{~mL}$ of $\mathrm{Et}_{2} \mathrm{O}$. The combined organic layer was washed with water, brine, dried over $\mathrm{MgSO}_{4}$, and then concentrated in vacuo. The crude product was chromatographed through silica gel (hexane: ethyl acetate $=4: 1$ ) in order to afford $8.07 \mathrm{~g}$ $(71 \%)$ of the purified product. ${ }^{1} \mathrm{HNMR}\left(300 \mathrm{MHz}, \mathrm{CDCl}_{3}\right) \delta 7.28-7.41(\mathrm{~m}, 6 \mathrm{H}), 7.03-$ $7.18(\mathrm{~m}, 3 \mathrm{H}), 5.48\left(\mathrm{dd}, \mathrm{J}_{1}=3.9 \mathrm{~Hz}, \mathrm{~J}_{2}=9.0 \mathrm{~Hz}, 1 \mathrm{H}\right), 4.71\left(\mathrm{dd}, \mathrm{J}_{1}=\mathrm{J}_{2}=9.0 \mathrm{~Hz}, 1 \mathrm{H}\right), 4.28$ $\left(\mathrm{dd}, \mathrm{J}_{1}=3.9 \mathrm{~Hz}, \mathrm{~J}_{2}=9 \mathrm{~Hz}, 1 \mathrm{H}\right), 2.49-2.53(\mathrm{~m}, 4 \mathrm{H}), 1.94(\mathrm{~s}, 3 \mathrm{H}) ;{ }^{13} \mathrm{C}$ NMR $(75 \mathrm{MHz}$, $\left.\mathrm{CDCl}_{3}\right) \delta 164.3,154.0,151.0,139.6,139.4,129.4,129.0,126.2,124.3,121.0,119.9,70.2$, 58.0, 32.6, 22.4, 8.3; FT-IR (neat) 2922, 1776, 1686, 1635, 1385, 1354, 1335, 1198, 1045, $711 \mathrm{~cm}^{-1}$; HRMS: (EI) $\left(\mathrm{M}^{+}\right)$clcd. 325.1314, found 325.1307.

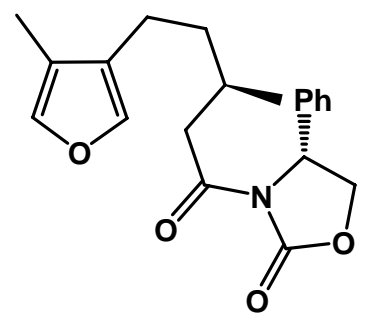

\section{3-[5-(4-Methyl-furan-3-yl)-pentanoyl]-4-phenyl-oxazolidin-2-one (3b):}

To a $100 \mathrm{~mL} 3$-necked flask equipped with thermometer, $11.1 \mathrm{~g}(54.3 \mathrm{mmol})$ of $\mathrm{CuBrMe}_{2} \mathrm{~S}$ was dissolved in $62 \mathrm{~mL}$ of dimethylsulfide and $94 \mathrm{~mL}$ of THF. This mixture was cooled to $-78{ }^{\circ} \mathrm{C}$ and then $23.5 \mathrm{~mL}(70.5 \mathrm{mmol}) \mathrm{MeMgCl}(3.0 \mathrm{M}$ in THF) added dropwise over $20 \mathrm{~min}$. After stirring for stirred $20 \mathrm{~min}$ at $-78^{\circ} \mathrm{C}$, the mixture was warmed to $0{ }^{\circ} \mathrm{C}$ for $20 \mathrm{~min}$ before cooling back to $-78^{\circ} \mathrm{C}$. The cuprate solution was transferred using a cannula to a suspension of $6.74 \mathrm{~g}(21.7 \mathrm{mmol})$ of the enoate made above in a mixed solvent of $55 \mathrm{~mL}$ THF and $28.2 \mathrm{~mL} \mathrm{CH}_{2} \mathrm{Cl}_{2}$ at $-78^{\circ} \mathrm{C}$ over $15 \mathrm{~min}$. The reaction mixture was stirred at $-78{ }^{\circ} \mathrm{C}$ for $1 \mathrm{~h}$, slowly warmed to $-30{ }^{\circ} \mathrm{C}$ over $1 \mathrm{~h}$, stirred at $-30{ }^{\circ} \mathrm{C}$ for $1 \mathrm{~h}$, and then quenched with a saturated $\mathrm{NH}_{4} \mathrm{Cl}$ solution. The aqueous layer was extracted three times with $80 \mathrm{~mL}$ of diethyl ether. The combined organic solution was washed with brine, dried over $\mathrm{MgSO}_{4}$, and concentrated in vacuo. Chromatography of the crude product through silica gel (hexane: ethyl acetate $=4: 1$ ) led to the isolation of $6.5 \mathrm{~g}$ $(92 \%)$ of the pure product. ${ }^{1} \mathrm{H}$ NMR $\left(300 \mathrm{MHz}, \mathrm{CDCl}_{3}\right) \delta 7.39-7.28(\mathrm{~m}, 5 \mathrm{H}), 7.10(\mathrm{~d}, \mathrm{~J}=$ $1.2 \mathrm{~Hz}, 1 \mathrm{H}), 7.07(\mathrm{~s}, 1 \mathrm{H}), 5.40\left(\mathrm{dd}, \mathrm{J}_{1}=3.9 \mathrm{~Hz}, \mathrm{~J}_{2}=8.7 \mathrm{~Hz}, 1 \mathrm{H}\right), 4.63\left(\mathrm{dd}, \mathrm{J}_{1}=\mathrm{J}_{2}=8.7\right.$ $\mathrm{Hz}, 1 \mathrm{H}), 4.20\left(\mathrm{dd}, \mathrm{J}_{1}=3.9 \mathrm{~Hz}, \mathrm{~J}_{2}=8.7 \mathrm{~Hz}, 1 \mathrm{H}\right), 2.90(\mathrm{~d}, \mathrm{~J}=6.0 \mathrm{~Hz}, 2 \mathrm{H}), 2.36-2.23(\mathrm{~m}$, $2 \mathrm{H}), 2.10-2.02(\mathrm{~m}, 1 \mathrm{H}), 1.90(\mathrm{~s}, 3 \mathrm{H}), 1.61-1.52(\mathrm{~m}, 1 \mathrm{H}), 1.44-1.34(\mathrm{~m}, 1 \mathrm{H}), 0.93, \mathrm{~d}, \mathrm{~J}=$ $6.6 \mathrm{~Hz}, 3 \mathrm{H}) ;{ }^{13} \mathrm{C} \mathrm{NMR}\left(75 \mathrm{MHz}, \mathrm{CDCl}_{3}\right) \delta 172.3,154.0,139.6,139.5,139.2,129.4,128.9$, 126.2, 125.5, 120.2, 70.2, 57.9, 42.6, 36.2, 29.8, 21.2, 19.8, 8.3; FT-IR (neat) 3034, 2960, 
2925, 2872, 1781, 1704, 1478, 1494, 1457, 1385, 1322, 1235, 1201, 1138, 1079, 1061, 1044, 1001, 873, 787, 762, 708, 597, $530 \mathrm{~cm}^{-1}$; LRMS: m/z (EI) 341.1,313.1, 246.1, 232.1, 205.0, 195.1, 176.1, 164.1, 153.1, 136.1, 120.1, 109.0,104.0, 96.0, 91.0, 83.0, 69.0; HRMS: (EI) $\left(\mathrm{M}^{+}\right)$clcd: 341.1622 found: 341.1623

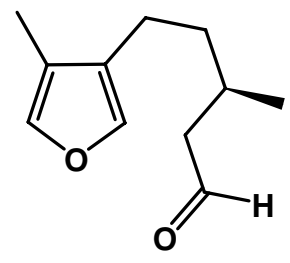

\section{3(R)-Methyl-5-(4-methylfuran-3-yl)-pentanal:}

Imide $3 \mathbf{b}(0.523 \mathrm{~g}, 1.53 \mathrm{mmol})$ was dissolved in $15.3 \mathrm{~mL}$ of $\mathrm{CH}_{2} \mathrm{Cl}_{2}$ and cooled to $-78{ }^{\circ} \mathrm{C}$. To this solution was added dropwise $3.34 \mathrm{~mL}(3.06 \mathrm{mmol})$ of a $1.0 \mathrm{M}$ DIBAL-H in solution over a period of $20 \mathrm{~min}$. The mixture was stirred at $-78^{\circ} \mathrm{C}$ for $30 \mathrm{~min}$ and then quenched with a saturated aqueous Rochelle's salt solution. After the addition of $30 \mathrm{~mL}$ of diethyl ether the reaction mixture was stirred until the upper layer turned clear (over 1 h). The layers were separated and the aqueous phase extracted two times with $30 \mathrm{~mL}$ diethyl ether. The combined organic phase was washed with brine, dried over $\mathrm{MgSO}_{4}$, and concentrated in vacuo. The crude product was flash chromatographed through a silica gel column that had been treated with triethyl amine (pentane/diethyl ether $=4: 1$ ) to give $0.245 \mathrm{~g}(89 \%)$ of the purified aldehyde product. ${ }^{1} \mathrm{H} \mathrm{NMR}(300 \mathrm{MHz}, \mathrm{CDCl} 3) \delta 9.77(\mathrm{t}, \mathrm{J}$ $=2.1 \mathrm{~Hz}, 1 \mathrm{H}), 7.15(\mathrm{~d}, \mathrm{~J}=3.3 \mathrm{~Hz}, 1 \mathrm{H}), 7.14(\mathrm{~d}, \mathrm{~J}=4.2 \mathrm{~Hz}, 1 \mathrm{H}), 2.5-2.3(\mathrm{~m}, 4 \mathrm{H}), 2.13(\mathrm{o}, \mathrm{J}=$ $6.6 \mathrm{~Hz}, 1 \mathrm{H}), 1.97(\mathrm{~s}, 3 \mathrm{H}), 1.66-1.42(\mathrm{~m}, 4 \mathrm{H}), 1.05(\mathrm{~d}, \mathrm{~J}=6.6 \mathrm{~Hz}, 3 \mathrm{H}) ;{ }^{13} \mathrm{C} \mathrm{NMR}(75 \mathrm{MHz}$, $\left.\mathrm{CDCl}_{3}\right) \delta 202.9,139.8,139.2,125.2,120.1,51.2,36.6,28.1,21.2,20.1,8.3$; FT-IR (neat) 2929, 2858, 2721, 1723, 1501, 1459, 1382, 1159, 1065, 1023, 873, 783, 727, $600 \mathrm{~cm}^{-1}$; LRMS: m/z (EI); (180.2, 152.2, 136.1, 123.1, 109.1, 96.1, 86.0, 84.0, 67.1) HRMS: (EI) $\left(\mathrm{M}^{+}\right)$clcd.180.115, found 180.1154

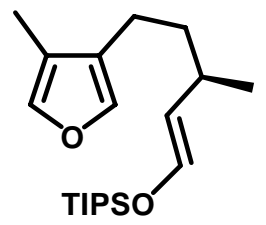

\section{(5-(4-Furan-3-yl)-3(R)-methylpent-1-enyloxy)triisopropyl-silane (4b):}

The aldehyde made in the previous experiment $(0.51 \mathrm{~g}, 2.8 \mathrm{mmol})$ and $1.2 \mathrm{~mL}$ of $\mathrm{NEt}_{3}$ were dissolved in $10 \mathrm{~mL}$ of $\mathrm{CH}_{2} \mathrm{Cl}_{2}$ and cooled to $0{ }^{\circ} \mathrm{C}$. To this solution was added dropwise $0.93 \mathrm{~mL}$ of TIPSOTf. The resulting solution was stirred overnight at room temperature. The reaction mixture was quenched with $10 \mathrm{~mL}$ water, the layers separated, and then extracted three times with $15 \mathrm{~mL}$ of $\mathrm{Et}_{2} \mathrm{O}$. The combined organic phase was washed with brine, dried over $\mathrm{MgSO}_{4}$, and concentrated in vacuo. The crude product was chromatographed through a silica gel column (petane/diethyl ether $=4: 1$ ) to afford $0.75 \mathrm{~g}$ $(79 \%)$ of the desired product. ${ }^{1} \mathrm{H}$ NMR $\left(300 \mathrm{MHz}, \mathrm{CDCl}_{3}\right) \delta 7.12(\mathrm{~s}, 2 \mathrm{H}), 6.27(\mathrm{~d}, \mathrm{~J}=5.7$ $\mathrm{Hz}, 1 \mathrm{H}), 4.21\left(\mathrm{dd}, \mathrm{J}_{1}=5.7 \mathrm{~Hz}, \mathrm{~J}_{2}=7.0 \mathrm{~Hz}, 1 \mathrm{H}\right), 2.81-2.73(\mathrm{~m}, 1 \mathrm{H}), 2.37-2.24(\mathrm{~m}, 2 \mathrm{H})$, 
$1.94(\mathrm{~s}, 3 \mathrm{H}), 1.27-0.95(\mathrm{~m}, 21 \mathrm{H}), 0.99(\mathrm{~d}, \mathrm{~J}=6.6,3 \mathrm{H}) ;{ }^{13} \mathrm{C} \mathrm{NMR}\left(75 \mathrm{MHz}, \mathrm{CDCl}_{3}\right) \delta$ 139.4, $139.0,138.6,126.2,120.2,115.8,37.5,28.7,21.8,21.4,18.0,12.2,8.2$; FT-IR (neat)3018, 2944, 2866, 1654, 1462, 1404, 1384, 1251, 1181, 1142, 1104, 1063, 1049, 1006, 883, 781, 750, 684, 668, $641 \mathrm{~cm}^{-1} \cdot$ : MS: LRMS: m/z (EI); (336.2, 293.2, 240.2, 227.2, 197.1, 163.1, 145.1, 131.1, 115.1, 103.0, 95.0, 87.0, 75.0, 59.0) HRMS: (EI) (M $\left.{ }^{+}\right)$ clcd.336.2485, found 336.2486

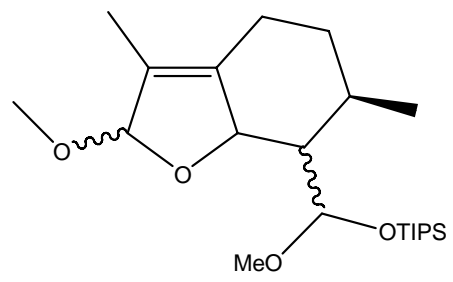

\section{2,9,9-Trimethoxy-3-methyl-6(R)-methyl-4,5,6,6a,7,8,9,10-octahydro-2H-1-oxa- cyclopenta naphthalene (5b):}

The silyl enol ether $(0.968 \mathrm{~g}, 3 \mathrm{mmol})$ was mixed with $3.02 \mathrm{~g}(28.4 \mathrm{~mol})$ of $\mathrm{LiClO}_{4}, 2.07$ $\mathrm{mL}(18 \mathrm{mmol})$ of 2,6-lutidine, $60 \mathrm{~mL}$ of $\mathrm{CH}_{2} \mathrm{Cl}_{2}, 15 \mathrm{~mL}$ of $\mathrm{MeOH}$. The reaction flask was fitted with an RVC anode and carbon cathode, and then a constant current of $18 \mathrm{~mA}$ passed through reaction until $2.08 \mathrm{~F} /$ mole of charge was consumed. At that point, $3.99 \mathrm{~g}$ (21 mmol) of $\mathrm{TsOH}$ was added. The reaction system changed color quickly to dark brown/black. Water was added, the layers separated, and the aqueous phase was extracted three times with $20 \mathrm{~m} / \mathrm{L}$ of $\mathrm{CH}_{2} \mathrm{Cl}_{2}$. NMR showed most of the product was still the 2,5dihydrofuran methyl silyl ketal. The rest was furanyl methl silyl ketal. $0.1 \mathrm{~N} \mathrm{HCl}$ was used to titrate 2,6-lutidine. Solvent was removed under reduced pressure. The residue was passed throught a silica gel column with hexane: diethylether (10:1). $0.36 \mathrm{~g}$ product was obtained. Yield: $30 \%$.

HNMR major product: $\left(300 \mathrm{MHz}, \mathrm{CDCl}_{3}\right) \delta 7.07(\mathrm{~s}, 1 \mathrm{H}), 5.12$, (d, J=1.8, $\left.1 \mathrm{H}\right), 3.23(\mathrm{~s}, 3 \mathrm{H})$ $(2.59-2.64, \mathrm{~m}, 2 \mathrm{H}), 2.42-2.30(\mathrm{~m}, 1 \mathrm{H}), 2.28(\mathrm{t}, \mathrm{J}=2.4 \mathrm{~Hz}, 2 \mathrm{H}), 1.91(\mathrm{~s}, 3 \mathrm{H}), 1.42(\mathrm{~s}, 2 \mathrm{H})$, 1.15-1.00(m, 24H); IR (neat) 2943.7, 2924.9, 2866.5, 1773.9, 1653.9, 1462.6, 1383.5, $1366.8,1330.3,1255.5,1192.8,1132.1,1097.0,1067.4,994.2,882.6,683.6 \mathrm{~cm}^{-1}$

MS HRMS (EI) (M+) calc 398.2853, found 398.2855

With the reaction clearly being problematic, attention was turned to the ketene acetal based cyclizations.

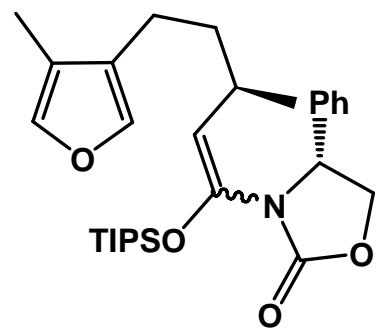




\section{3-[3(R)-Methyl-5-(4-methyl-furan-3-yl)-1-triisopropylsilanyloxy-pent-1-enyl]-4(R)- phenyl-oxazolidin-2-one (6b):}

In a $250 \mathrm{~mL}$ flame dried flask, $4.65 \mathrm{~g}(13.6 \mathrm{mmol})$ of imide $3 \mathbf{b}$ was dissolved in 70 $\mathrm{mL}$ of THF and cooled to $-78^{\circ} \mathrm{C}$. To this mixture was added $15.0 \mathrm{~mL}$ of a $1.0 \mathrm{M}$ NaHMDS in THF solution over a period of $30 \mathrm{~min}$. The solution was stirred at $-78^{\circ} \mathrm{C}$ for $2 \mathrm{~h}$, and then $4.52 \mathrm{~mL}(16.7 \mathrm{mmol})$ of TIPSOTf added dropwise. The reaction was stirred for an additional $-78{ }^{\circ} \mathrm{C}$ for $2 \mathrm{~h}$. The solvent was removed under reduced pressure and then $100 \mathrm{~mL}$ of diethyl ether added, the reaction filtered through a celite pad and the filtrate concentrated again. The residue was purified by chromatography through a silica gel column neutralized with triethylamine (hexane/ethyl acetate $=8: 1$ ) to afford $6.4 \mathrm{~g}$ $(94 \%)$ of the desired ketene acetal product. ${ }^{1} \mathrm{H}$ NMR $\left(300 \mathrm{MHz}, \mathrm{CDCl}_{3}\right) \delta 7.39-7.28(\mathrm{~m}$, $5 \mathrm{H}), 7.11(\mathrm{~s}, 1 \mathrm{H}), 7.05(\mathrm{~s}, 1 \mathrm{H}), 5.00\left(\mathrm{dd}, \mathrm{J}_{1}=3.9 \mathrm{~Hz}, \mathrm{~J}_{2}=8.7 \mathrm{~Hz}, 1 \mathrm{H}\right), 4.63\left(\mathrm{dd}, \mathrm{J}_{1}=\mathrm{J}_{2}=\right.$ $8.7 \mathrm{~Hz}, 1 \mathrm{H}), 4.28\left(\mathrm{dd}, \mathrm{J}_{1}=3.9 \mathrm{~Hz}, \mathrm{~J}_{2}=8.7 \mathrm{~Hz}, 1 \mathrm{H}\right), 4.21(\mathrm{~d}, \mathrm{~J}=9.6 \mathrm{~Hz}, 1 \mathrm{H}), 2.41-2.33$ $(\mathrm{m}, 1 \mathrm{H}), 2.31-2.24(\mathrm{~m}, 2 \mathrm{H}), 1.89(\mathrm{~s}, 3 \mathrm{H}), 1.43\left(\mathrm{dd}, \mathrm{J}_{1}=7.5 \mathrm{~Hz}, \mathrm{~J}_{2}=13.8 \mathrm{~Hz}, 2 \mathrm{H}\right), 1.11-$ $1.02(\mathrm{~m}, 21 \mathrm{H}), 0.61(\mathrm{~d}, \mathrm{~J}=6.9 \mathrm{~Hz}, 3 \mathrm{H}) ;{ }^{13} \mathrm{C}$ NMR $\left(75 \mathrm{MHz}, \mathrm{CDCl}_{3}\right) \delta 155.5,139.5,139.0$, 137.9, 136.8, 129.0, 127.5, 125.6, 120.2, 115.2, 69.3, 60.4, 36.4, 29.9, 21.4, 20.2, 18.0, 17.9, 13.4, 8.2; FT-IR (neat) 3093.3, 3044.4, 2946, 2866, 1958, 1768, 1678, 1458, 1390, 1342, 1281, 1199, 1118, 1048, 883, 783, 716, $687 \mathrm{~cm}^{-1}$; LRMS: m/z $\left(\mathrm{EI}^{+}\right)$497.4, 469.4, 454.3, 320.3, 309.3, 276.2, 232.3, 203.2, 131.1, 103.1, 75.0; HRMS: (EI $\left.{ }^{+}\right)$clcd. 497.2961, found 497.2948 .

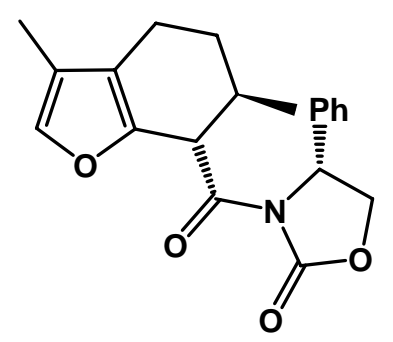

\section{3-(3,6(R)-Dimethyl-4,5,6,7-tetrahydro-benzofuran-7(S)-carbonyl)-4(R)-phenyl- oxazolidin-2-one (7b)}

In a three necked flask, $3.0 \mathrm{~g}(6.0 \mathrm{mmol})$ of N,O-ketene acetal $\mathbf{6 b}, 6.76 \mathrm{~g}(22.4$ $\mathrm{mmol})$ of $\mathrm{Et}_{4} \mathrm{NOTs}$ and $3.86 \mathrm{~g}(36.0 \mathrm{mmol})$ of 2,6-lutidine was dissolved in a mixed solvent of $192 \mathrm{~mL} \mathrm{CH}_{2} \mathrm{Cl}_{2}$ and $48 \mathrm{~mL}$ methanol. A constant current of $28 \mathrm{~mA}$ was passed through the cell until a total of $2.4 \mathrm{~F} / \mathrm{mol}$ of charge was consumed. The reaction was

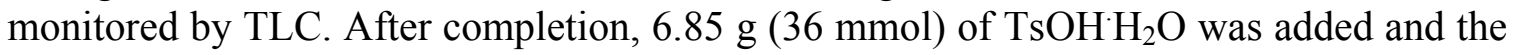
mixture stirred overnight. In the morning, $3 \mathrm{~mL}$ of $\mathrm{NEt}_{3}$ was added and the solvent removed in vacuo. Diethyl ether $(100 \mathrm{~mL})$ was added and the reaction filtered through a celite pad and then concentrated. The crude product was then chromatographed through a silica gel column with hexane/ethyl acetate (5:1) to obtain $1.32 \mathrm{~g}(65 \%)$ of the desired product. An NMR yield for the reaction obtained in a fashion identical to that described above for 10a was found to be $90 \% .{ }^{1} \mathrm{H}$ NMR $\left(300 \mathrm{MHz}, \mathrm{CDCl}_{3}\right) \delta 7.40-7.28(\mathrm{~m}, 5 \mathrm{H})$, $7.05(\mathrm{t}, \mathrm{J}=3.9 \mathrm{~Hz}, 1 \mathrm{H}), 5.47\left(\mathrm{dd}, \mathrm{J}_{1}=3.9 \mathrm{~Hz}, \mathrm{~J}_{2}=9 \mathrm{~Hz}, 1 \mathrm{H}\right), 4.74(\mathrm{~d}, \mathrm{~J}=5.1 \mathrm{~Hz}, 1 \mathrm{H})$, $4.72(\mathrm{t}, \mathrm{J}=9.0 \mathrm{~Hz}, 1 \mathrm{H}), 4.29\left(\mathrm{dd}, \mathrm{J}_{1}=3.9 \mathrm{~Hz}, \mathrm{~J}_{2}=9.0 \mathrm{~Hz}, 1 \mathrm{H}\right), 2.31\left(\mathrm{dt}, \mathrm{J}_{1}=1.5 \mathrm{~Hz}, \mathrm{~J}_{2}=\right.$ $6.3 \mathrm{~Hz}, 2 \mathrm{H}), 2.32-2.21(\mathrm{~m}, 1 \mathrm{H}), 1.88(\mathrm{~s}, 3 \mathrm{H}), 1.60\left(\mathrm{ddd}, \mathrm{J}_{1}=3.3 \mathrm{~Hz}, \mathrm{~J}_{2}=7.2 \mathrm{~Hz}, \mathrm{~J}_{3}=\right.$ 
$13.5 \mathrm{~Hz}, 1 \mathrm{H}), 1.49$ (hd, $\left.\mathrm{J}_{1}=6 \mathrm{~Hz}, \mathrm{~J}_{2}=7.5 \mathrm{~Hz}, 1 \mathrm{H}\right), 1.02(\mathrm{~d}, \mathrm{~J}=9.9 \mathrm{~Hz}, 3 \mathrm{H}) ;{ }^{13} \mathrm{C}$ NMR $\left(75 \mathrm{MHz}, \mathrm{CDCl}_{3}\right) \delta 172.4,153.8,146.3,139.5,138.4,129.4,128.9,126.3,119.7,70.1$, 58.2, 46.2, 33.3, 28.1, 19.2, 18.3, 8.3; FT-IR (neat) 2926, 1780, 1705, 1457, 1394, 1366, 1325, 1237, 1199, 1099, 1042, $700 \mathrm{~cm}^{-1}$; LRMS: $\mathrm{m} / \mathrm{z}$ (EI) 339.1, 176.1, 149.1, 131.2; HRMS: (EI) $\left(\mathrm{M}^{+}\right)$calcd 339.1471, found 339.1483.

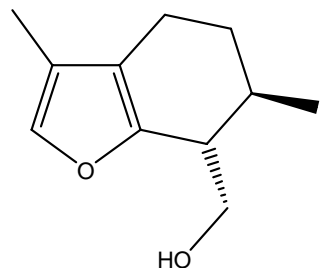

\section{(3,6(R)-Dimethyl-4,5,6,7-tetrahydro-benzofuran-7-yl)-methanol:}

In a $100 \mathrm{~mL}$ flamed dried flask, compound $7 \mathbf{b}(3.1 \mathrm{~g}, 9.1 \mathrm{mmol})$ was dissolved in $52 \mathrm{~mL}$ of anhydrous diethyl ether. To this solution was added $1.48 \mathrm{~mL}(30.8 \mathrm{mmol})$ of methanol. The solution was cooled to $0^{\circ} \mathrm{C}$ with ice-water bath and $18.3 \mathrm{~mL}(36.6 \mathrm{mmol})$ of a $2.0 \mathrm{M} \mathrm{LiBH}_{4} \mathrm{THF}$ solution added dropwise over $45 \mathrm{~min}$. The mixture was stirred at 0 ${ }^{\circ} \mathrm{C}$ for $2 \mathrm{~h}$ and then quenched with a saturated aqueous solution of $\mathrm{NaHCO}_{3}$. They layers were separated and the aqueous layer extracted three times with $50 \mathrm{~mL}$ of diethyl ether. The combined organic layer was washed with brine, dried over $\mathrm{MgSO}_{4}$, and concentrated in vacuo. The crude product was chromatographed through a silica gel column (pentane/diethyl ether $=4: 1)$ to afford $1.49 \mathrm{~g}(91 \%)$ of the desired alcohol. ${ }^{1} \mathrm{H}$ NMR $\left(300 \mathrm{MHz}, \mathrm{CDCl}_{3}\right) \delta 7.08(\mathrm{~d}, \mathrm{~J}=1.2 \mathrm{~Hz}, 1 \mathrm{H}), 3.96\left(\mathrm{ddd}, \mathrm{J}_{1}=4.5 \mathrm{~Hz}, \mathrm{~J}_{2}=7.8 \mathrm{~Hz}, \mathrm{~J}_{3}=\right.$ $12.0 \mathrm{~Hz}, 1 \mathrm{H}), 2.73$ (ddd, $\left.\mathrm{J}_{1}=5.4 \mathrm{~Hz}, \mathrm{~J}_{2}=5.7 \mathrm{~Hz}, \mathrm{~J}_{3}=8.4 \mathrm{~Hz}, 1 \mathrm{H}\right), 2.48-2.36(\mathrm{~m}, 1 \mathrm{H})$, 2.36-2.30 (m, 2H), $1.92(\mathrm{~s}, 3 \mathrm{H}), 1.87-1.78(\mathrm{~m}, 3 \mathrm{H}), 1.55-1.46(\mathrm{~m}, 2 \mathrm{H}), 1.08(\mathrm{~d}, \mathrm{~J}=6.6 \mathrm{~Hz}$, $3 \mathrm{H} ;{ }^{13} \mathrm{C}$ NMR $\left(75 \mathrm{MHz}, \mathrm{CDCl}_{3}\right) \delta 151.6,137.9,119.7,100.2,63.9,44.7,30.7,30.6,19.8$, 19.4, 8.3; FT-IR 3368.1, 2955.4, 2924.4, 2847.9, 1640,4, 1563.3, 1437.6, 1458.0, 1417.9, 1379.2, 1310.6, 1222.1, 1151.2, 1132.8, 1100.2, 1059.9, 1035.1, 1017.9, 987.6, 949.6, 889.7, 877.2, 847.6, 817.8, 735.8; LRMS m/z (EI) 180.1, 149.1, 134.1, 131.1, 119.1, 105.1, 93.1, 79.0, 77.0, 69.0; HRMS (EI) $\left(\mathrm{M}^{+}\right)$clcd 180.115 found 180.1156

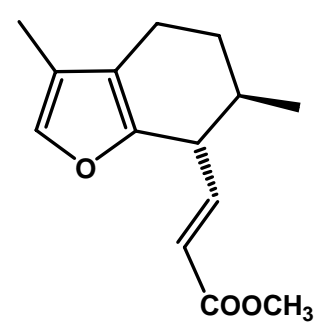

\section{3-(3,6(R)-Dimethyl-4,5,6,7-tetrahydro-benzofuran-7-yl)-acrylic acid methyl ester:}

In a $100 \mathrm{~mL}$ flame dried flask, the alcohol made $(1.64 \mathrm{~g} / 9.1 \mathrm{mmol})$ above was dissolved in $54.6 \mathrm{~mL}$ of $\mathrm{CH}_{2} \mathrm{Cl}_{2}$ along with $6.34 \mathrm{~mL}$ ( $45.5 \mathrm{mmol}$ ) of triethylamine. The solution was cooled to $0{ }^{\circ} \mathrm{C}$ and $7.24 \mathrm{~g}(45.5 \mathrm{mmol})$ of $\mathrm{Pyr}^{-} \mathrm{SO}_{3}$ added over a period of 5 
min. After being stirred at $0^{\circ} \mathrm{C}$ for $10 \mathrm{~min}$, the solution was allowed to warm to room temperature and kept at room temperature for an additional $50 \mathrm{~min}$. The resulted red solution was quenched with $100 \mathrm{~mL}$ of ice water. The aqueous layer was extracted three times with $50 \mathrm{~mL}$ of pentane/diethyl ether (1:1). The combined solution was washed with brine and concentrated to approximately $10 \mathrm{~mL}$ total volume.

In a $250 \mathrm{~mL}$ flame dried flask, $0.728 \mathrm{~g}(18.2 \mathrm{mmol})$ of $60 \% \mathrm{NaH}$ in oil was suspended in $10 \mathrm{~mL}$ of pentane. The solvent was removed with a syring in order to was away the oil. This operation was repeated before adding $91 \mathrm{~mL}$ of dry THF to the flask and cooling the solution to $0{ }^{\circ} \mathrm{C}$. To this flask was added $4.02 \mathrm{~g}(19.1 \mathrm{mmol})$ of (EtO) $)_{2} \mathrm{POCH}_{2} \mathrm{CO}_{2} \mathrm{CH}_{3}$ over a period of $10 \mathrm{~min}$. The mixture was allowed to warm to room temperature for $1 \mathrm{~h}$ and then cooled back to $0{ }^{\circ} \mathrm{C}$. The crude aldehyde from above was added in a dropwise fashion. After being stirred at $0{ }^{\circ} \mathrm{C}$ for $2 \mathrm{~h}$, the reaction mixture was quenched with a saturated aqueous solution of $\mathrm{NH}_{4} \mathrm{Cl}$. The layers were separated and the aqueous phase extracted two times with $30 \mathrm{~mL}$ of pentane/diethyl ether (10:1). The combined organic solution was concentrated in vacuo and then chromatographed through a silica gel column (eluant: pentane:diethyl ether=10:1 ) to yield $1.63 \mathrm{~g}(77 \%)$ of the purified product. ${ }^{1} \mathrm{H}$ NMR $(300 \mathrm{MHz}, \mathrm{CDCl} 3) \delta 7.07(\mathrm{~d}, \mathrm{~J}=0.9 \mathrm{~Hz}, 1 \mathrm{H}), 6.83\left(\mathrm{dd}, \mathrm{J}_{1}=0\right.$ $\left.=8.7 \mathrm{~Hz}, \mathrm{~J}_{3}=15.3 \mathrm{~Hz}, 1 \mathrm{H}\right), 5.93\left(\mathrm{dd}, \mathrm{J}_{1}=0.6 \mathrm{~Hz}, \mathrm{~J}_{2}=15.6 \mathrm{~Hz}, 1 \mathrm{H}\right), 3.73(\mathrm{~s}, 3 \mathrm{H}), 3.11(\mathrm{t}$, $\mathrm{J}=8.1 \mathrm{~Hz}, 1 \mathrm{H}), 2.39-2.34(\mathrm{~m}, 2 \mathrm{H}), 1.92(\mathrm{~s}, 3 \mathrm{H}), 1.92-1.76(\mathrm{~m}, 2 \mathrm{H}), 1.54-1.43(\mathrm{~m}, 1 \mathrm{H})$, $1.04(\mathrm{~d}, \mathrm{~J}=9.6 \mathrm{~Hz}, 3 \mathrm{H}) ;{ }^{13} \mathrm{C} \mathrm{NMR}\left(75 \mathrm{MHz}, \mathrm{CDCl}_{3}\right) \delta 167.0,149.3,148.9,138.5,123.3$, 119.8, 119.0, 51.7, 34.4, 30.0, 19.5, 19.7, 19.4, 8.3; FT-IR (neat) 2953, 2910, 2851, 1720, $1715,1658,2651,1556,1440,1384,1337,1319,1257,1185,1158,1120,983,908,855$, 764, 736, 724, $716 \mathrm{~cm}^{-1}$; LRMS: m/z (EI) 233.9, 218.9, 202.9, 191.9, 175.0, 158.9, 144.9, 132.9, 105.0, 91.0, 77.0, 65.0 ; HRMS: (EI) (M $\mathrm{M}^{+}$) clcd 234.1256, found 234.1243

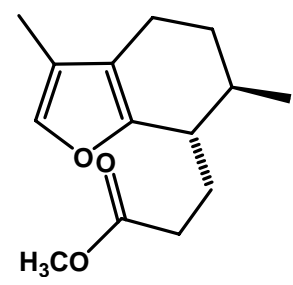

3-(3,6(R)-Dimethyl-4,5,6,7-tetrahydro-benzofuran-7(R)-yl)-propionic acid methyl ester (8b):

The enoate made in the previous step $(1.02 \mathrm{~g}, 4.19 \mathrm{mmol})$ and $\mathrm{NiCl}_{2} \cdot 6 \mathrm{H}_{2} \mathrm{O}(0.094$ g, $0.419 \mathrm{mmol}$ ) were dissolved in $13.4 \mathrm{~mL} \mathrm{MeOH}$. The mixture was cooled to $0^{\circ} \mathrm{C}$ and $0.317 \mathrm{~g}(8.38 \mathrm{mmol})$ of $\mathrm{NaBH}_{4}$ added in portions over a period of $5 \mathrm{~min}$. The solution turned black during the addition. The reaction mixture was stirred at $0^{\circ} \mathrm{C}$ for $1 \mathrm{~h}$ and then quenched with $20 \mathrm{~mL}$ of a saturated $\mathrm{NaHCO}_{3}$ in water solution. After filtration through a pad of celite, the mixture was extracted three times with $50 \mathrm{~mL}$ of diethyl ether. The combined organic phase was washed with brine and dried over $\mathrm{MgSO}_{4}$. The solution was concentrated by distillation (important). After most of solvent had been removed, the remaining solvent was removed by briefly putting the residue on a rotary evaporator. The reactiona afforded $1.00 \mathrm{~g}(97 \%)$ of a product that required no further purification. ${ }^{1} \mathrm{H}$ NMR $\left(300 \mathrm{MHz}, \mathrm{CDCl}_{3}\right) \delta 7.04(\mathrm{~s}, 1 \mathrm{H}), 3.66(\mathrm{~s}, 3 \mathrm{H}), 2.54\left(\mathrm{ddd}, \mathrm{J}_{1}=6.0 \mathrm{~Hz}, \mathrm{~J}_{2}=10.2 \mathrm{~Hz}\right.$, 
$\left.\mathrm{J}_{3}=16.2 \mathrm{~Hz}, 1 \mathrm{H}\right), 2.41-2.27(\mathrm{~m}, 4 \mathrm{H}), 2.14-2.03(\mathrm{~m}, 1 \mathrm{H}), 1.90(\mathrm{~s}, 3 \mathrm{H}), 1.88-1.77(\mathrm{~m}, 2 \mathrm{H})$, $1.74-1.66(\mathrm{~m}, 1 \mathrm{H}), 1.52-1.34(\mathrm{~m}, 1 \mathrm{H}), 1.03(\mathrm{~d}, \mathrm{~J}=6.9 \mathrm{~Hz}, 3 \mathrm{H}) ;{ }^{13} \mathrm{C} \mathrm{NMR}(75 \mathrm{MHz}$, $\left.\mathrm{CDCl}_{3}\right) \delta 174.8,150.8,137.5,119.4,118.3,52.0,41.3,33.7,32.1,29.9,27.5,19.4,8.3$; FT-IR 2953.3, 2927.8, 2872.2, 1957.5, 1783.5, 1737.9, 1637.9, 1561.0, 1437.5, 1380.9, 1316.2, 1253.5, 1196.8, 1171.8, 1130.1, 1093.6, 1012.7, 986.4, 956.1, 887.3, 737.6; LRMS: m/z (EI) 235.9, 204.9, 193.9, 176.1, 162.0, 149.0, 135.0, 119.0, 105.0, 91.0, 76.9; HRMS: (EI) $\left(\mathrm{M}^{+}\right)$clcd 236.1412, found 236.1394.

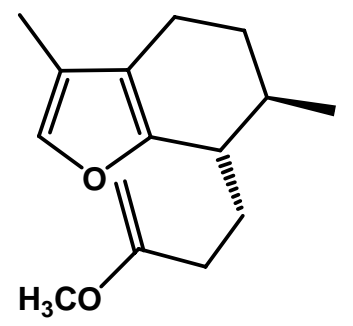

7(S)-(3-Methoxy-but-3-enyl)-3,6(R)-dimethyl-4,5,6,7-tetrahydro-benzofuran (9b):

In a flame dried $50 \mathrm{~mL}$ round bottom flask, ester $8 \mathbf{b}(0.55 \mathrm{~g}, 2.5 \mathrm{mmol})$ was mixed with $12.25 \mathrm{~g}$ of an $8.5 \%$ solution of $\mathrm{Cp}_{2} \mathrm{TiMe}_{2}$ in toluene and stirred at $60 \sim 65{ }^{\circ} \mathrm{C}$ overnight under an Argon atmosphere. The reaction was then cooled to room temperature and then quenched with $100 \mathrm{~mL}$ of pentane in order to precipitate the excess $\mathrm{Cp}_{2} \mathrm{TiMe}_{2}$. The resulting mixture was filtered through a pad of celite and the filtrate concentrated by distillation. The residue was chromatographed through an alumina column (Activity III) to afford $0.46 \mathrm{~g}(80 \%)$ of the desired enol ether $9 \mathrm{~b} .{ }^{1} \mathrm{H}$ NMR $\left(300 \mathrm{MHz}, \mathrm{CDCl}_{3}\right) \delta 7.11(\mathrm{t}$, $\mathrm{J}=0.9 \mathrm{~Hz}, 1 \mathrm{H}), 3.88(\mathrm{~d}, \mathrm{~J}=2.7 \mathrm{~Hz}, 2 \mathrm{H}), 3.50(\mathrm{~s}, 3 \mathrm{H}), 2.30(\mathrm{t}, \mathrm{J}=4.5 \mathrm{~Hz}, 2 \mathrm{H}), 2.34-2.20$ $(\mathrm{m}, 2 \mathrm{H}), 2.13-2.04(\mathrm{~m}, 1 \mathrm{H}), 1.88(\mathrm{~s}, 3 \mathrm{H}), 1.88-1.72(\mathrm{~m}, 4 \mathrm{H}), 1.49-1.41(\mathrm{~m}, 1 \mathrm{H}), 1.01(\mathrm{~d}, \mathrm{~J}$ $=6.9 \mathrm{~Hz}, 3 \mathrm{H}) ;{ }^{13} \mathrm{C} \mathrm{NMR}\left(75 \mathrm{MHz}, \mathrm{CDCl}_{3}\right) \delta 164.5,153.4,137.4,119.2,117.4,79.9,54.3$, 42.0, 33.2, 32.5, 30.2, 29.4, 18.8, 18.6, 7.5; FT-IR (neat) 2924, 1779, 1763, 1715, 1450, 1377, 1272, 1232, 1130, 1092, 993, 798, $736 \mathrm{~cm}^{-1}$; LRMS: m/z (EI) 234.1, 218.2, 191.1, 178.1, 165.1,161.1, 147.1, 125.0, 123.0, 99.0, 84.0; HRMS: (EI) $\left(\mathrm{M}^{+}\right)$clcd 234.1620, found 234.1557.

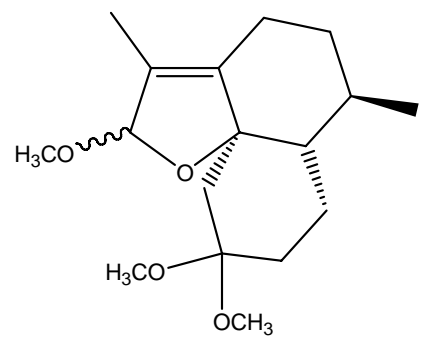

\section{2,9,9-Trimethoxy-3,6(R)-dimethyl-4,5,6,6a,7,8,9,10-octahydro-2H-1-oxa- cyclopenta[d] naphthalene (10b):}

In a $25 \mathrm{~mL}$ three neck round bottom flask, electrolysis substrate $9 \mathbf{b}(100 \mathrm{mg}, 0.43$ mmol) was dissolved in $13.7 \mathrm{~mL}$ of $\mathrm{CH}_{2} \mathrm{Cl}_{2}$ and $3.4 \mathrm{~mL}$ of methanol together with 275 $\mathrm{mg}(2.56 \mathrm{mmol})$ of 2,6-lutidine and $170 \mathrm{mg}(1.6 \mathrm{mmol})$ of $\mathrm{LiClO}_{4}$. The flask was equipped with a RVC anode $(6 \mathrm{~mm} \times 6 \mathrm{~mm} \times 6 \mathrm{~mm})$ and a graphite rod cathode. A constant 
current of $8 \mathrm{~mA}$ was then passed through the solution until $2 \mathrm{~F} / \mathrm{mole}$ of charge was consumed and TLC showed no remaining starting material. The mixture was washed with water, the layers speparated, and the aqueous layer extracted three times with $30 \mathrm{~mL}$ of diethyl ether. To the combined organic layer was added $114 \mathrm{mg}(0.43 \mathrm{mmol})$ of 2,4dibromoanisole as internal NMR standard. The NMR yield for the reaction was found to be $90 \%$. The solution was titrated with $24 \mathrm{~mL}$ of a $0.1 \mathrm{~N} \mathrm{HCl}$ in water solution. The layers were separated and the organic phase was washed with brine, dried over $\mathrm{MgSO}_{4}$ and concentrated in vacuo. The product was chromatographed through a silica gel column with pentane/diethyl ether $(2: 1)$ to afford $88.3 \mathrm{mg}(70 \%)$ of the tricyclic product as a mixture of two stereoisomers. ${ }^{1} \mathrm{H}$ NMR $\left(300 \mathrm{MHz}, \mathrm{CDCl}_{3}\right) \delta 5.61(\mathrm{~s}, 0.37 \mathrm{H}), 5.33(\mathrm{~s}$, $0.63 \mathrm{H}), 3.50(\mathrm{~s}, 1.89 \mathrm{H}), 3.31(\mathrm{~s}, 1.11 \mathrm{H}), 3.24(\mathrm{~s}, 1.89 \mathrm{H}), 3.23(\mathrm{~s}, 1.11 \mathrm{H}), 3.19(\mathrm{~s}, 1.11 \mathrm{H})$, $3.18(\mathrm{~s}, 1.89 \mathrm{H}), 2.48-2.40(\mathrm{~m}, 1 \mathrm{H}), 2.05-1.67(\mathrm{~m}, 8 \mathrm{H}), 1.65(\mathrm{~s}, 1.89 \mathrm{H}), 1.62(\mathrm{~s}, 1.11 \mathrm{H})$, $1.44-1.24(\mathrm{~m}, 2 \mathrm{H}), 1.03\left(\mathrm{dd}, \mathrm{J}_{1}=3.6 \mathrm{~Hz}, \mathrm{~J}_{2}=12.3 \mathrm{~Hz} ; 1.26 \mathrm{H}\right), 0.95\left(\mathrm{dd}, \mathrm{J}_{1}=4.2 \mathrm{~Hz}, \mathrm{~J}_{2}=\right.$ $12.3 \mathrm{~Hz} ; 0.74 \mathrm{H}), 0.88(\mathrm{~d}, \mathrm{~J}=6.6 \mathrm{~Hz}, 3 \mathrm{H}) ;{ }^{13} \mathrm{C} \mathrm{NMR}\left(75 \mathrm{MHz}, \mathrm{CDCl}_{3}\right)$ major product: $\delta$ $142.3,123.8,111.6,100.3,89.7,60.0,50.6,48.1,17.3,37.2,36.0,30.5,27.5,23.6,20.3$, 19.2, 9.8; minor product: $\delta 142.6,123.6,110.3,100.4,89.2,52.7,50.2,48.4,47.3,37.0$, 36.2, 30.7, 27.4, 23.7, 20.2, 29.2, 9.6; FT-IR (neat) $\mathrm{cm}^{-1}$ 2943, 2852, 2826, 1708, 1446, 1372, 1316, 1275, 1180, 1154, 1106, 1054, 1014, 989, 942, 925, 831, 810, 773, 685; LRMS: $\mathrm{m} / \mathrm{z}$ (EI) 296.2, 281.2, 265.2, 249.1, 233.1, 193.1, 180.1, 165.1, 161.1, 159.1, 133.1, 115.1, 105.1, 101.0, 97.0, 91.0, 88.0, 85.0, 79.0, 77.0; HRMS: (EI) $\left(\mathrm{M}^{+}\right)$, clcd: 296.1988, found 296.2007. 


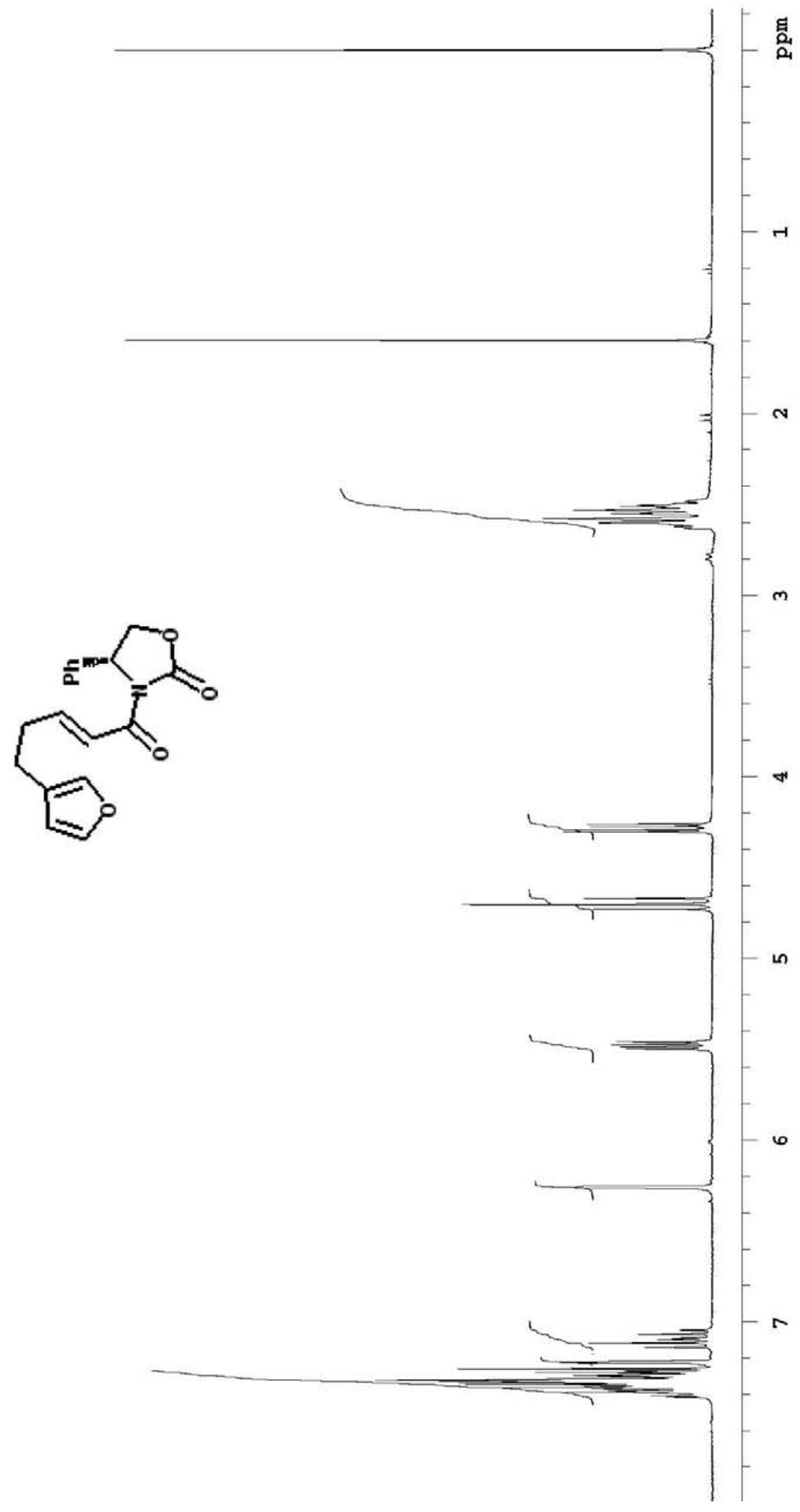

S-18 

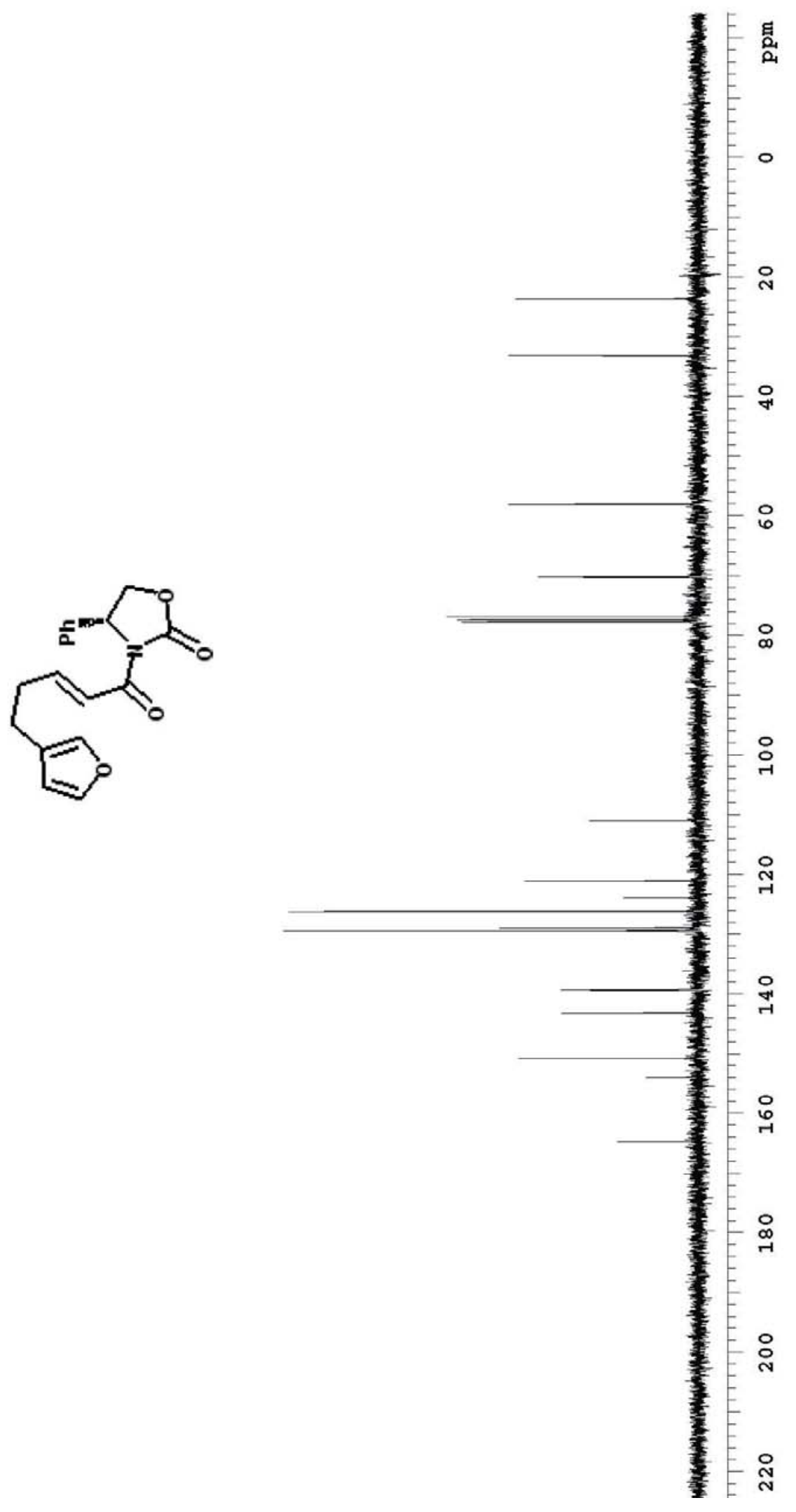

S-19 


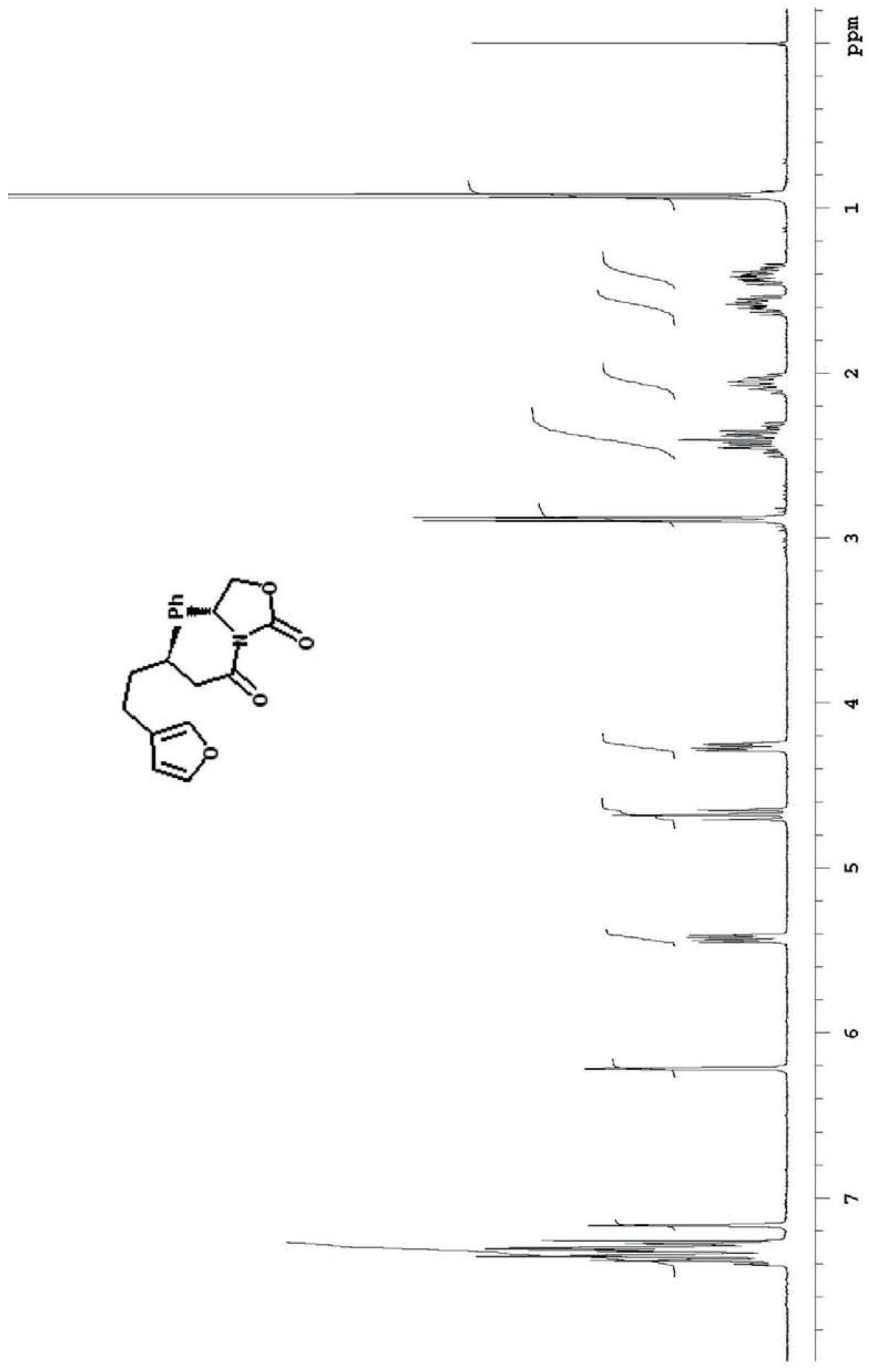

S-20 


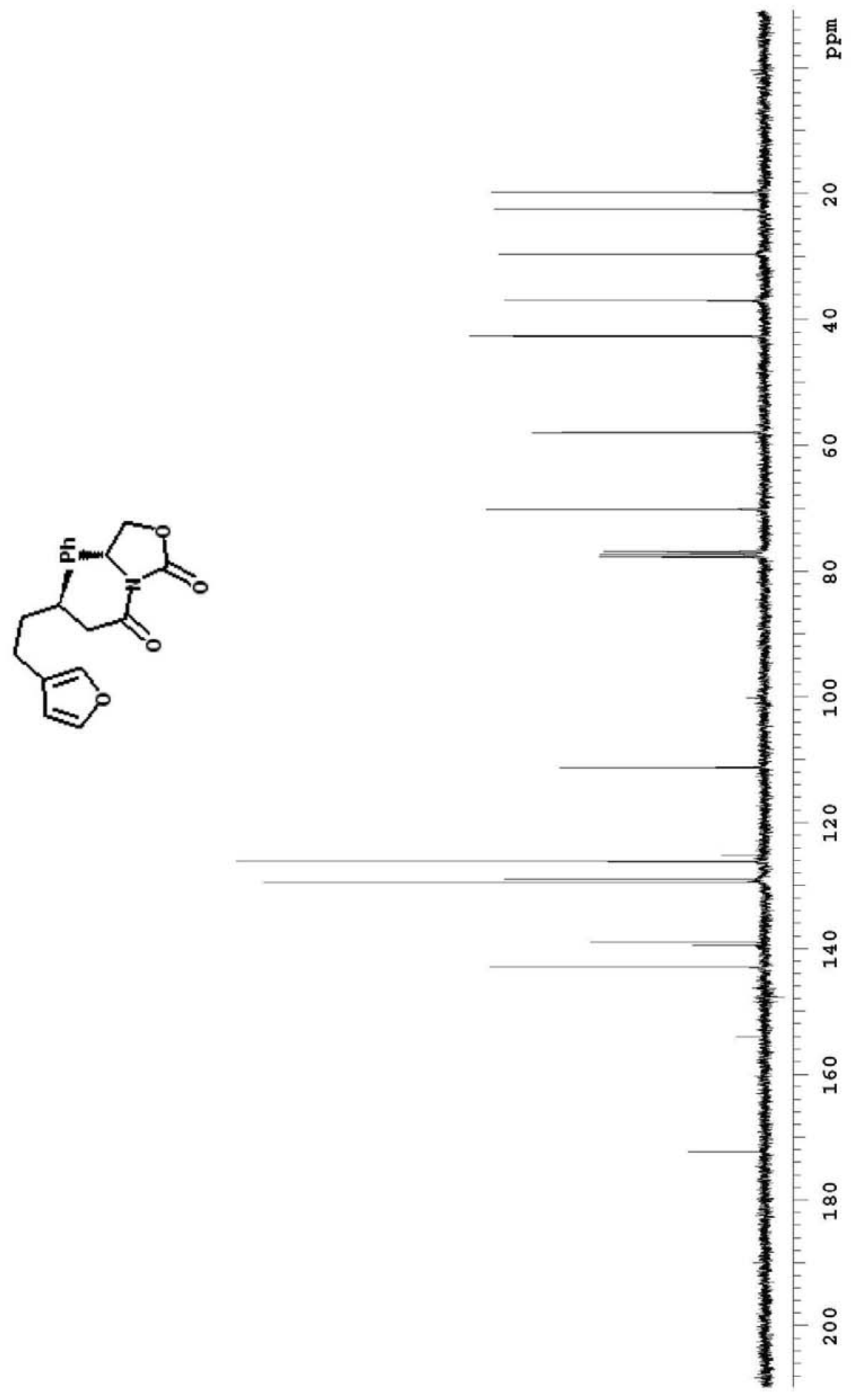

S-21 


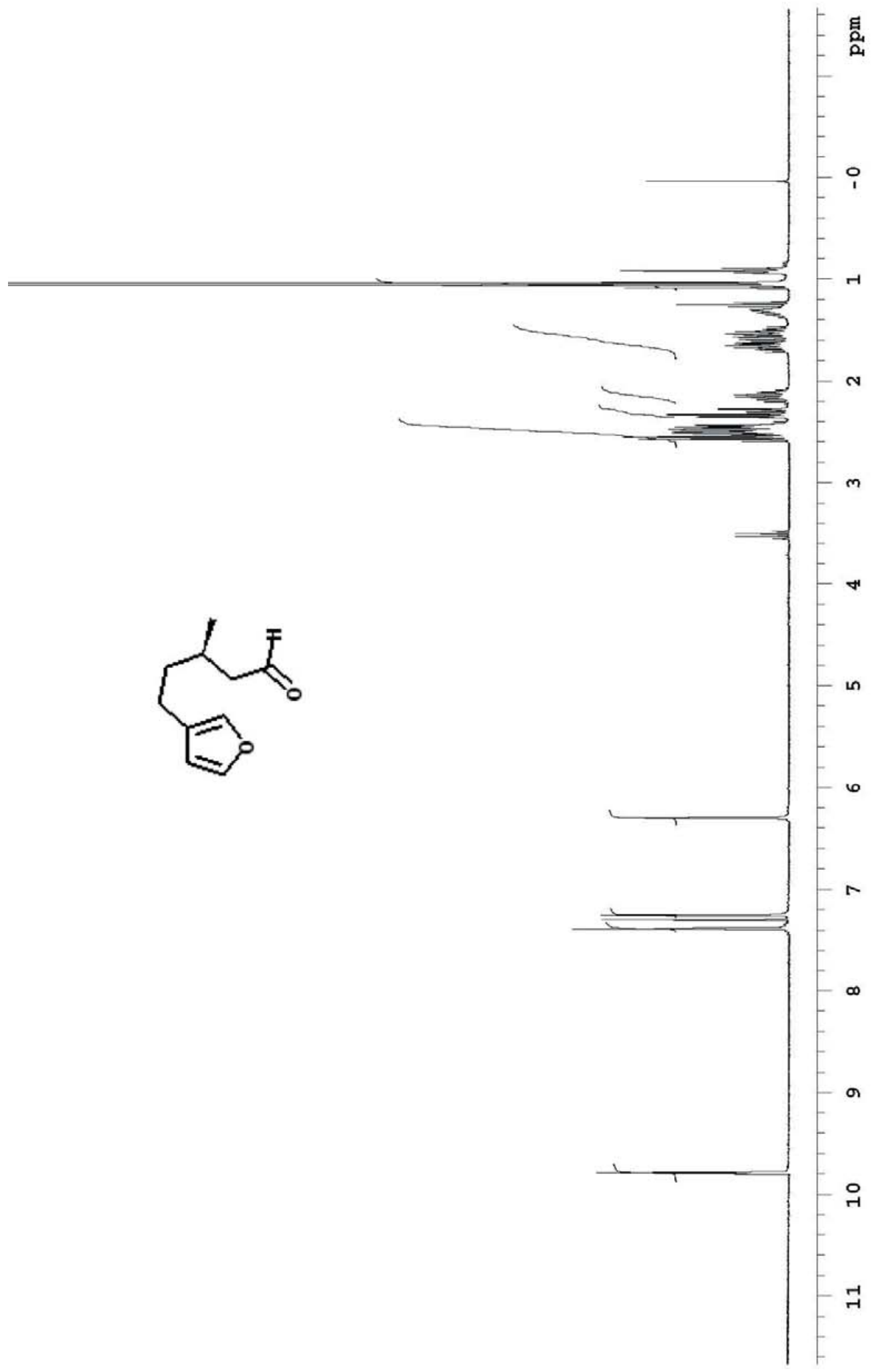

S-22 

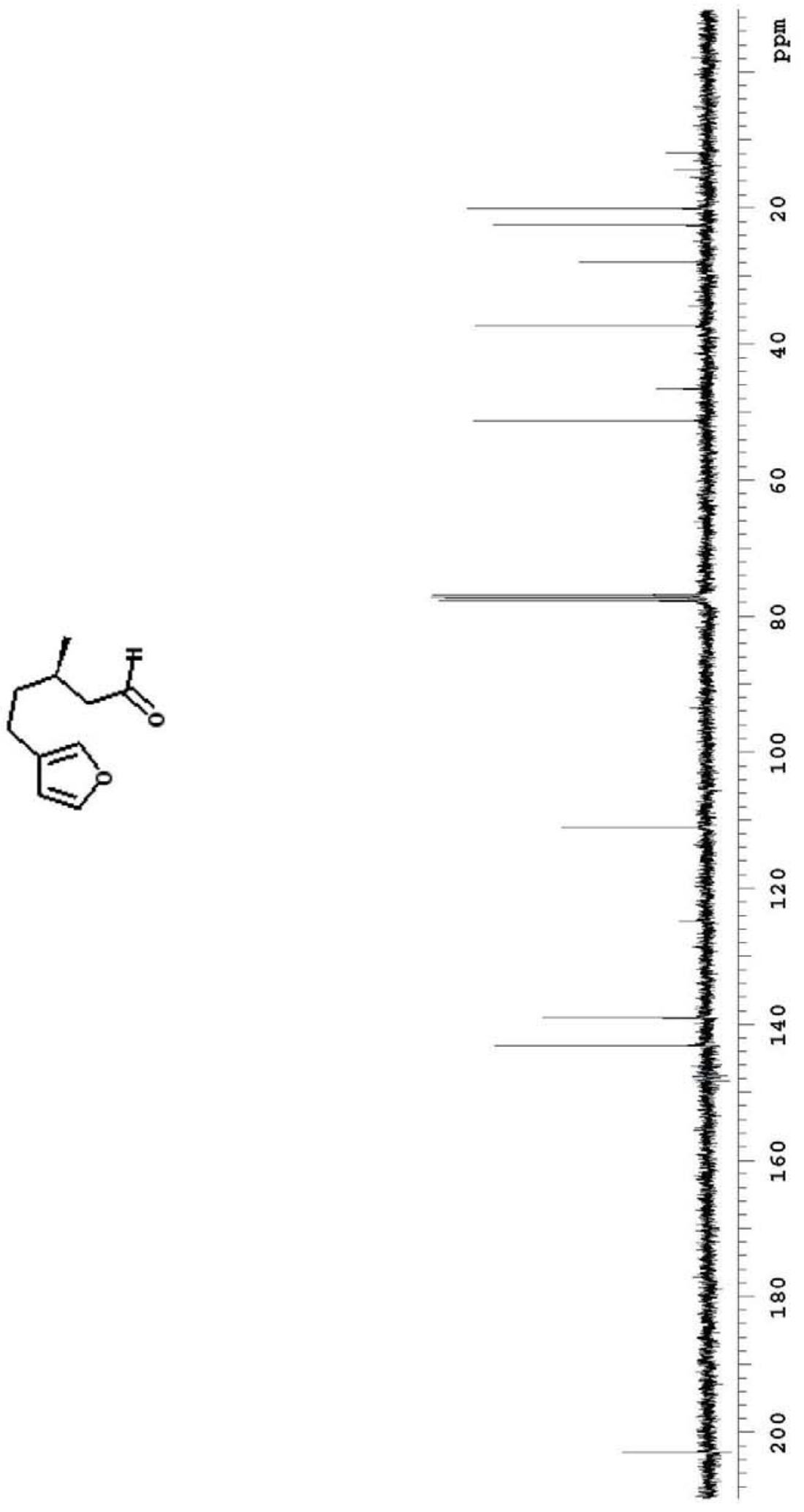

S-23 


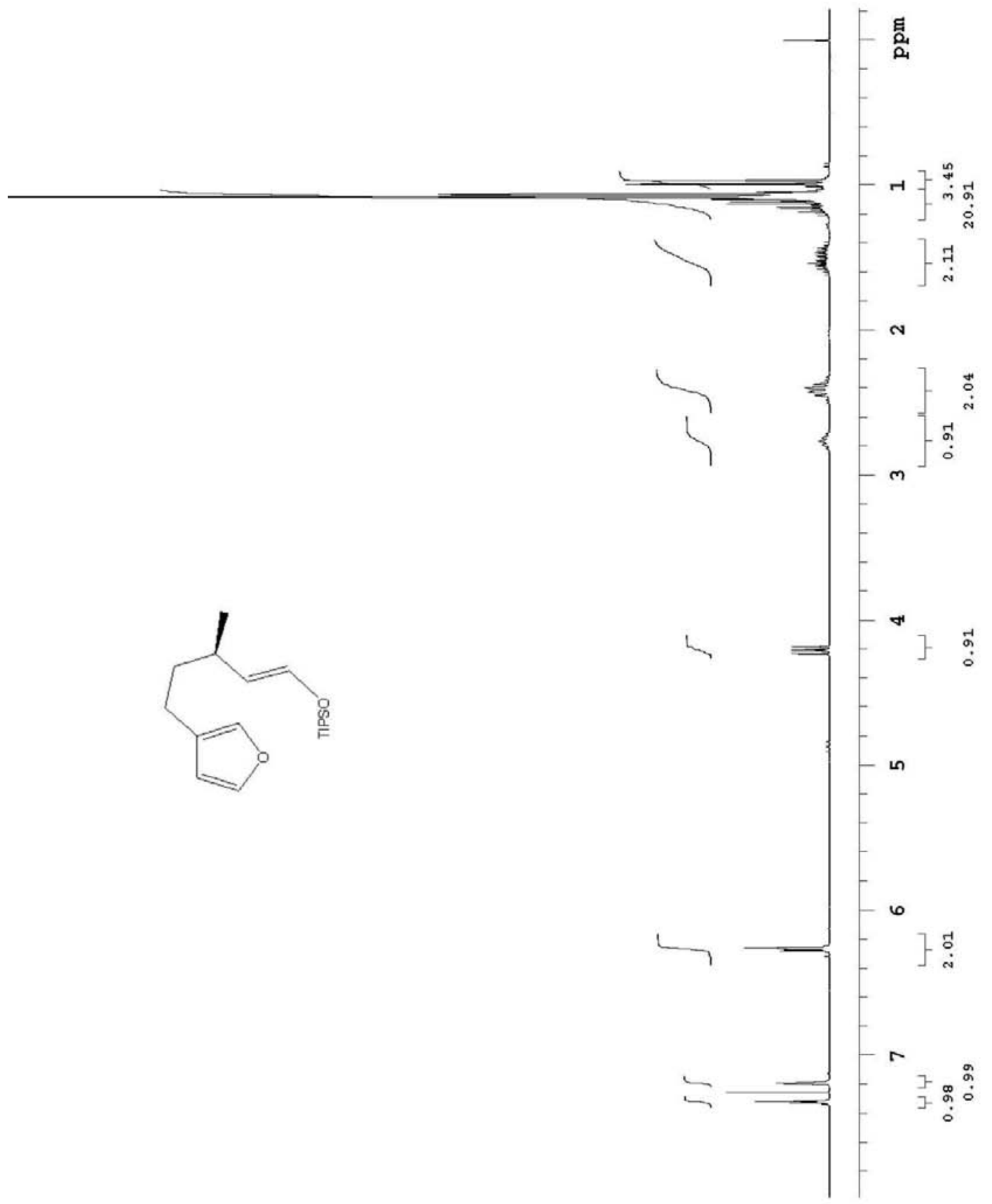




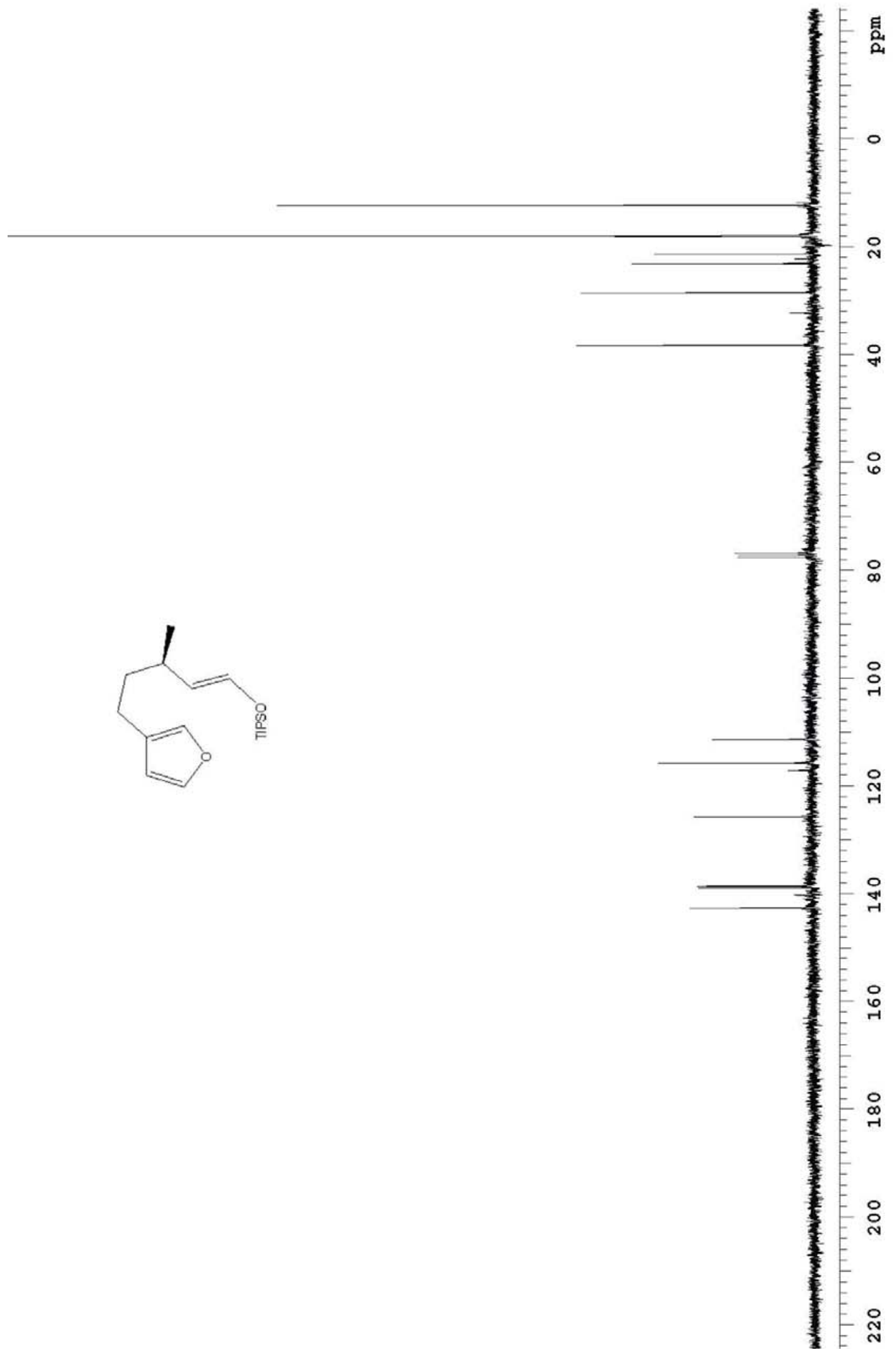

S-25 


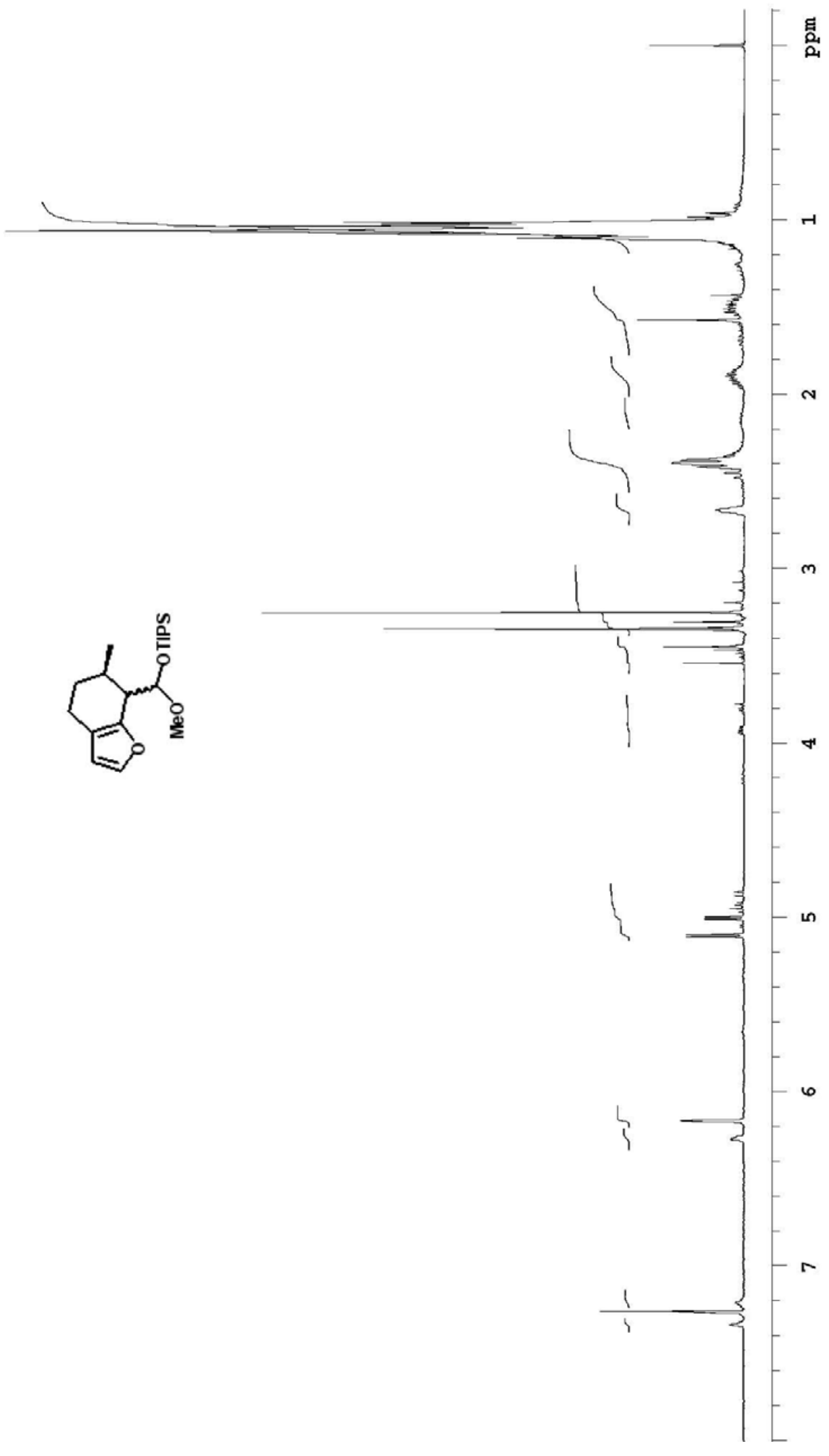

S-26 


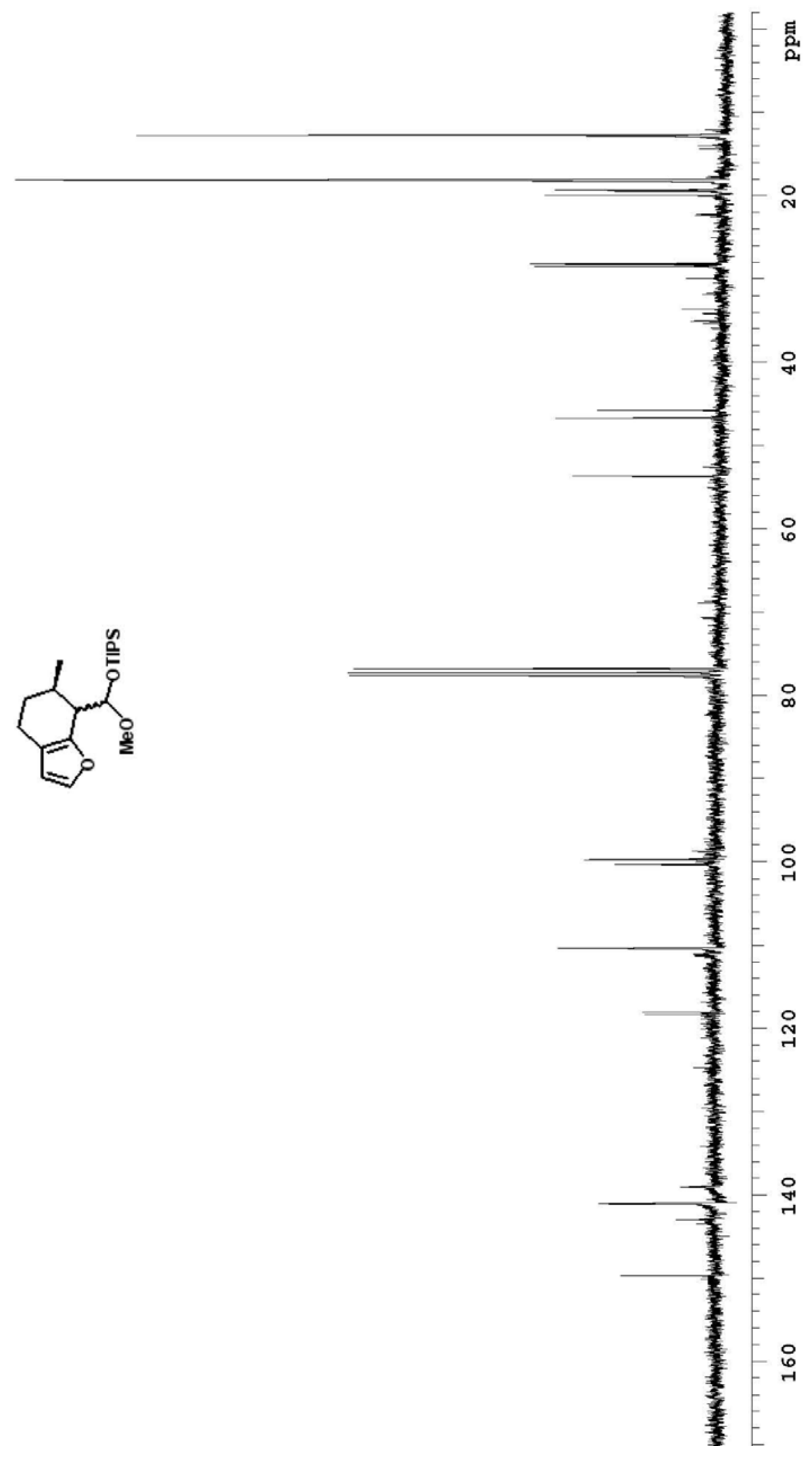

S-27 


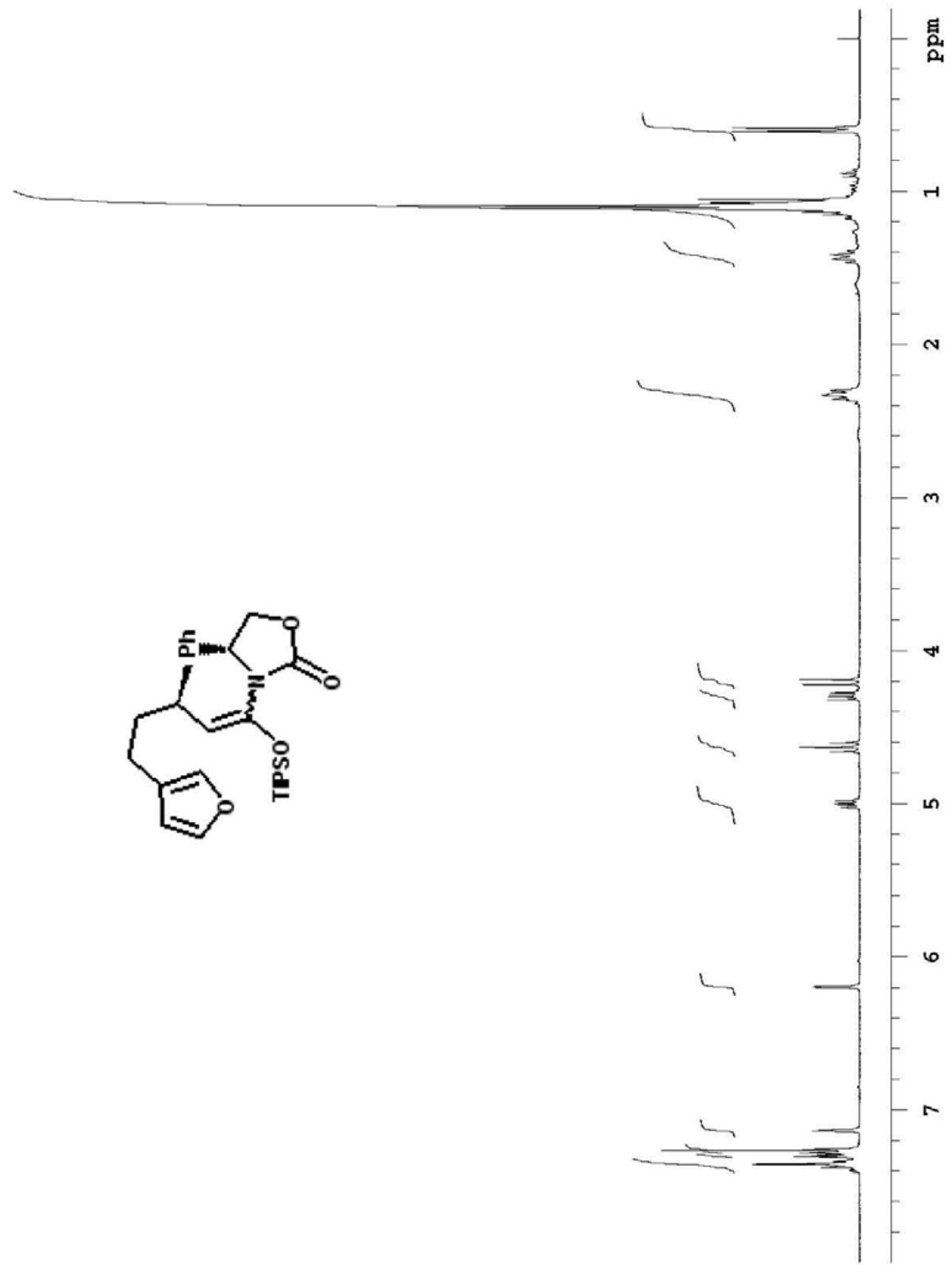



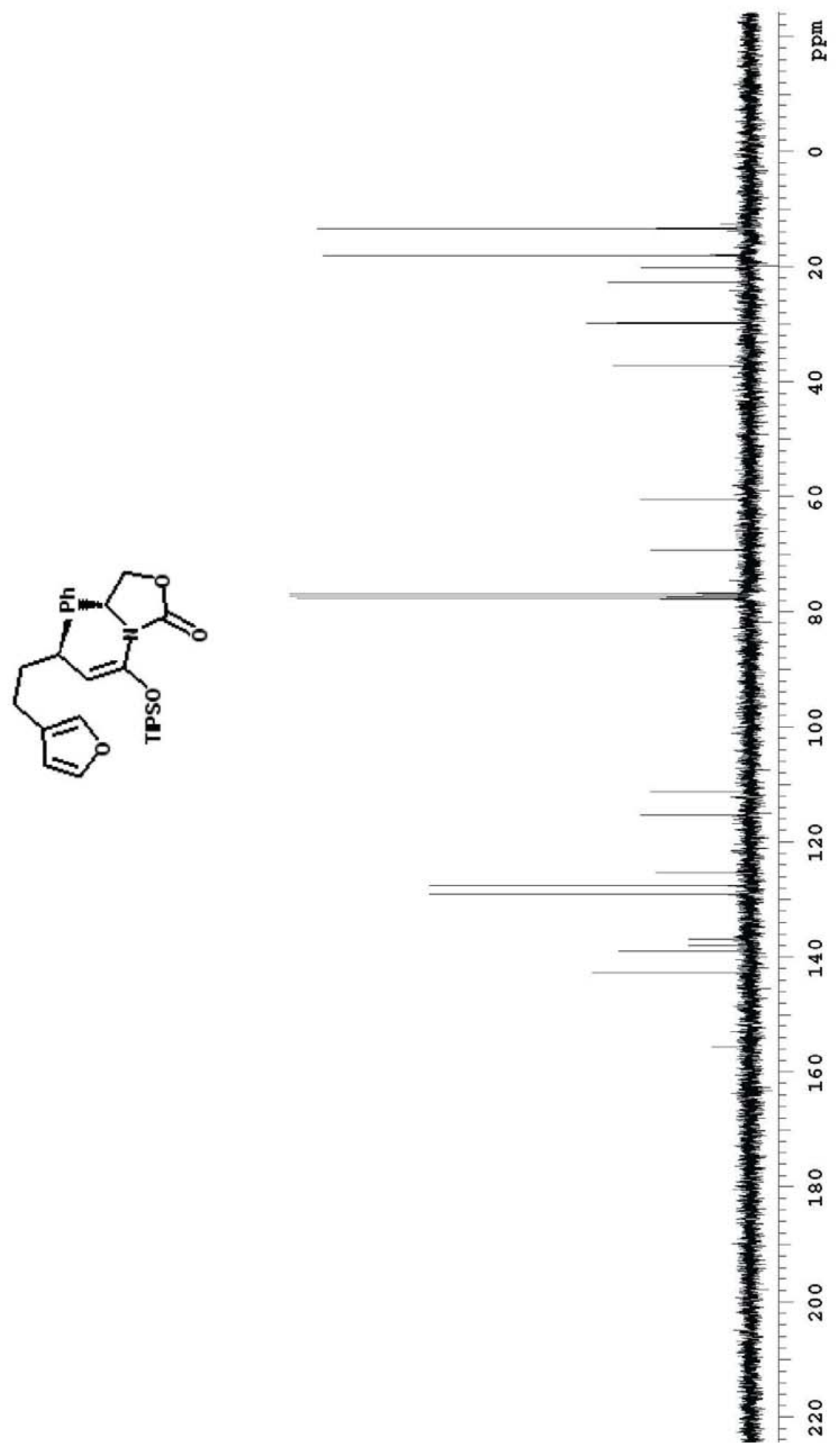

S-29 


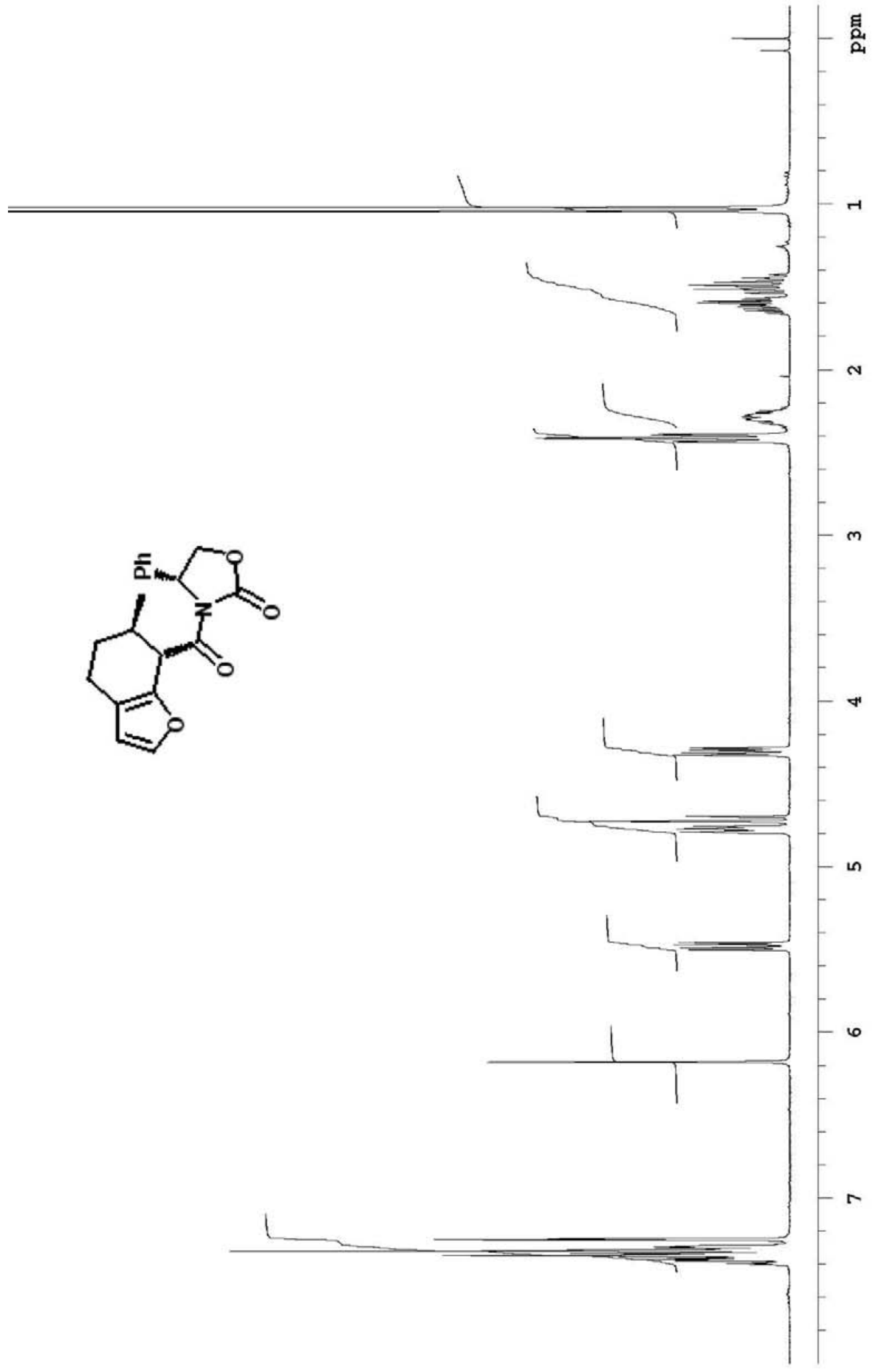

S-30 


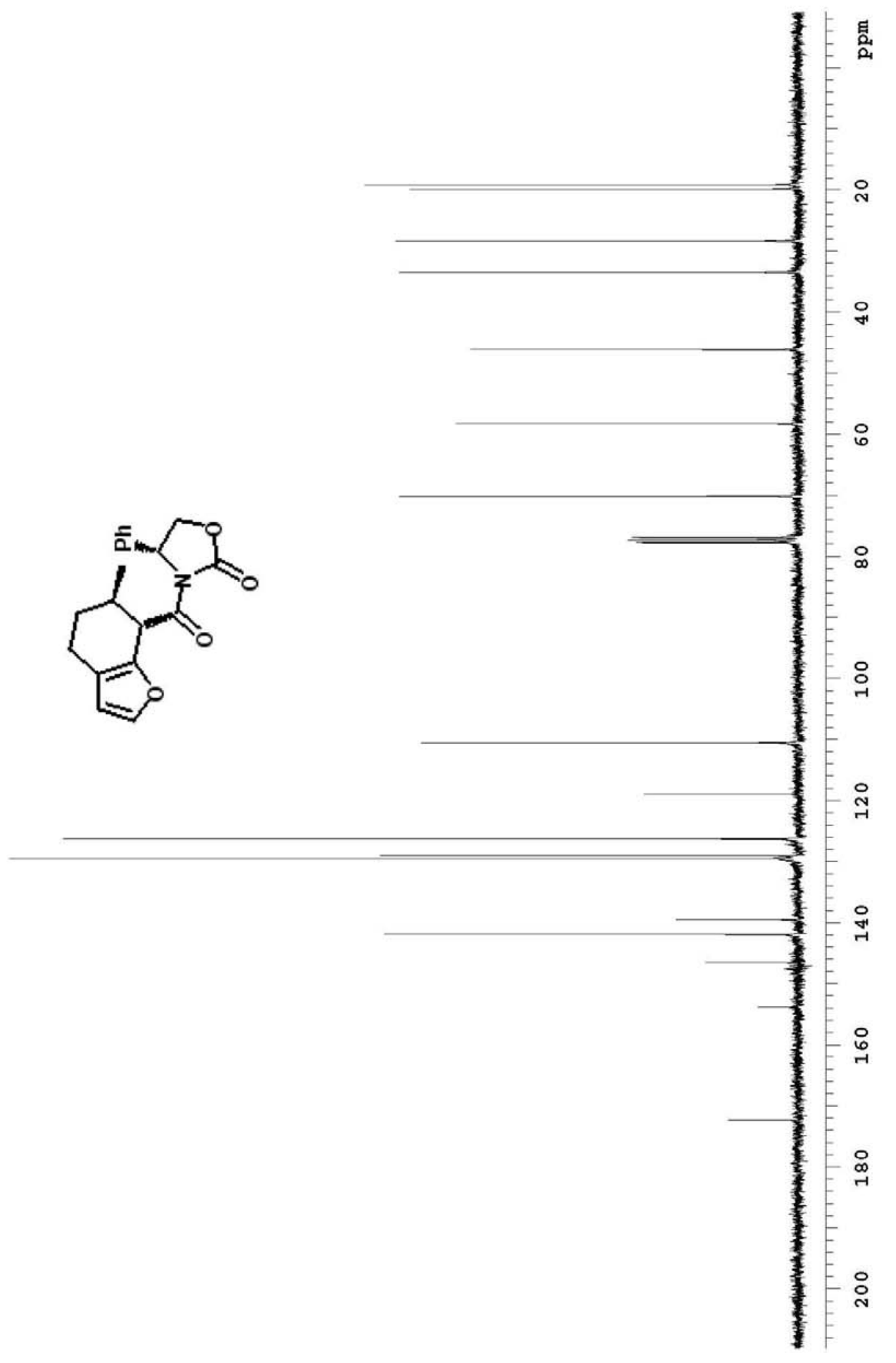

S-31 


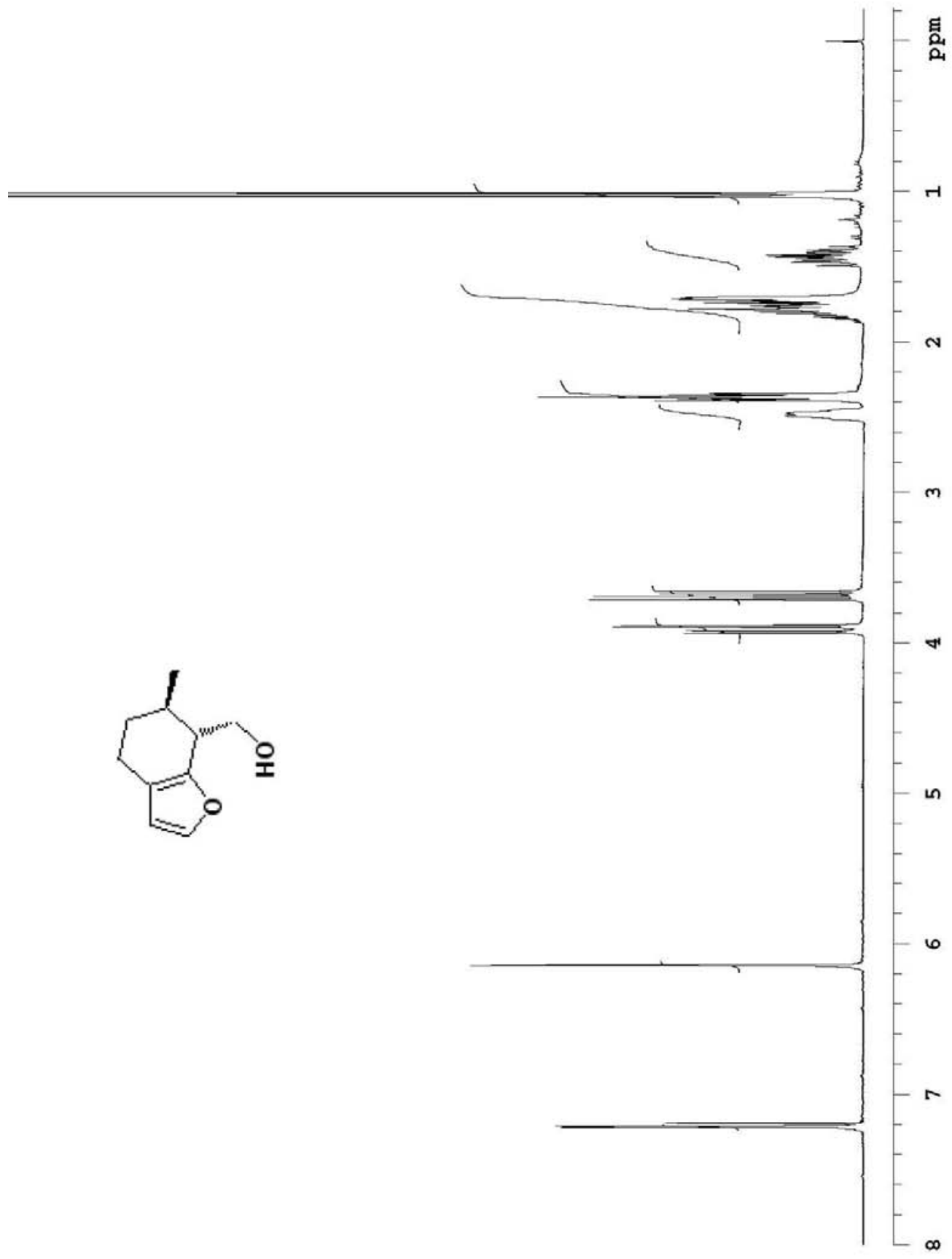

S-32 

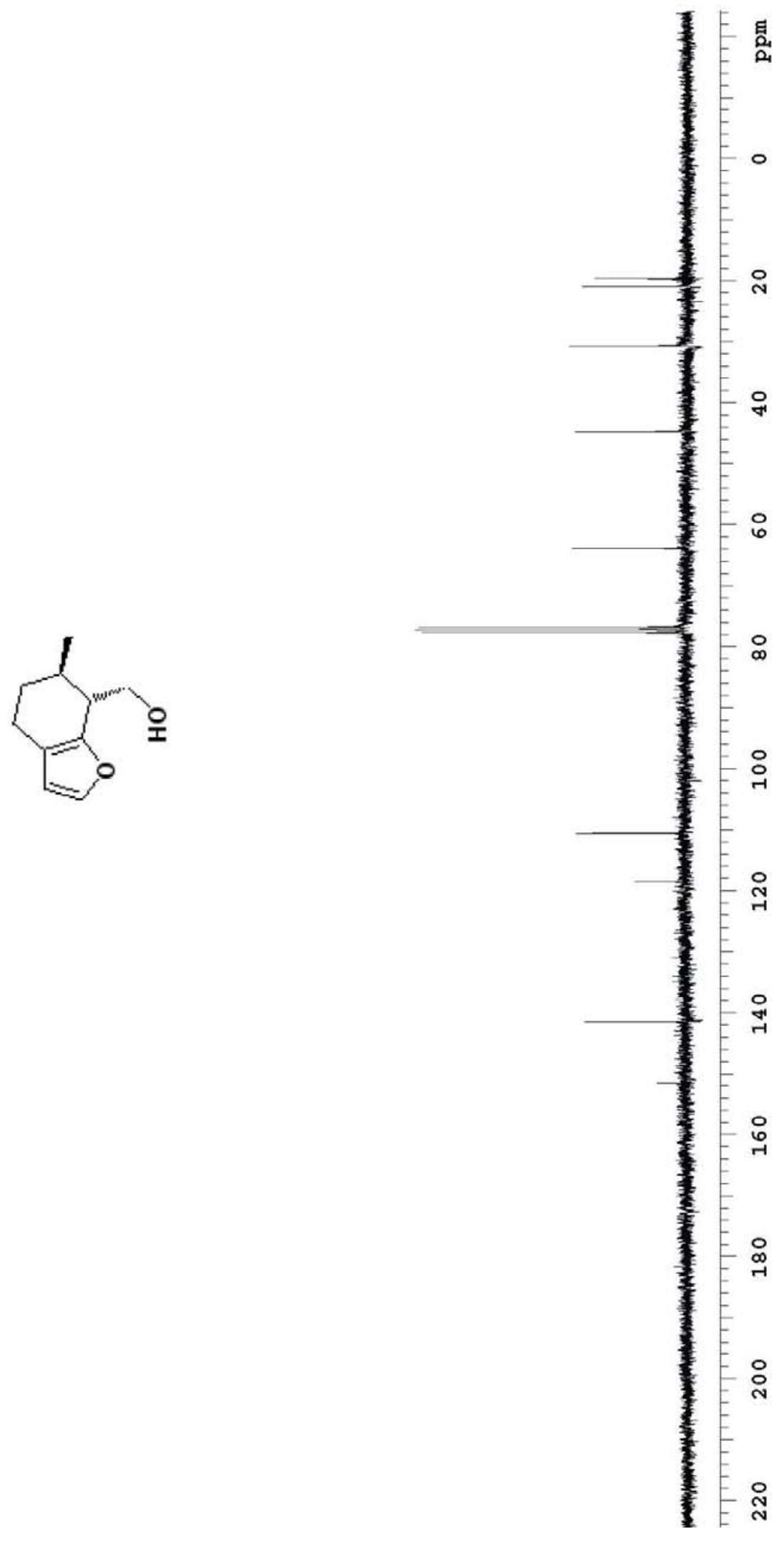

S-33 


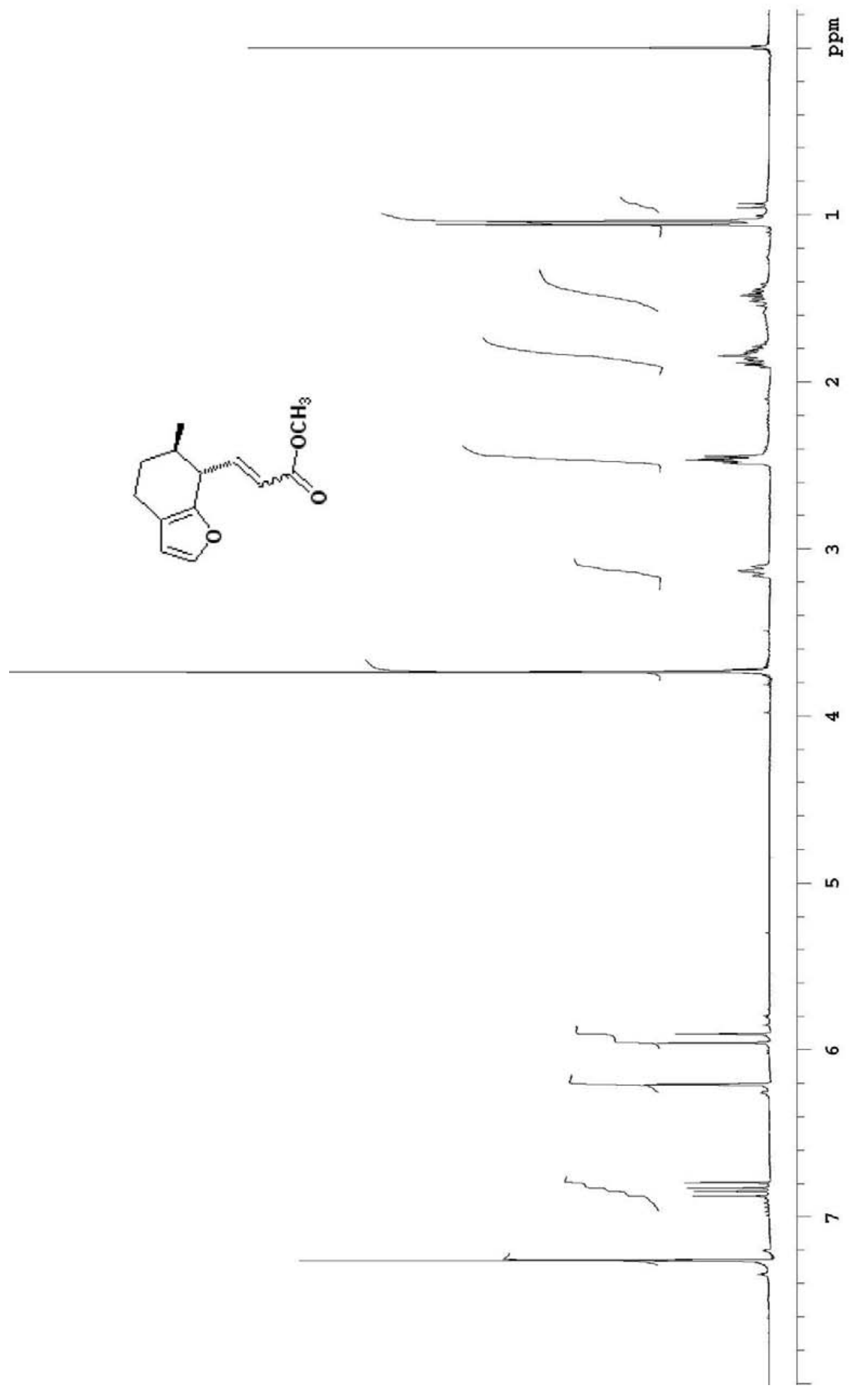

S-34 

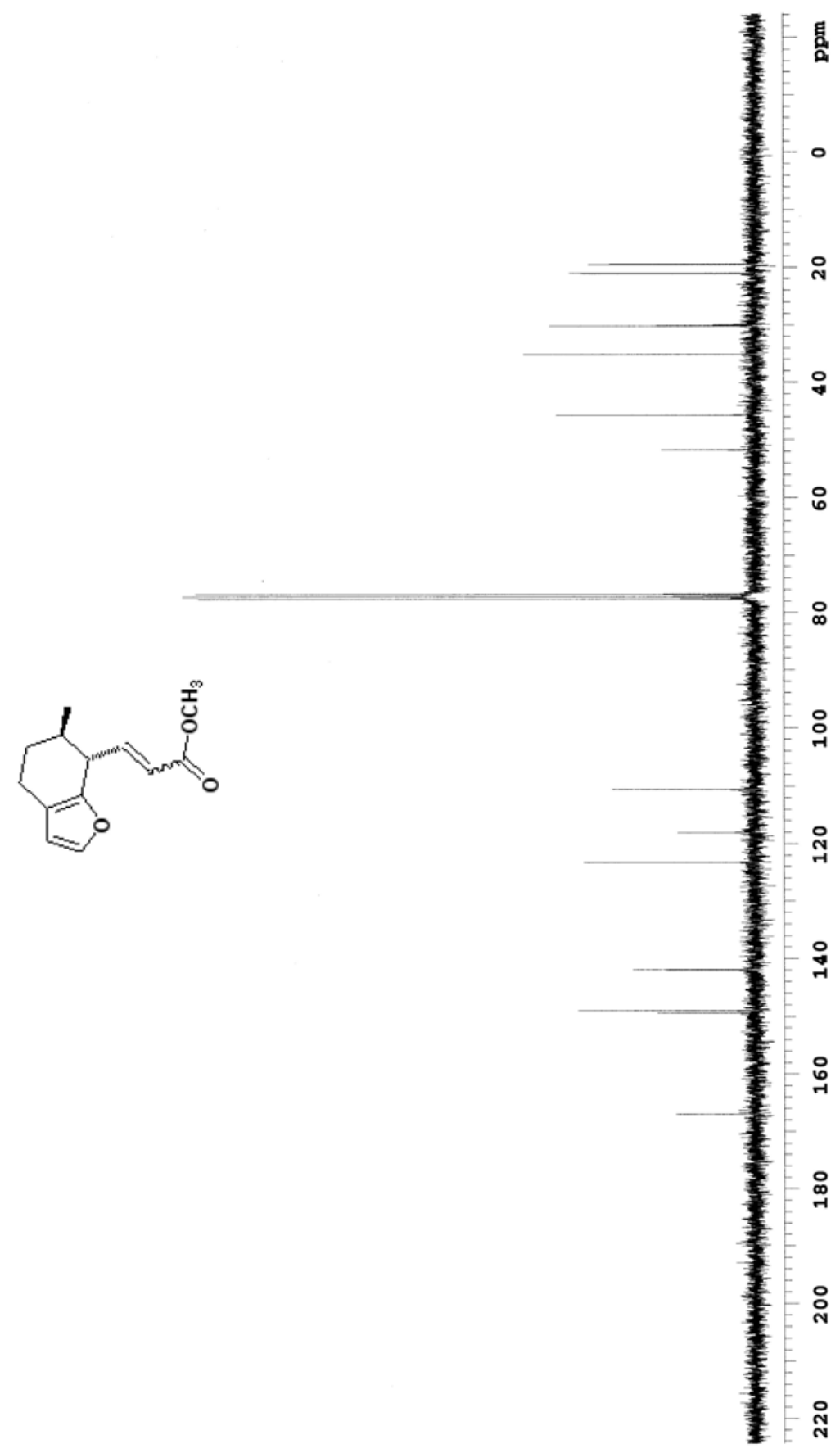

S-35 


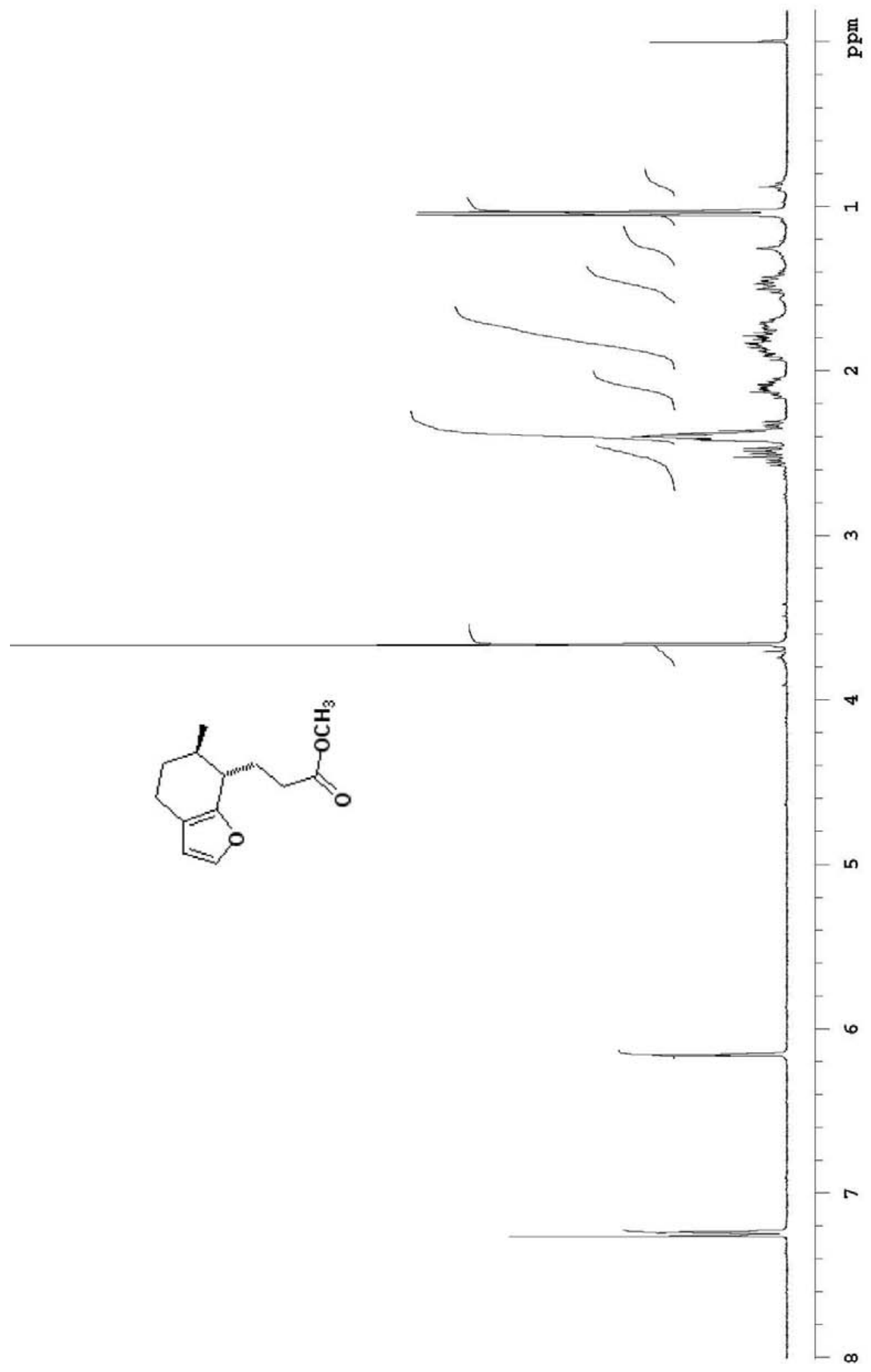

S-36 

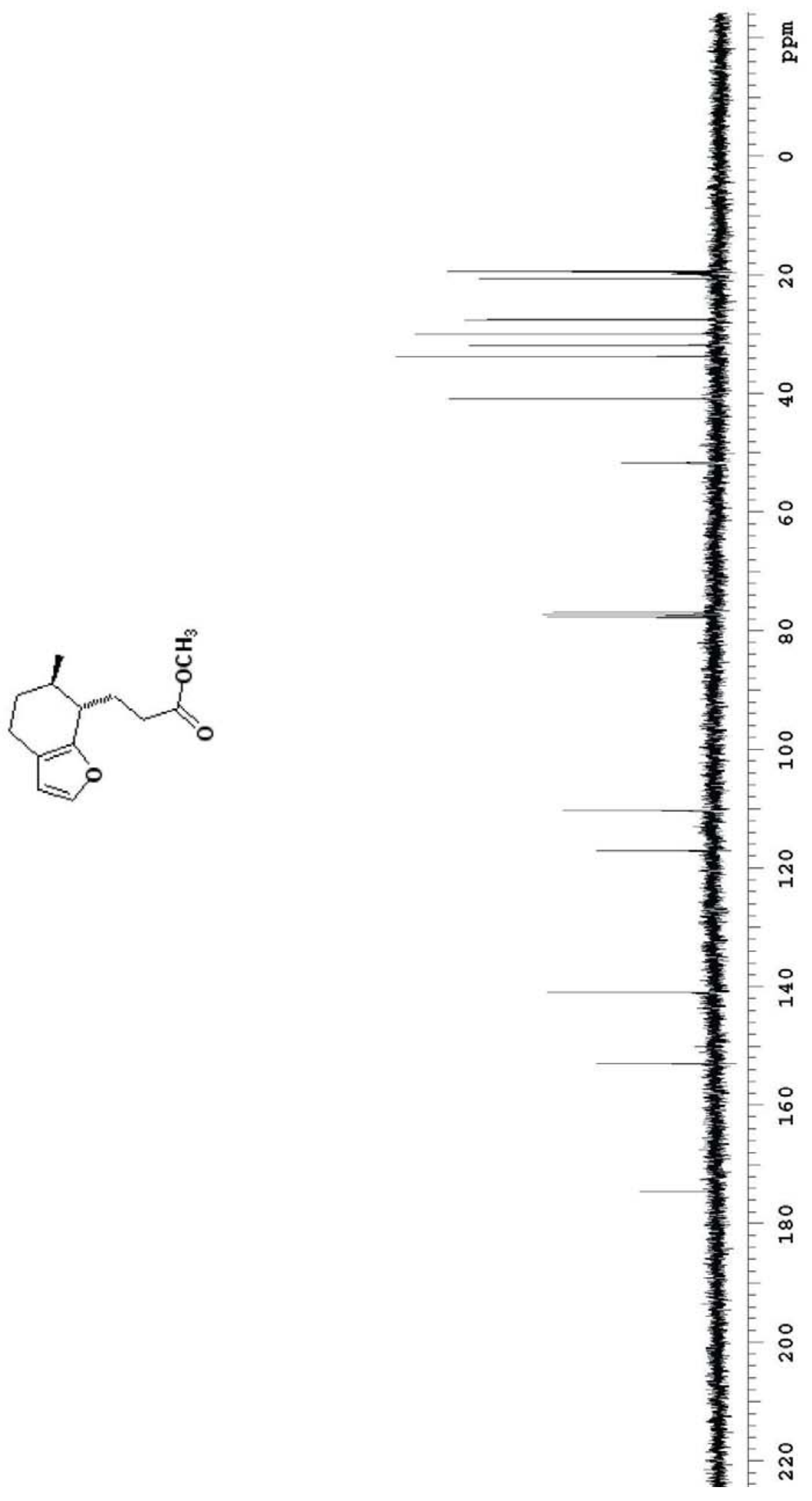

S-37 


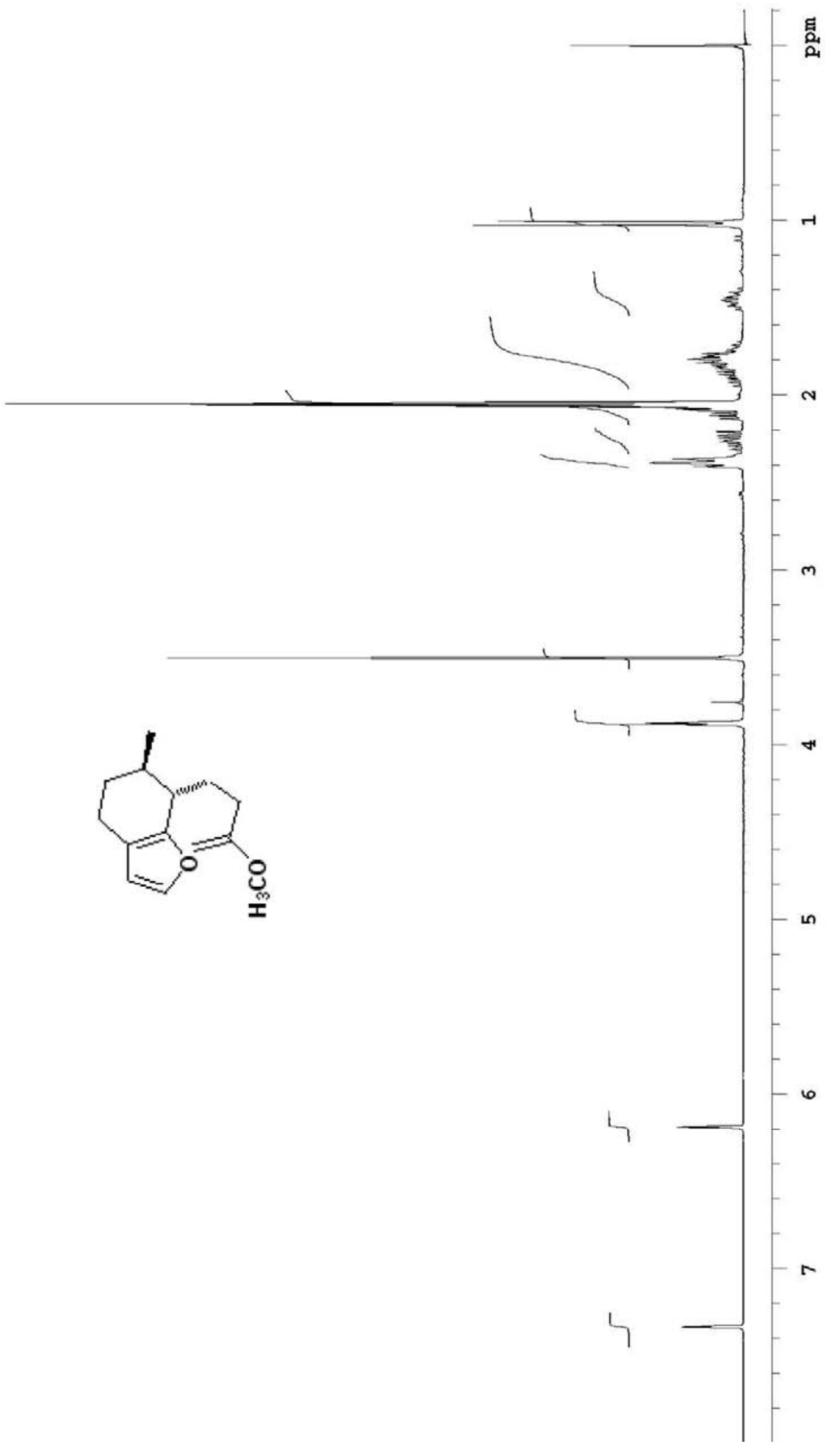

S-38 


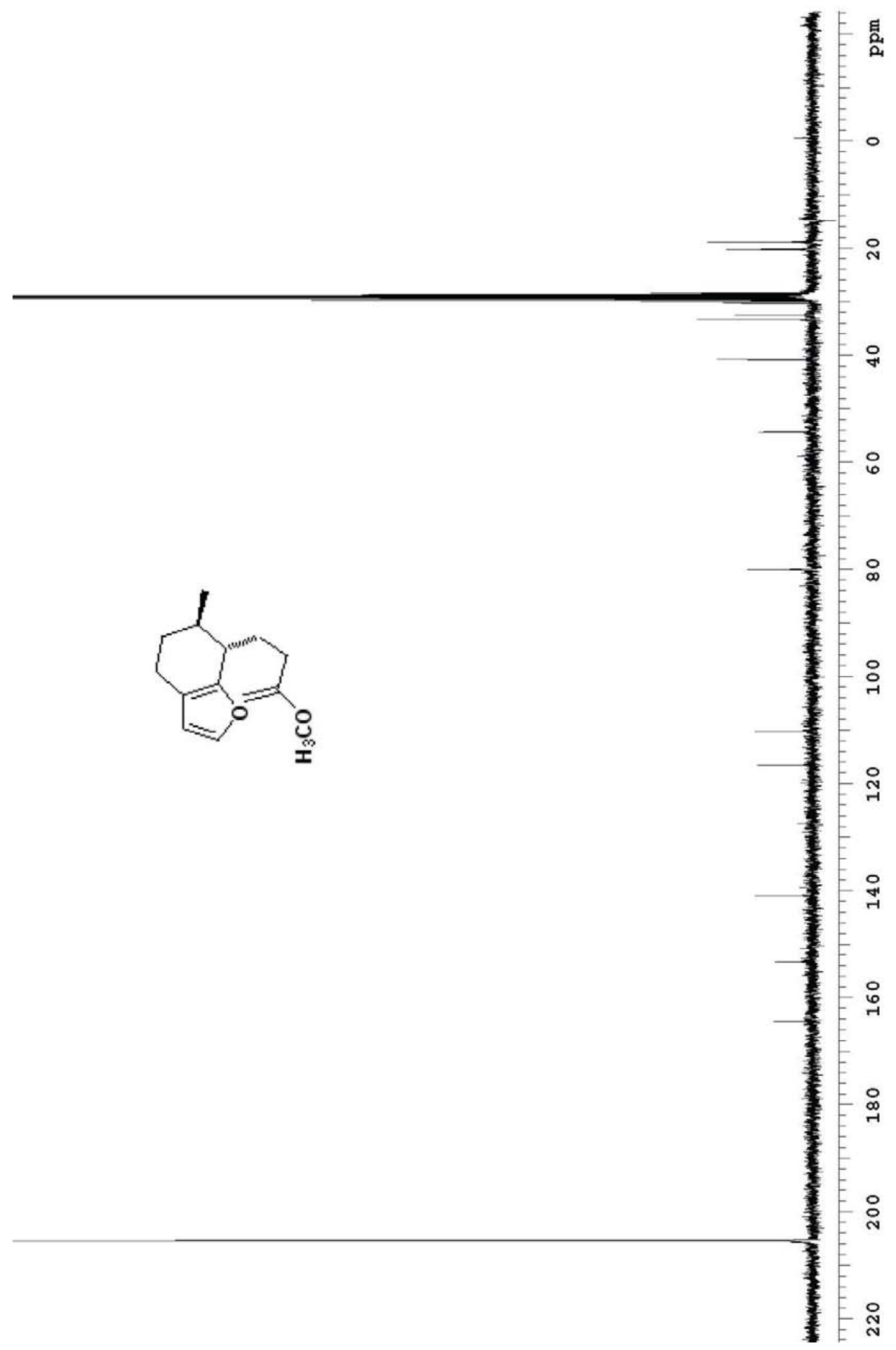

S-39 


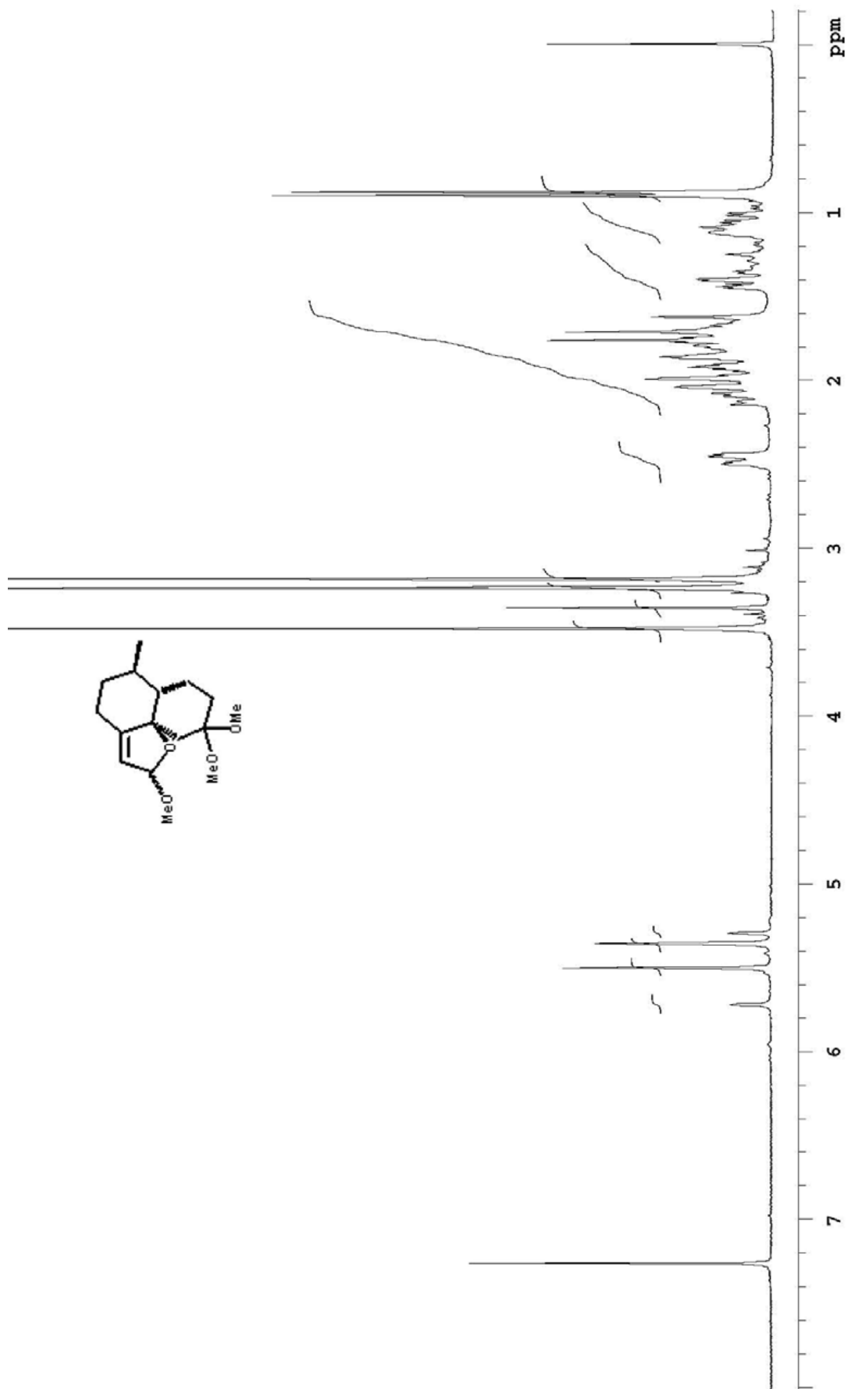



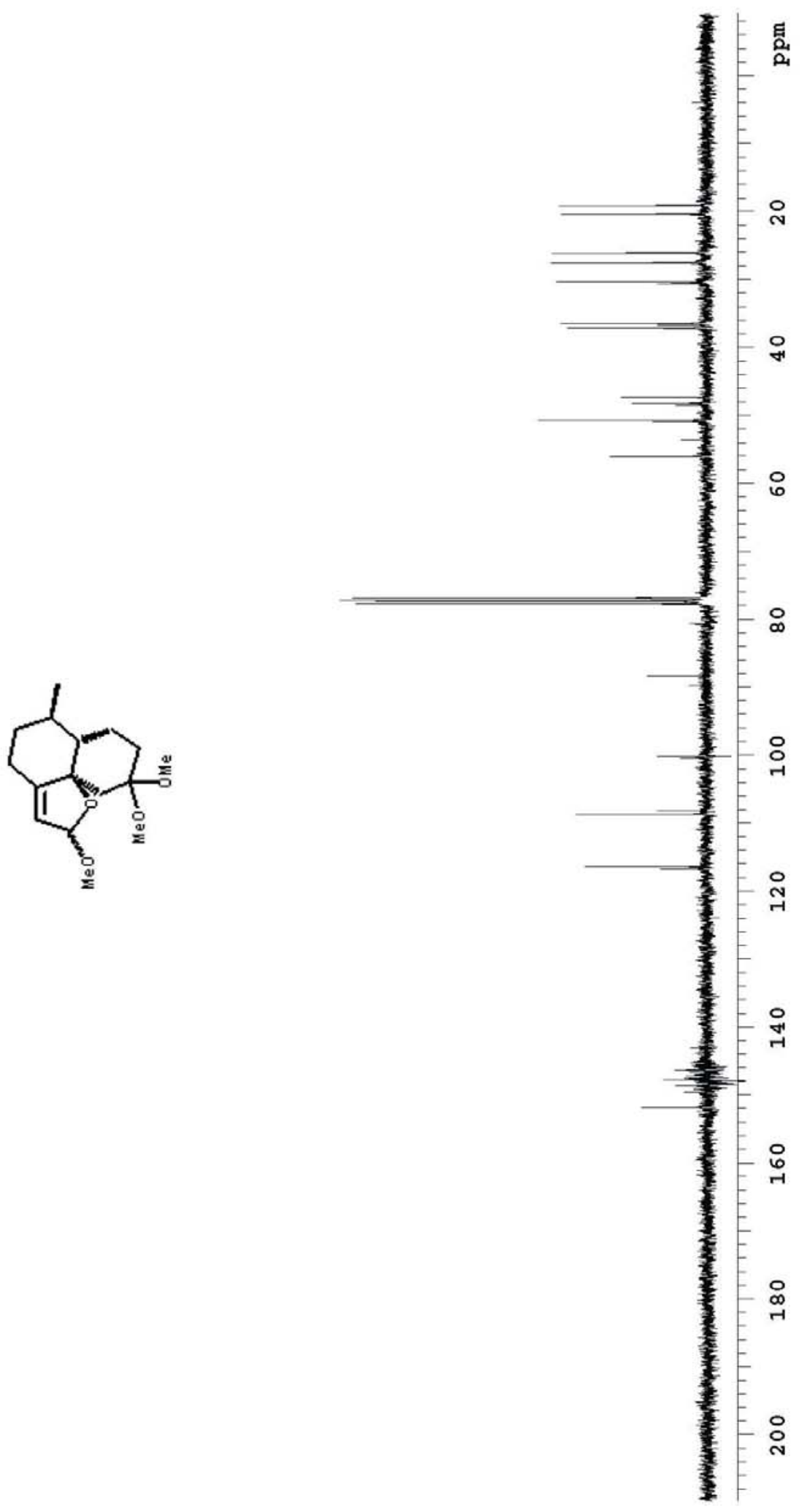

S-41 


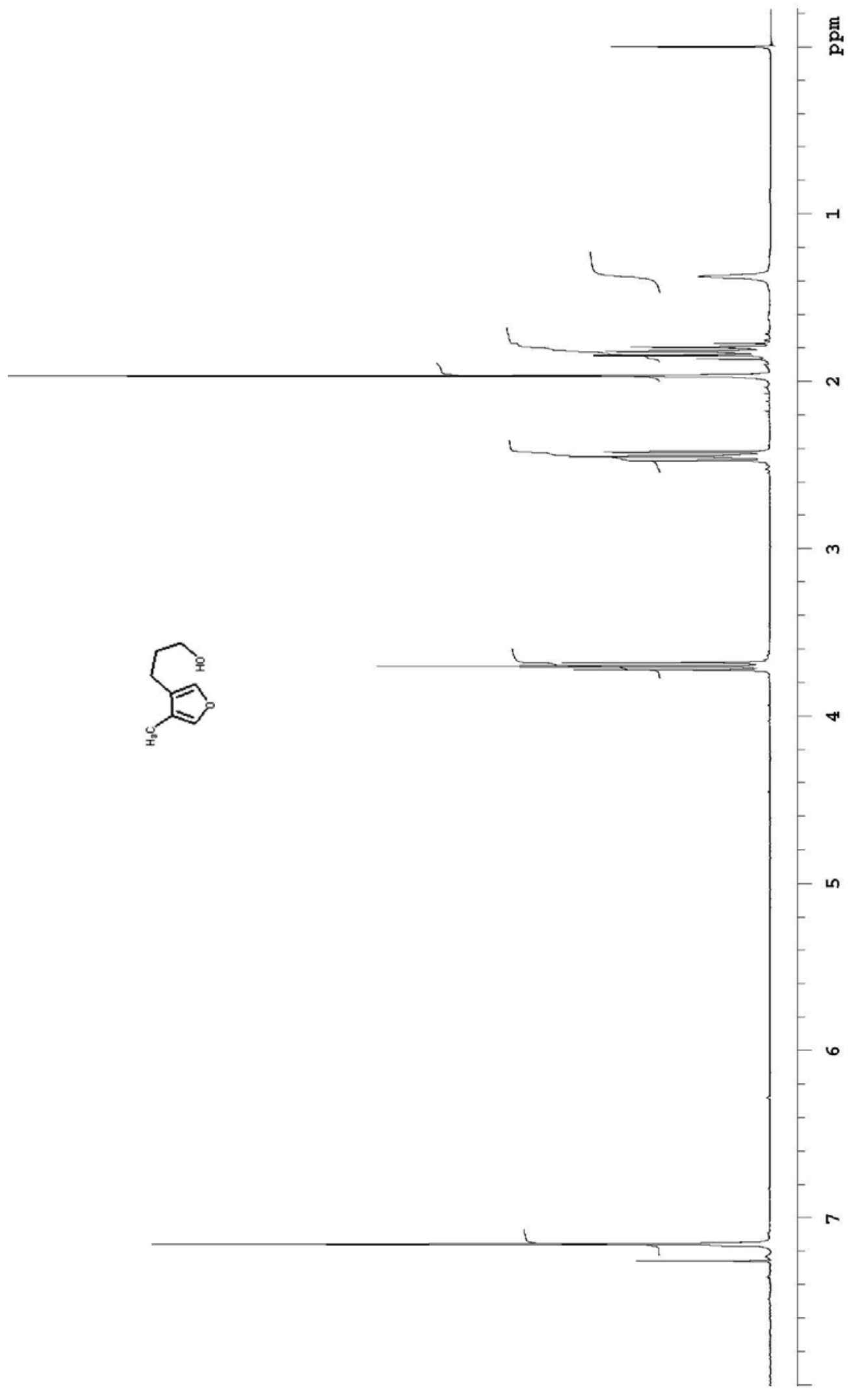




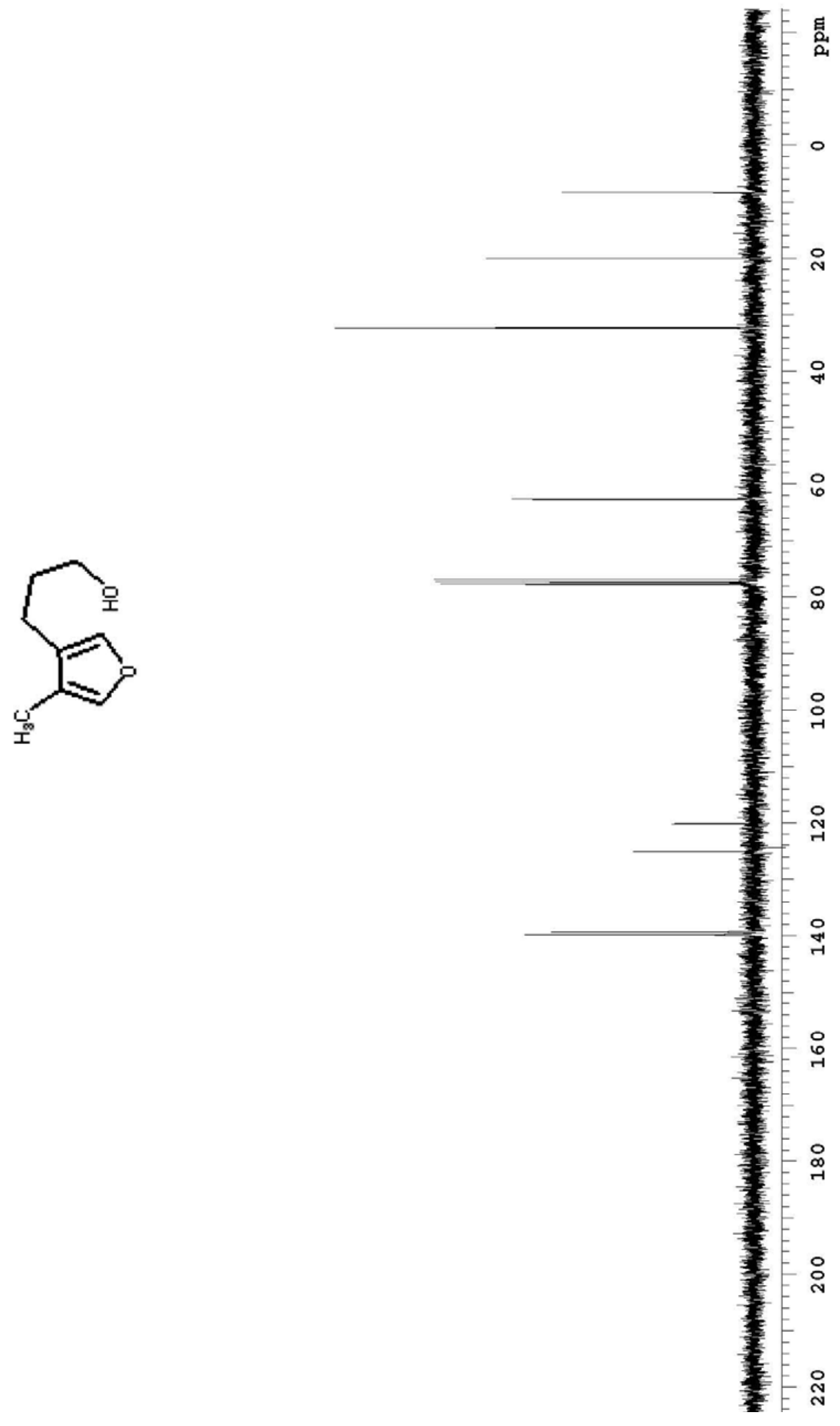

S-43 


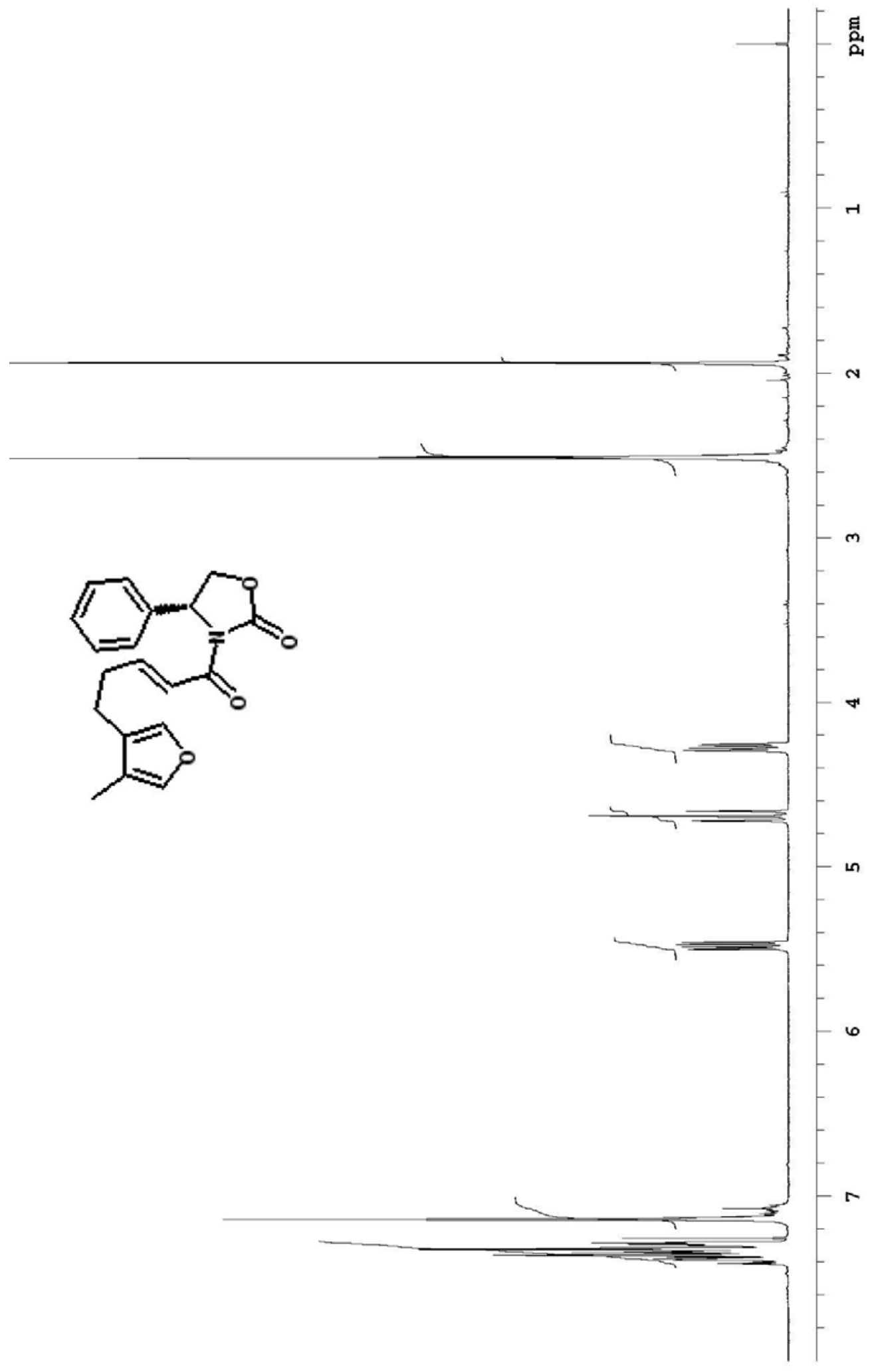




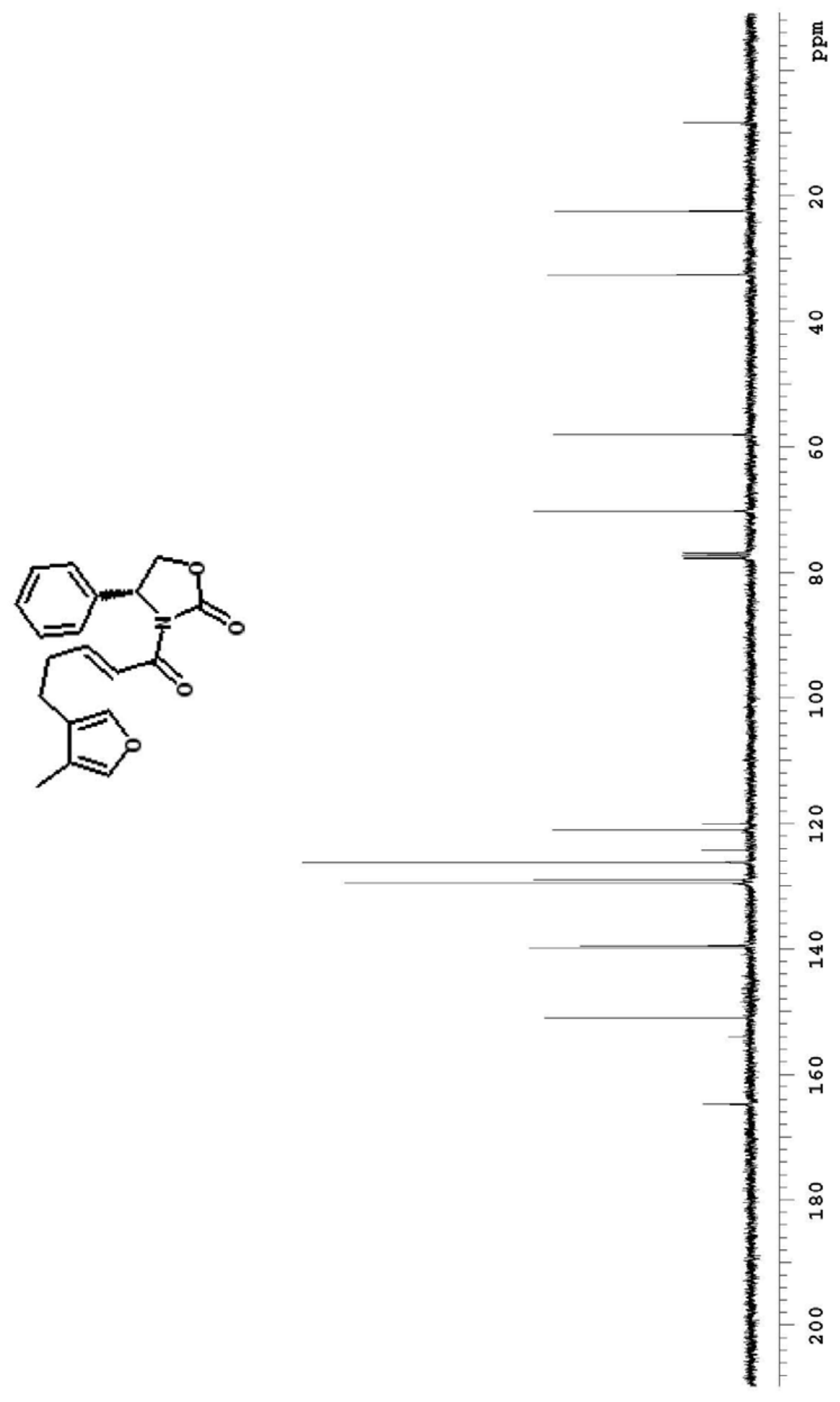




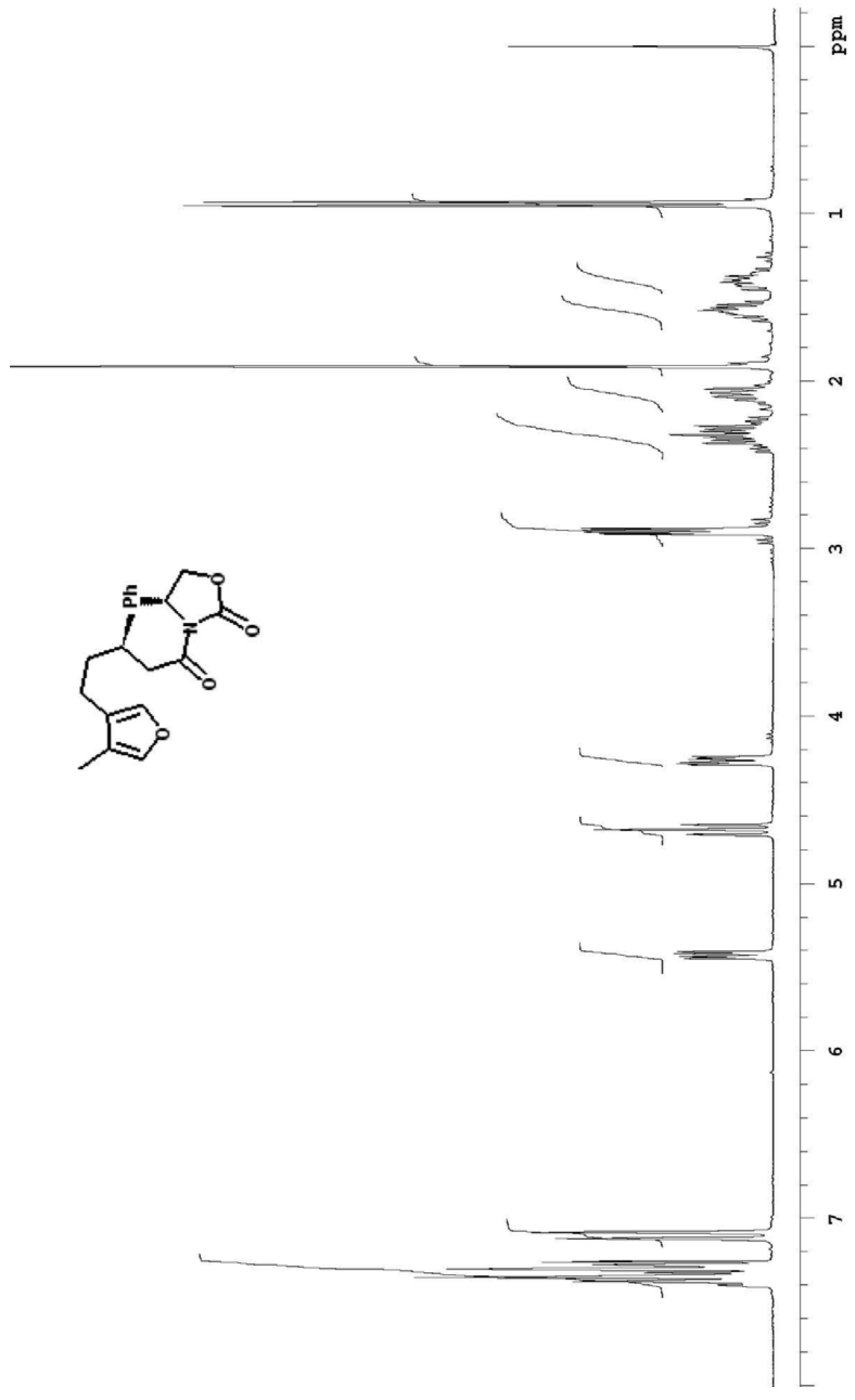




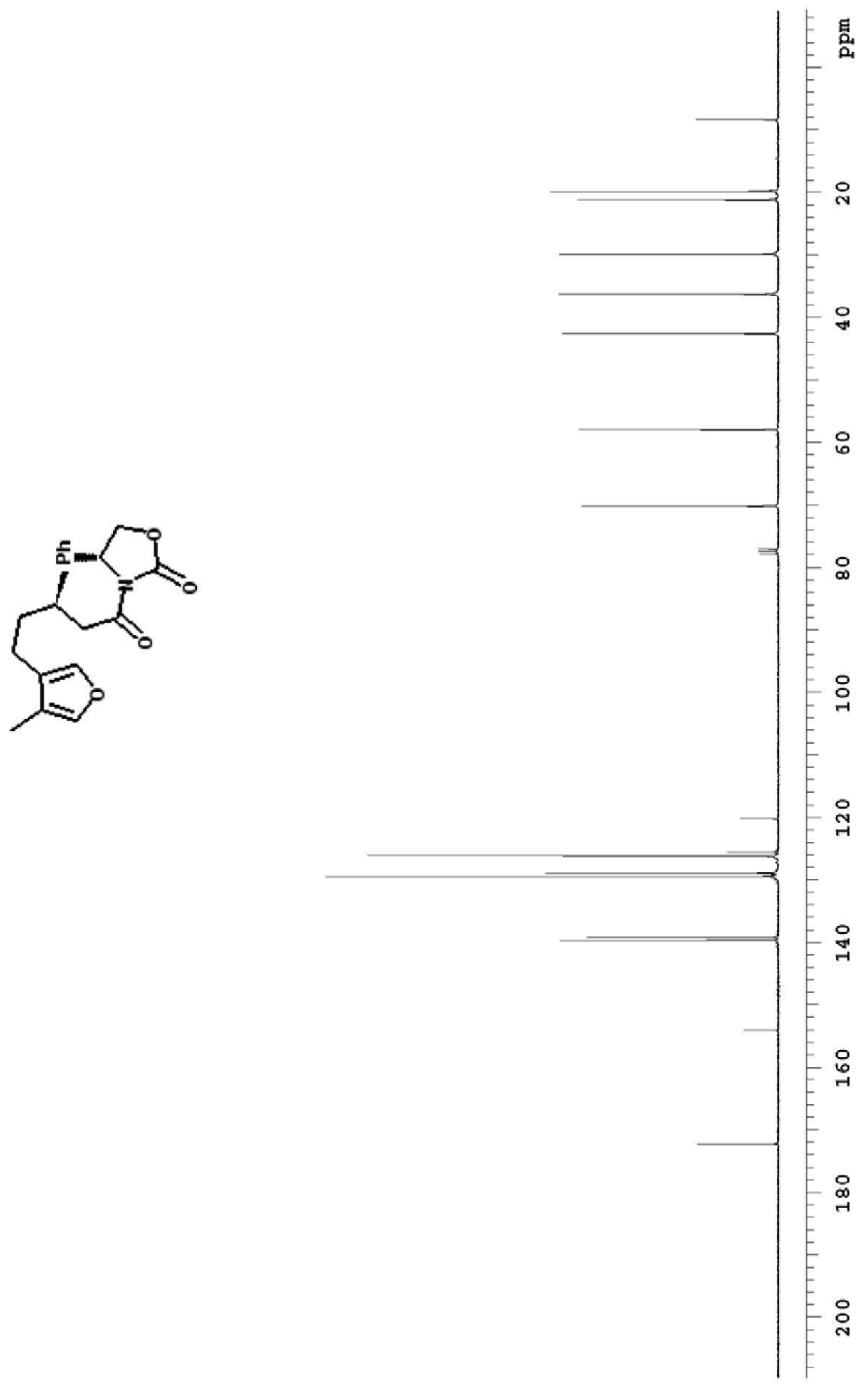




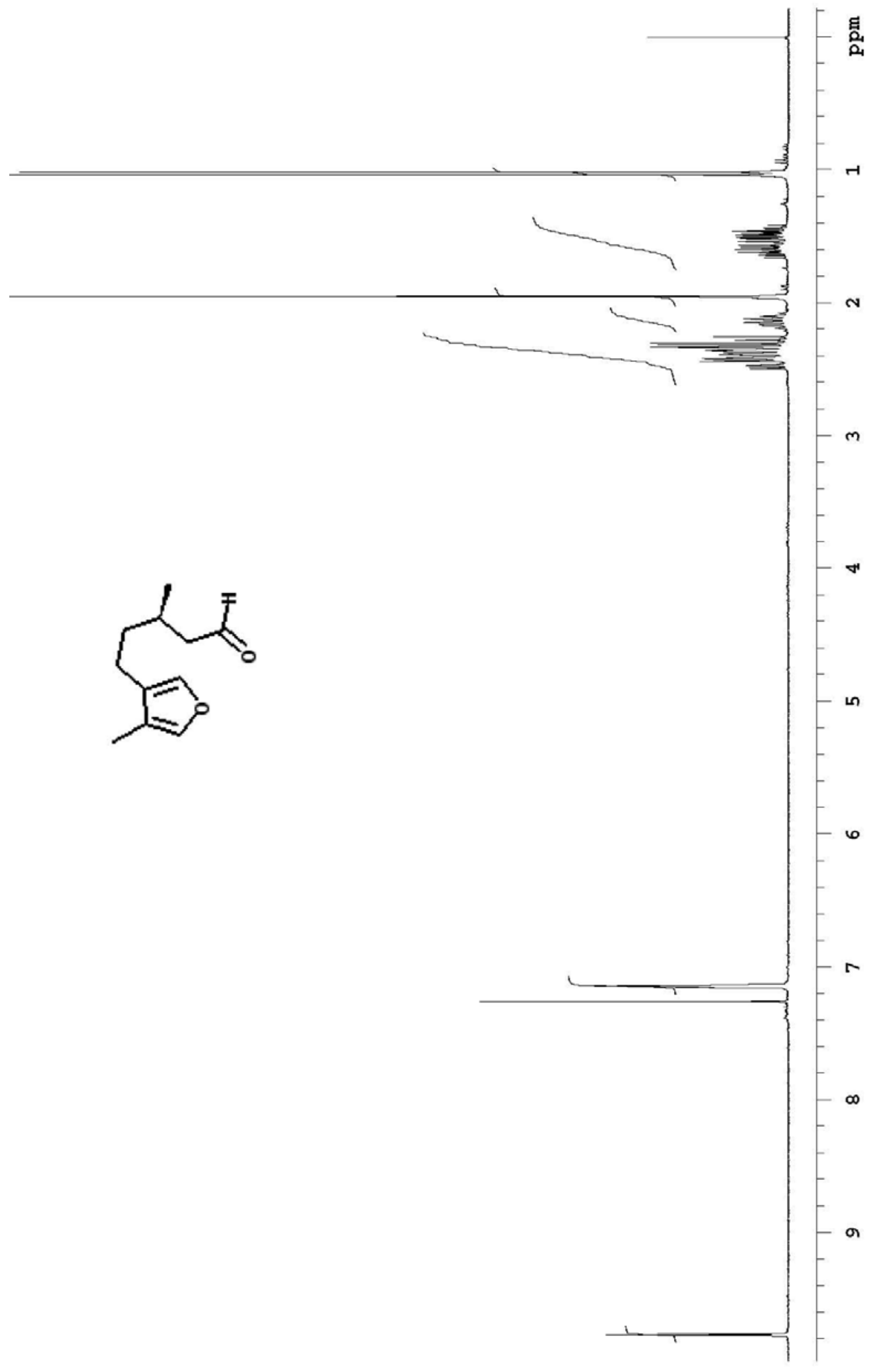



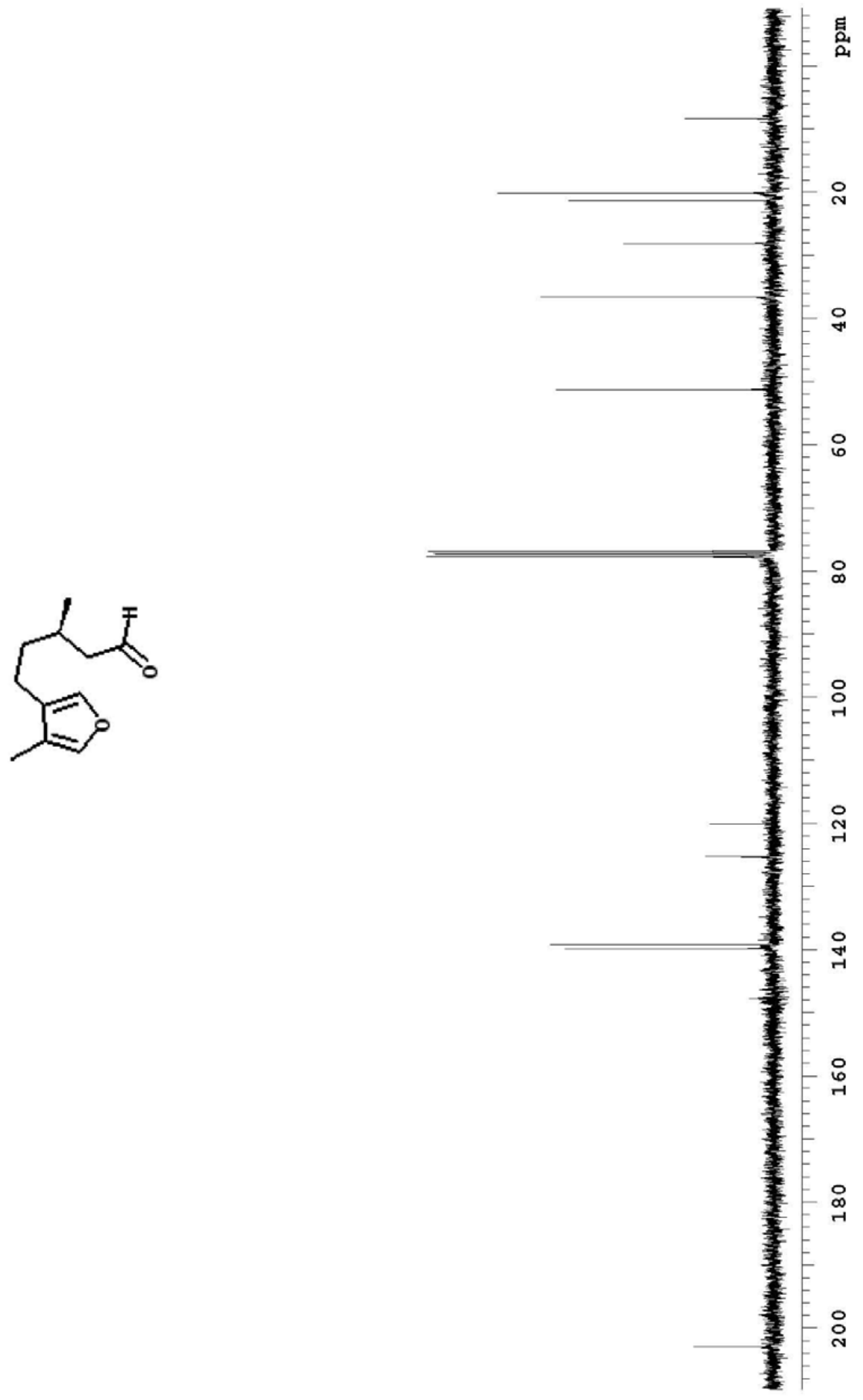

S-49 


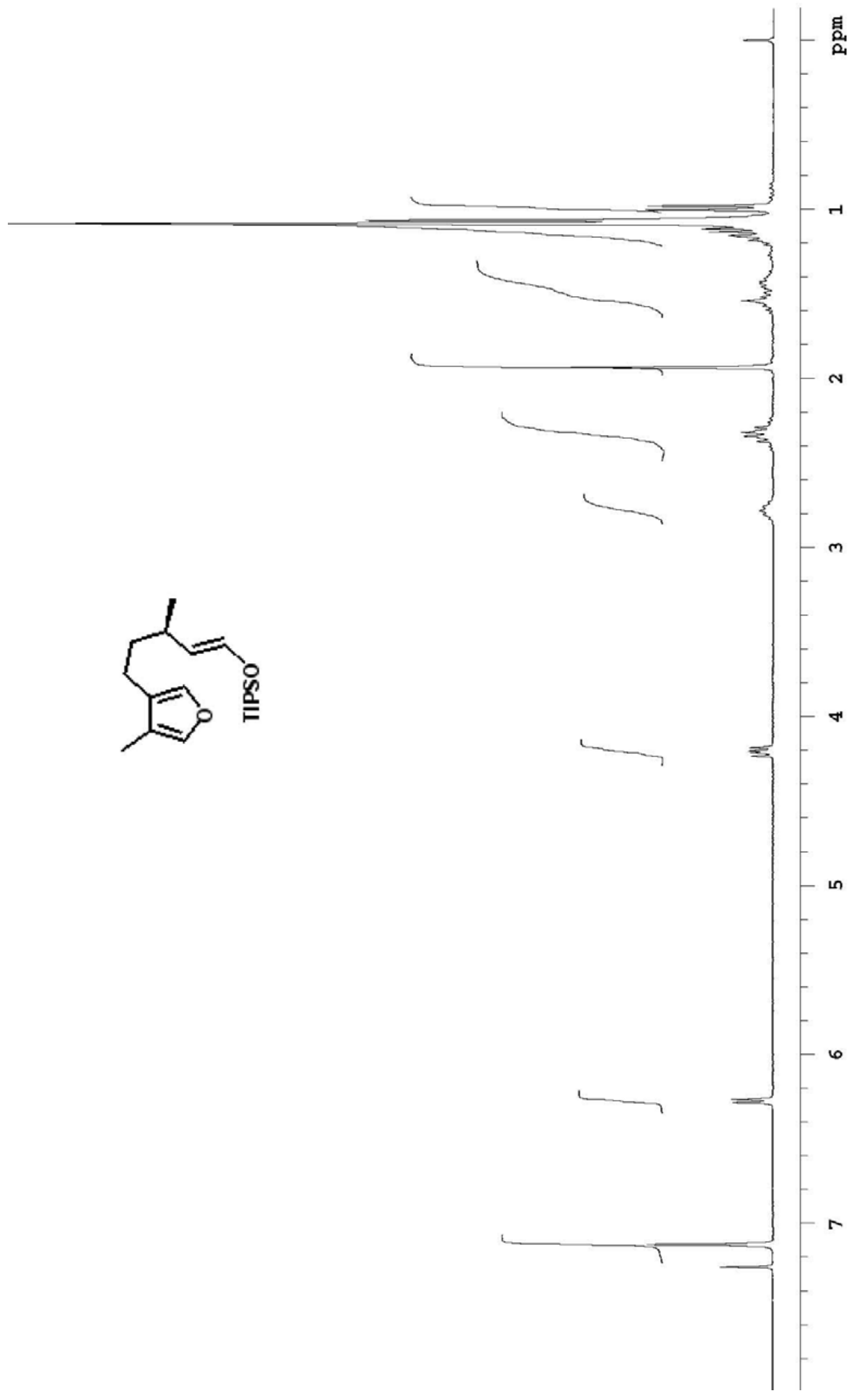

S-50 


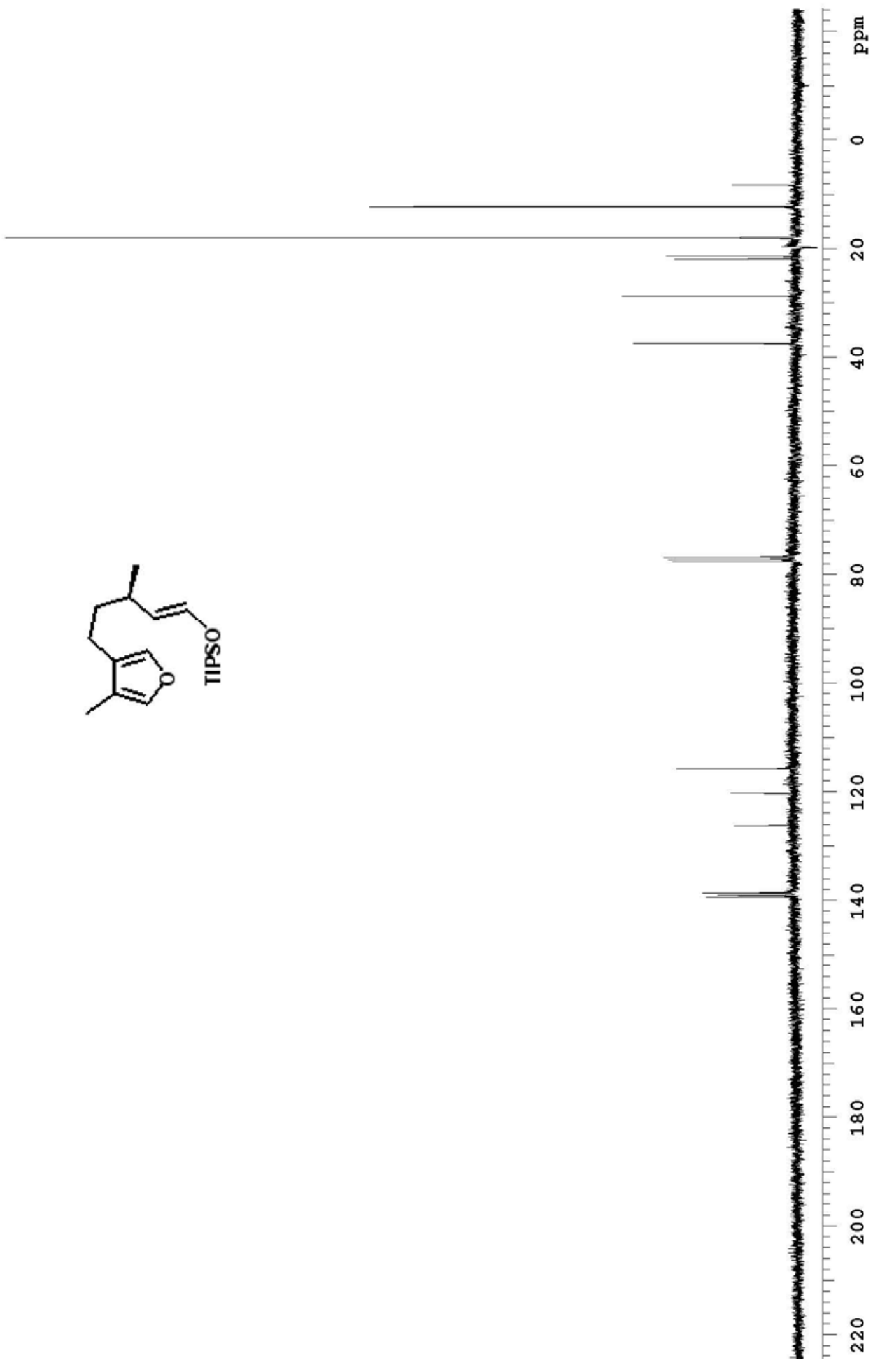

S-51 


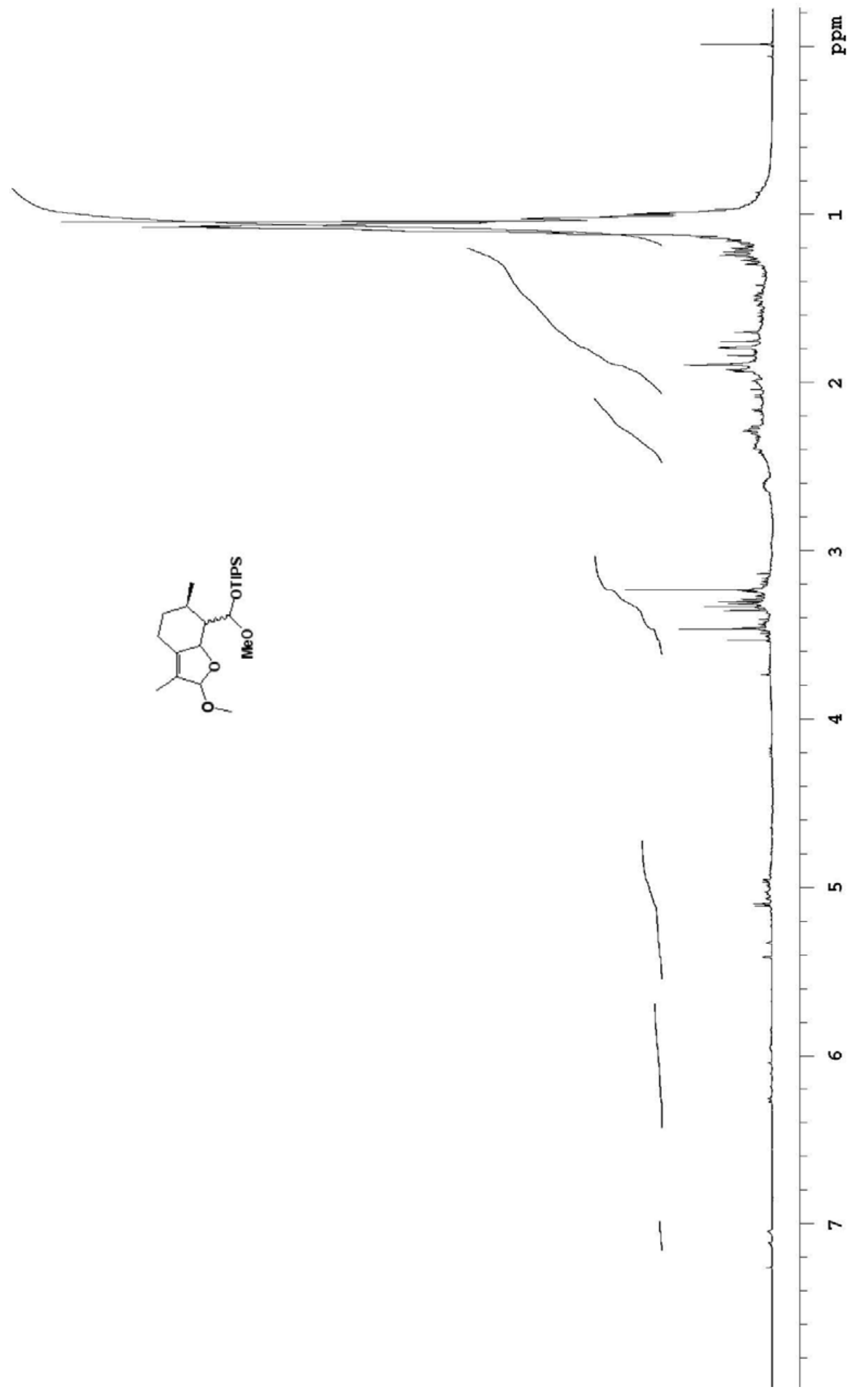

S-52 


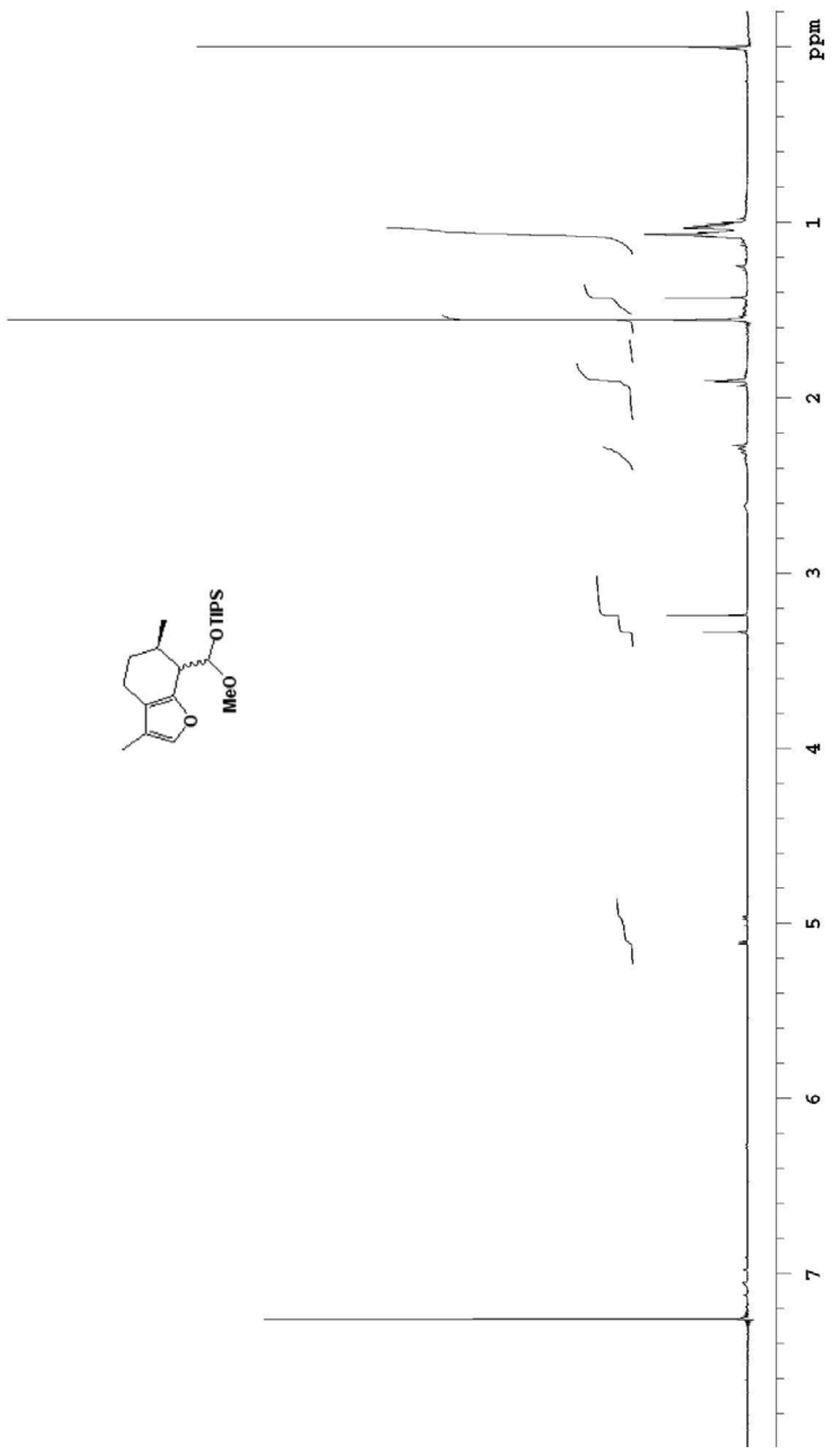

S-53 


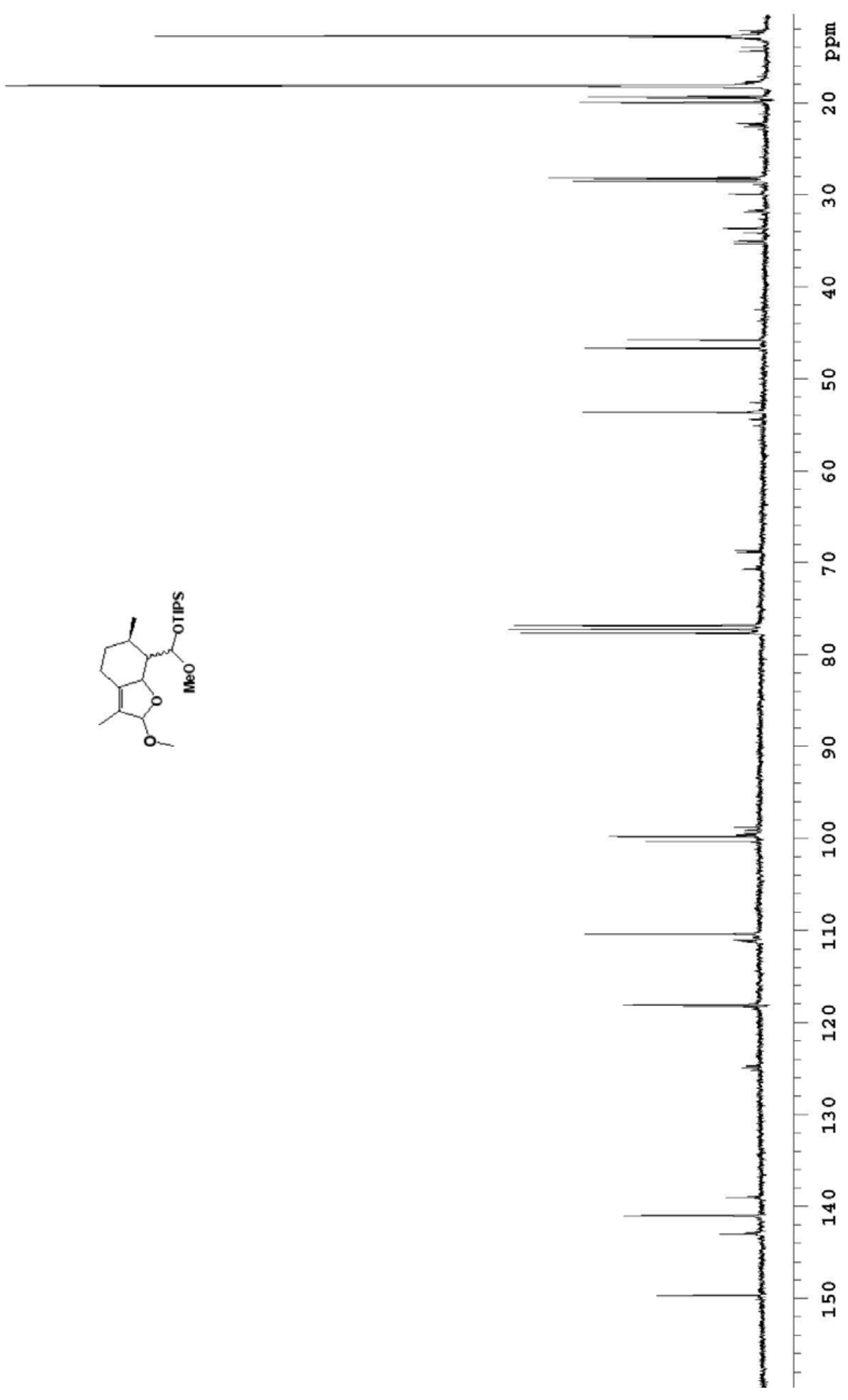

S-54 


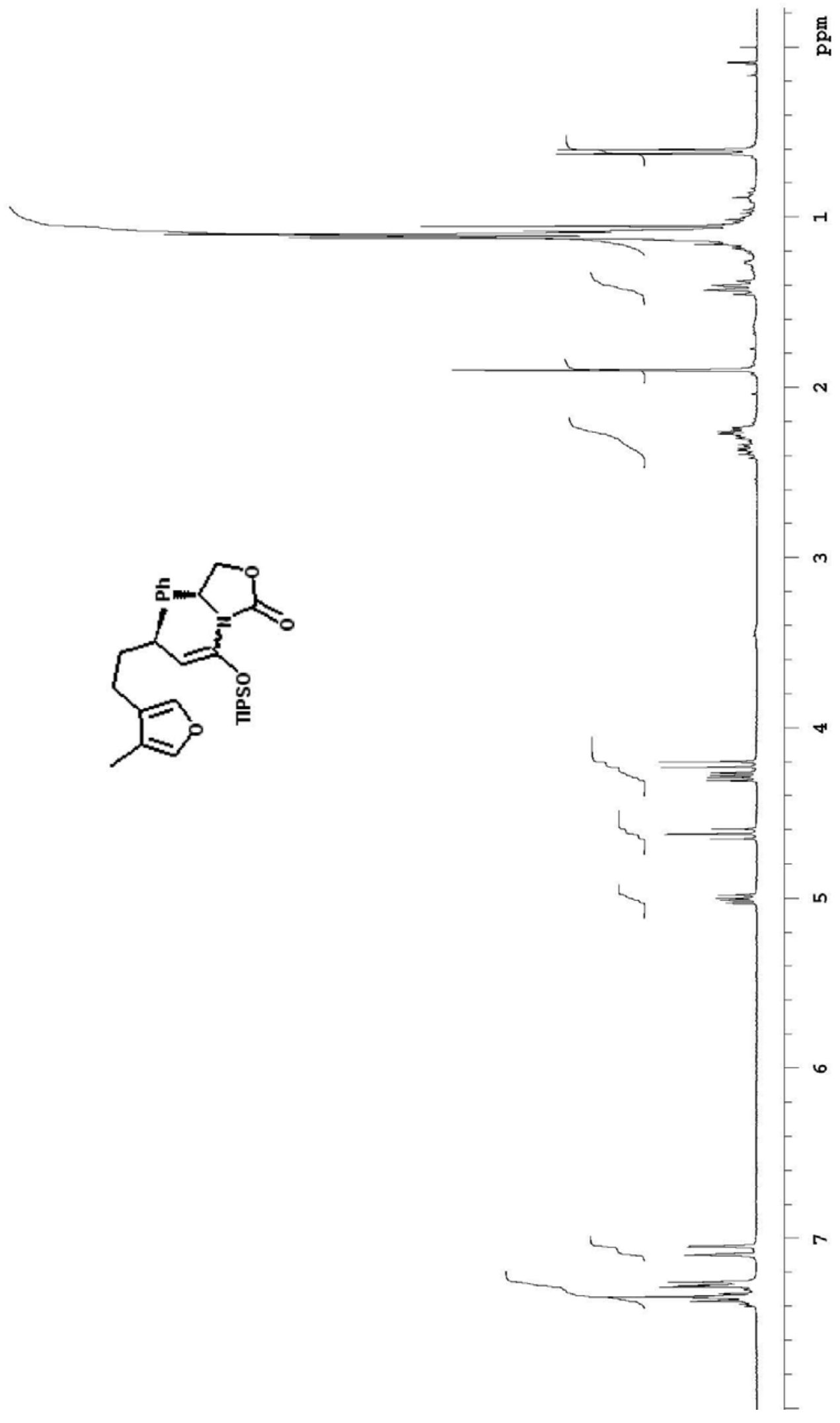

S-55 

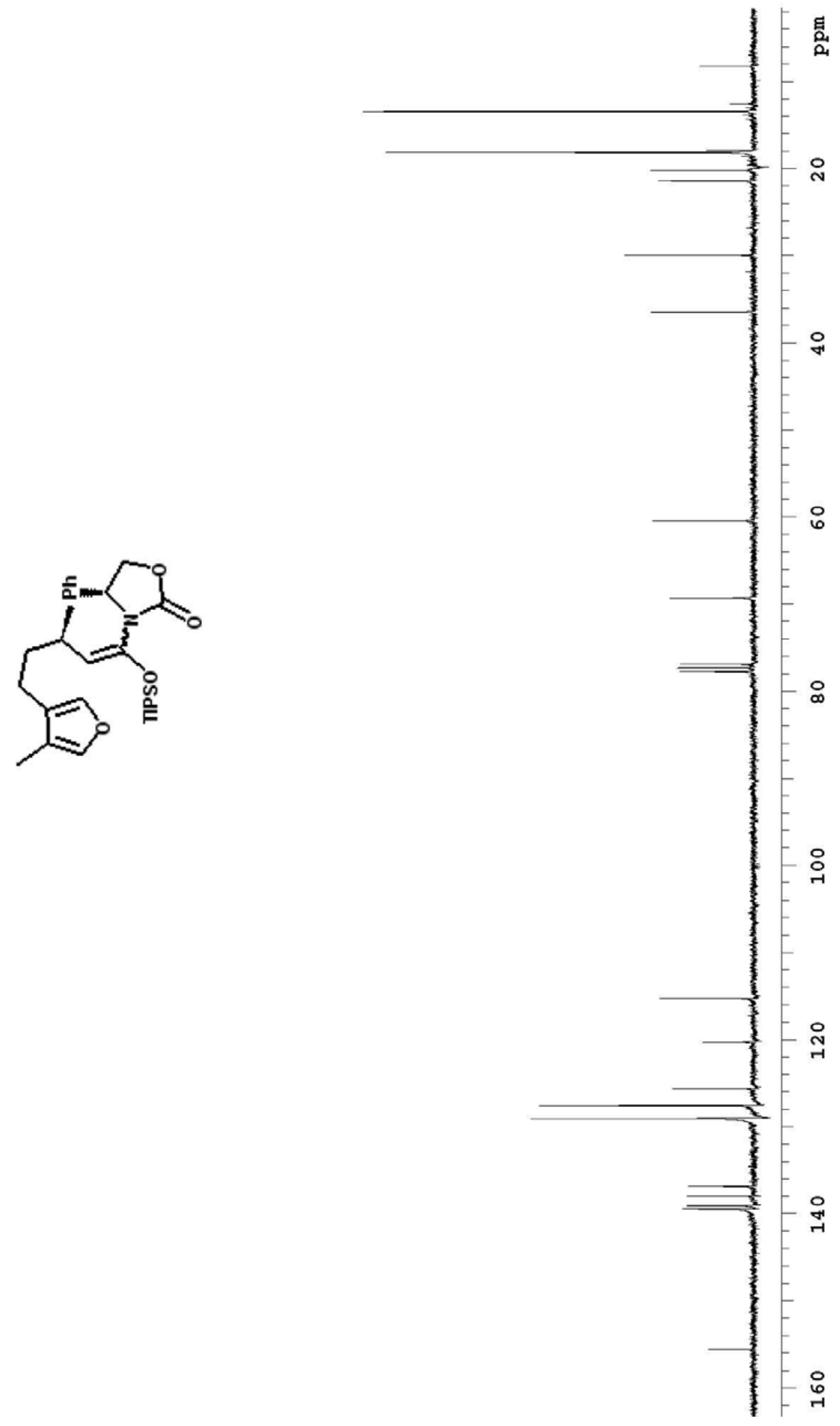

S-56 


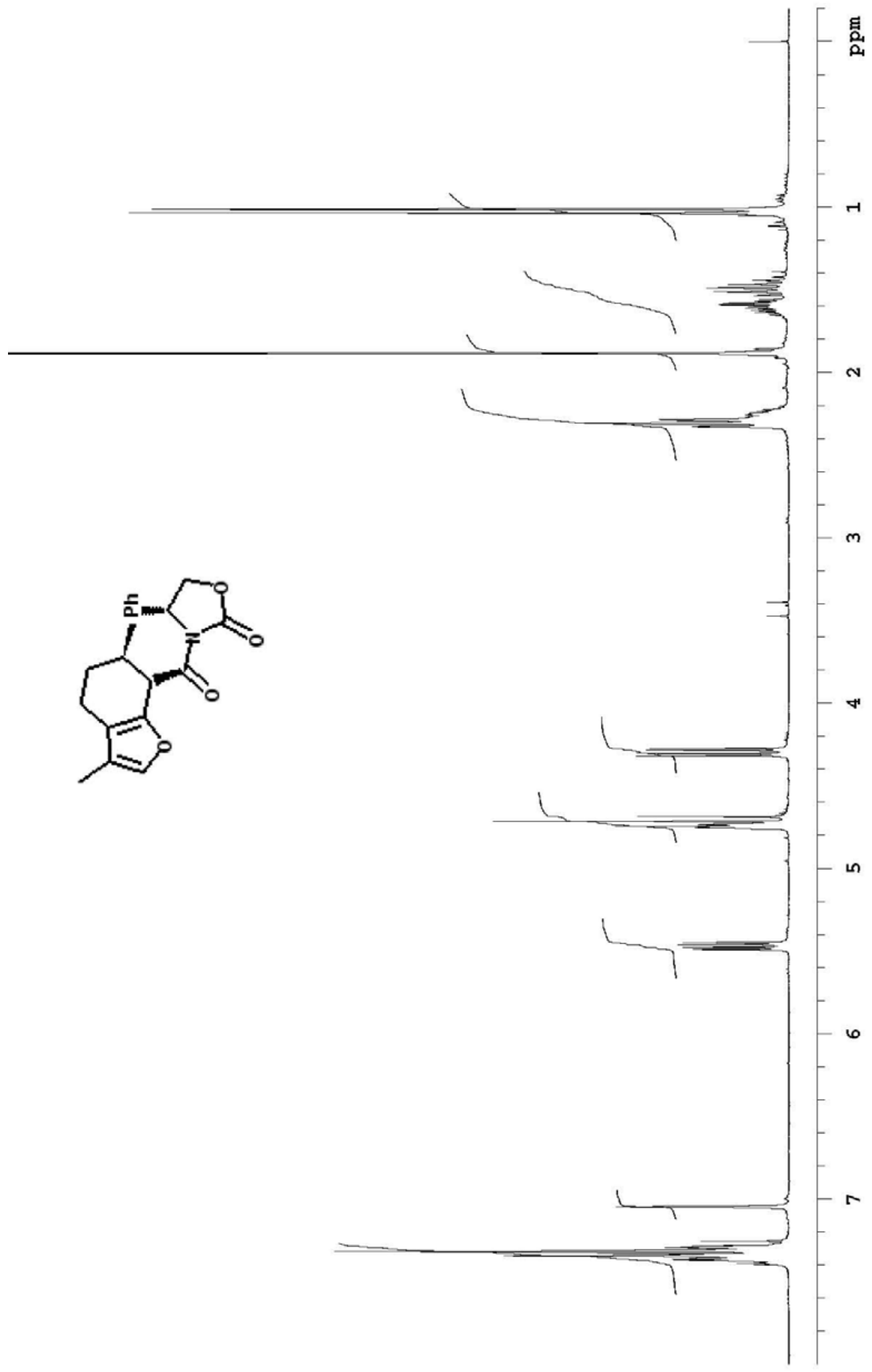




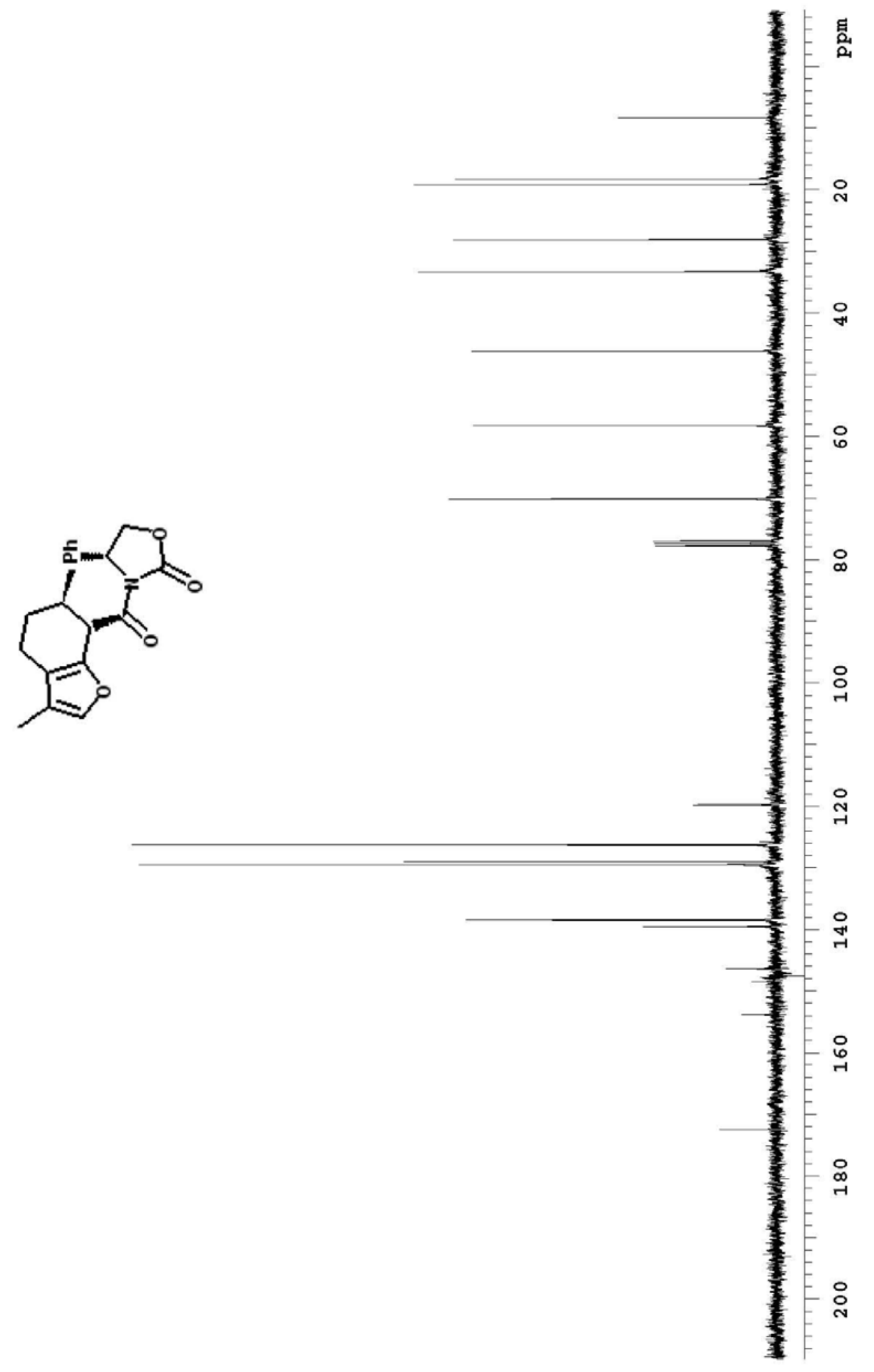

S-58 


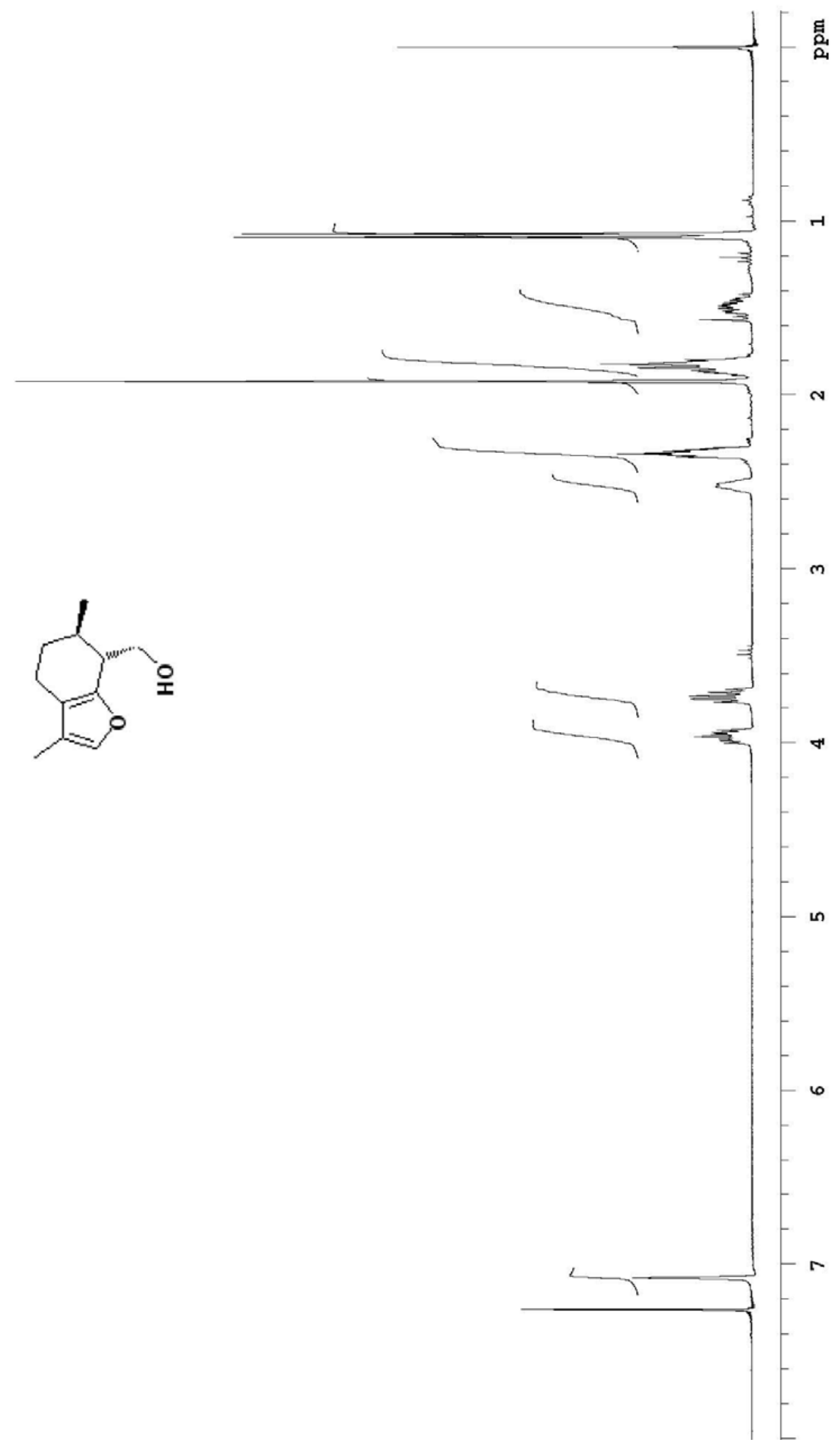

S-59 


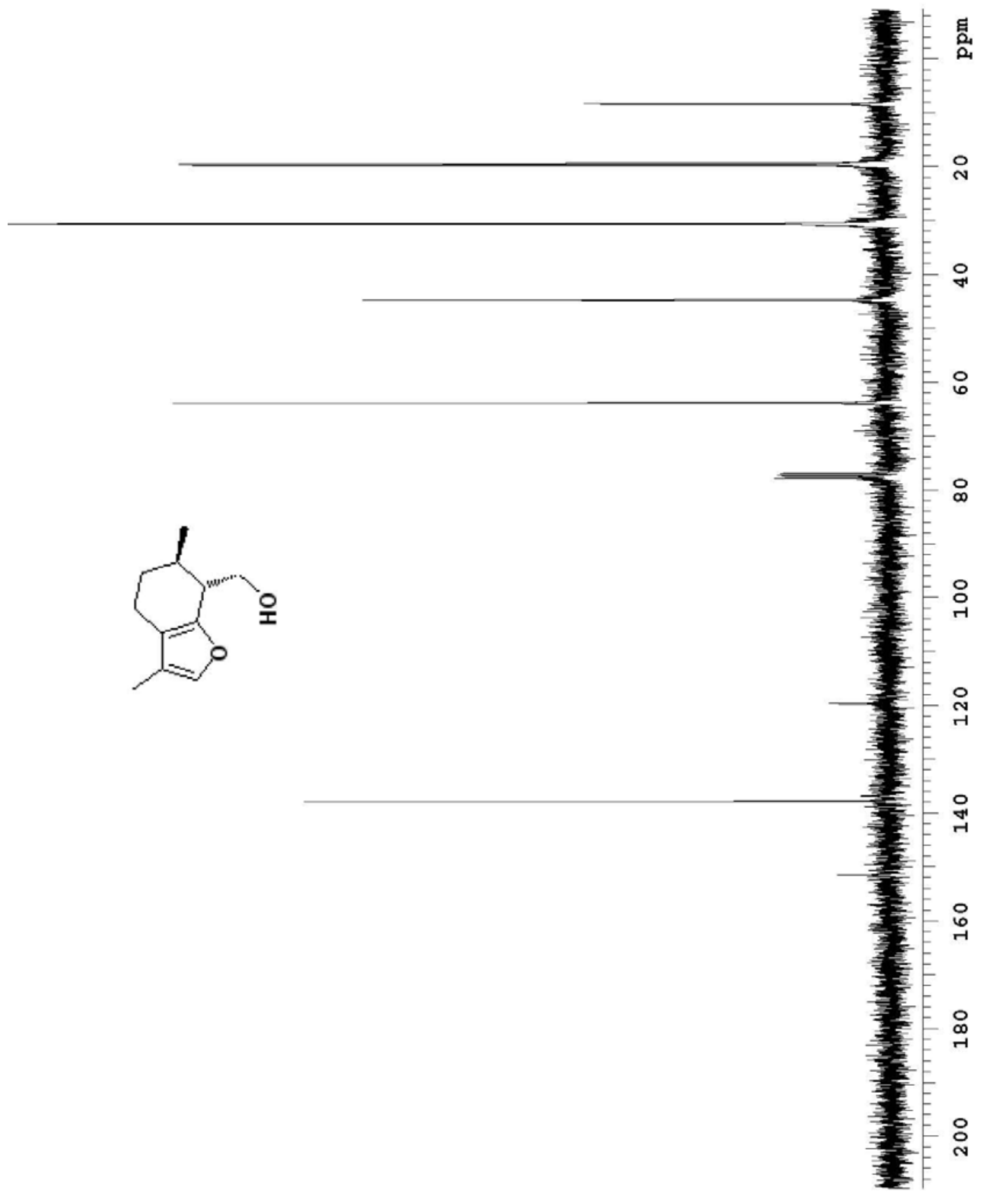

S-60 


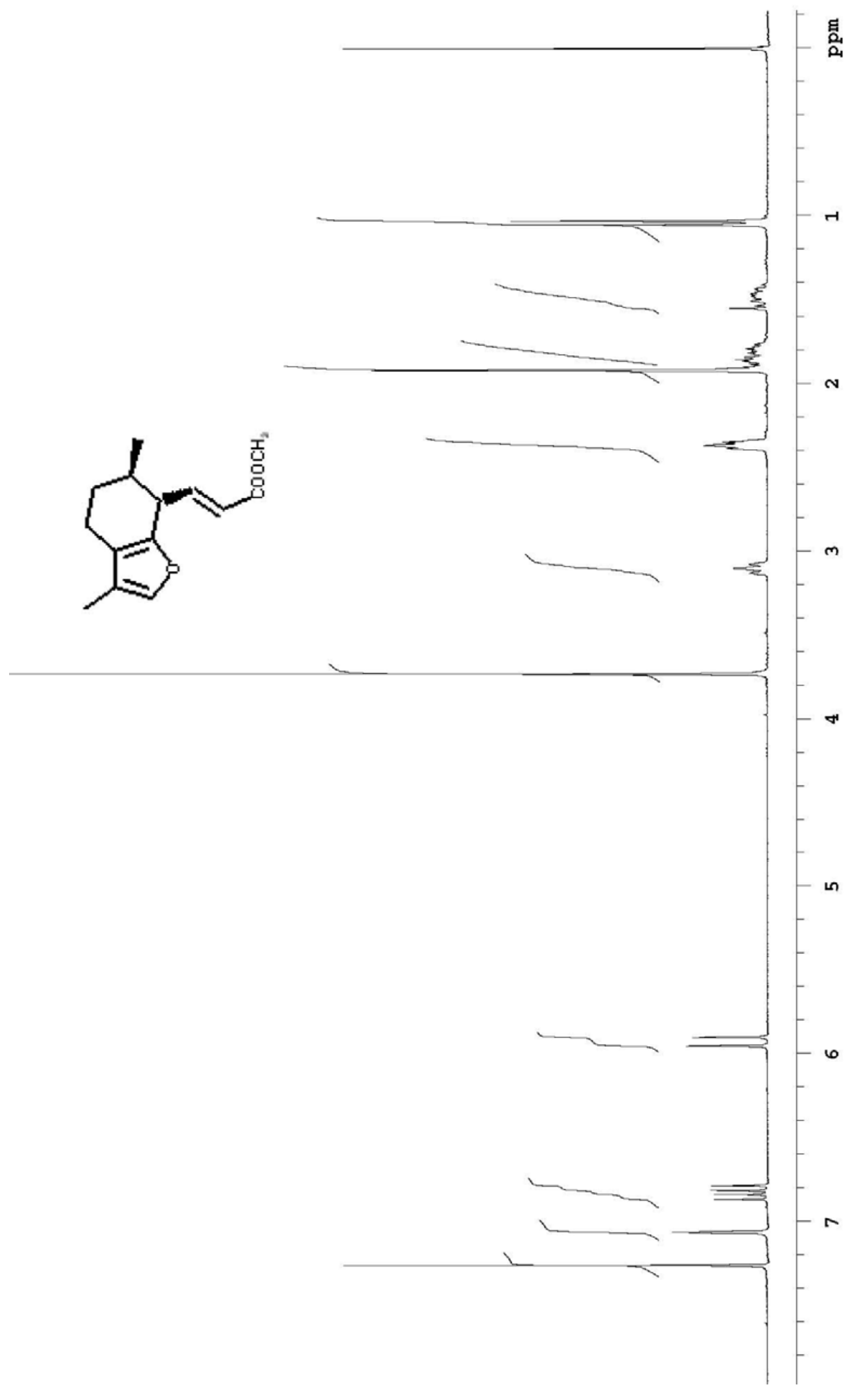

S-61 

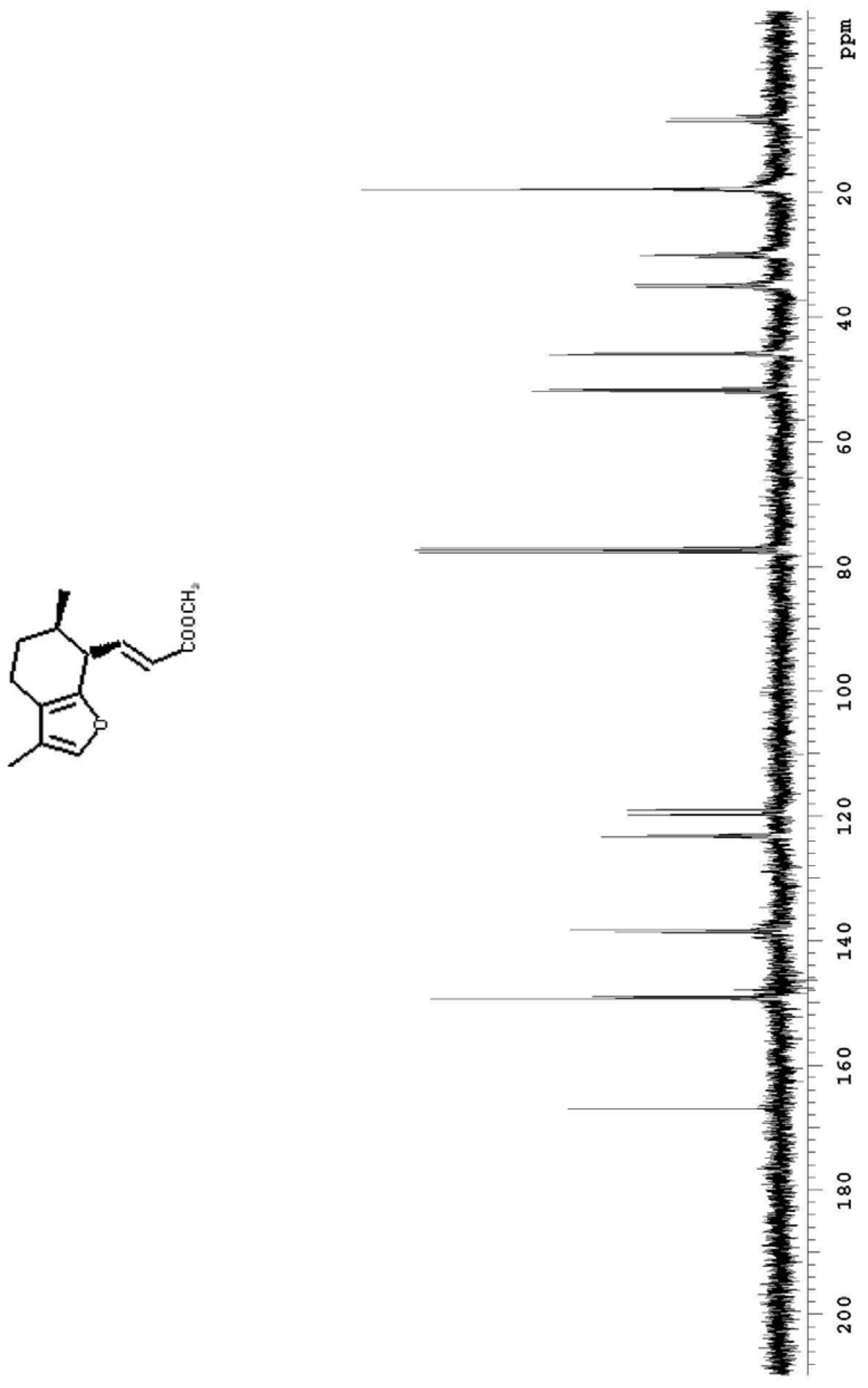

S-62 


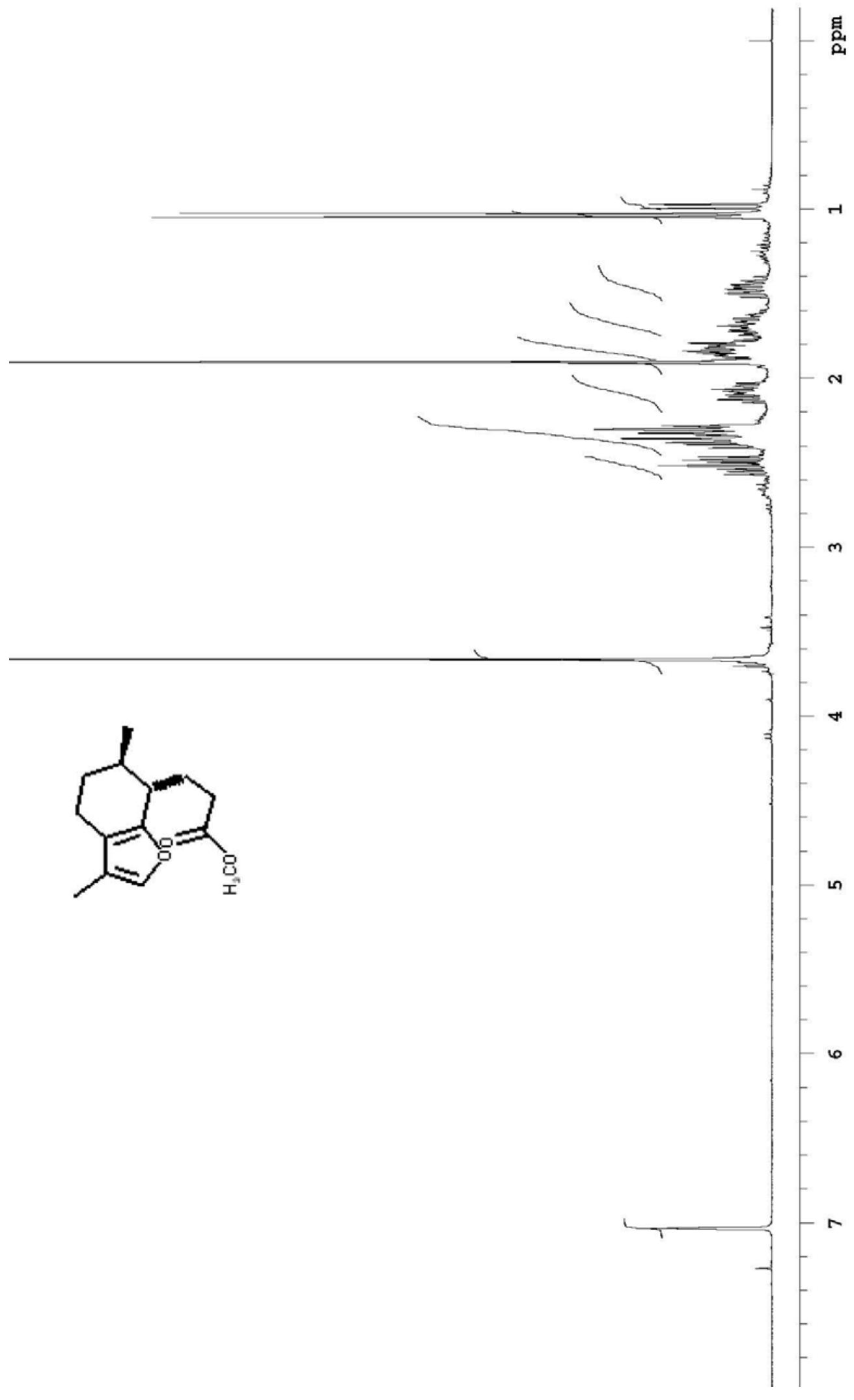

S-63 


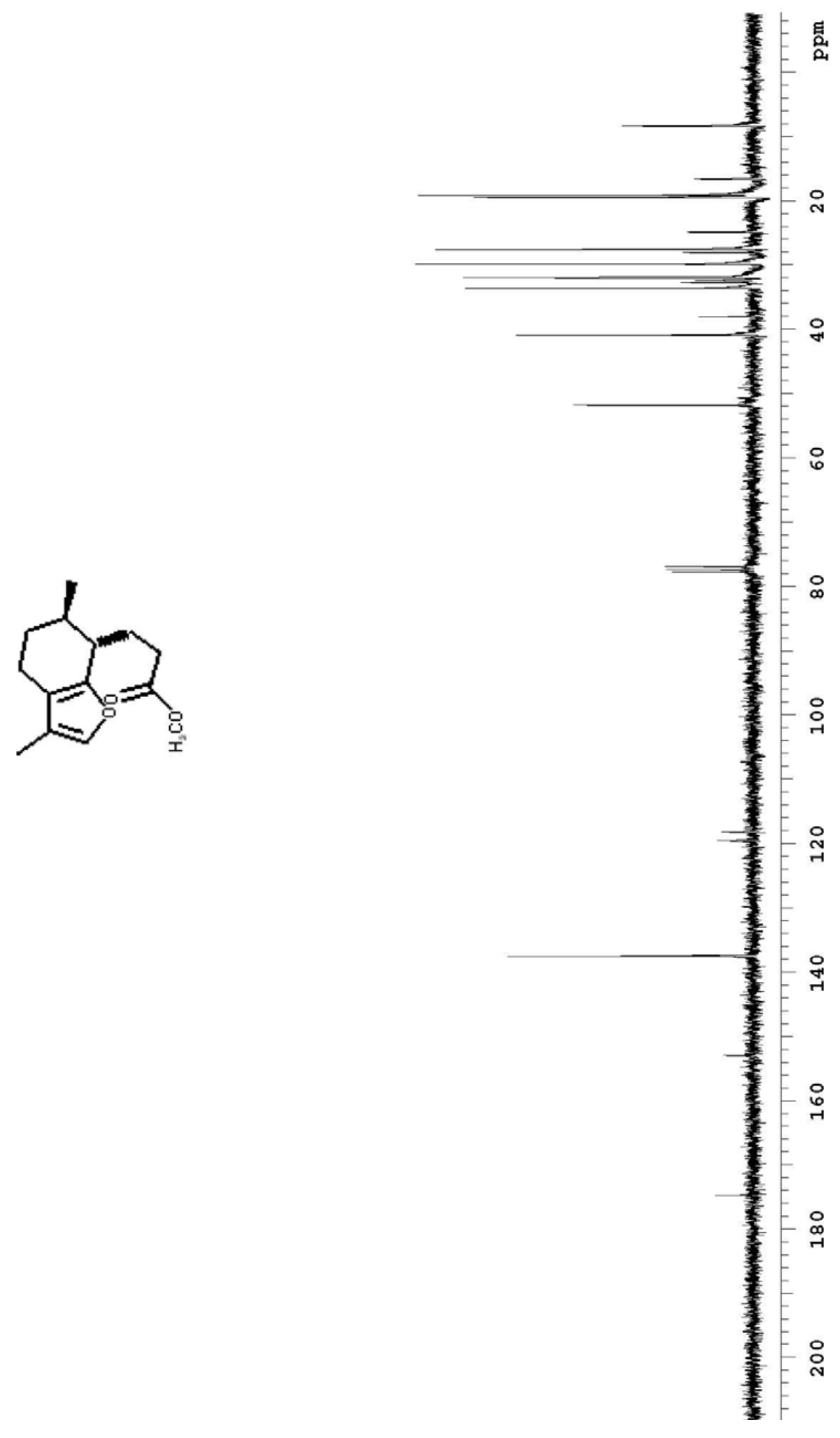

S-64 


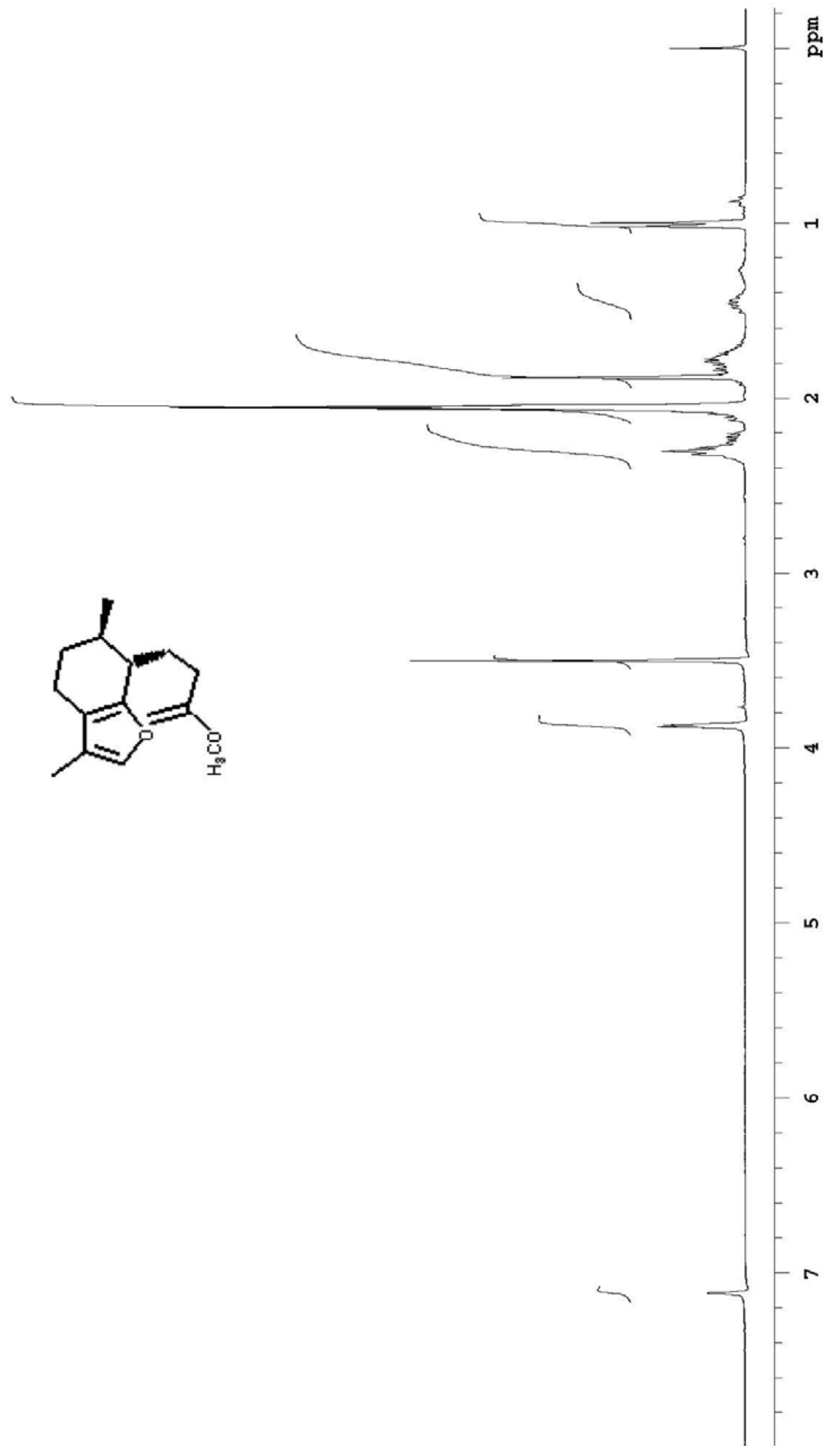




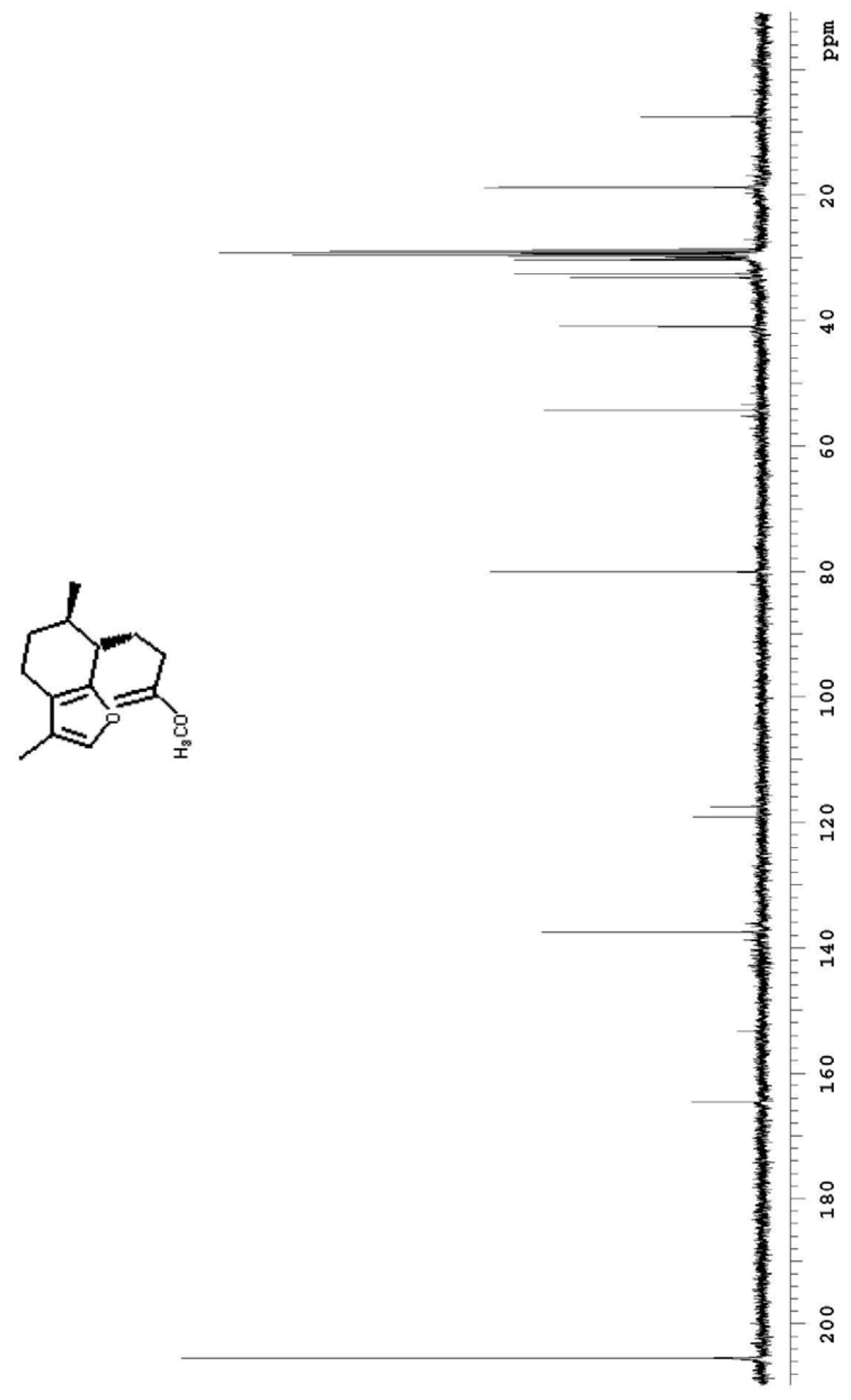

S-66 


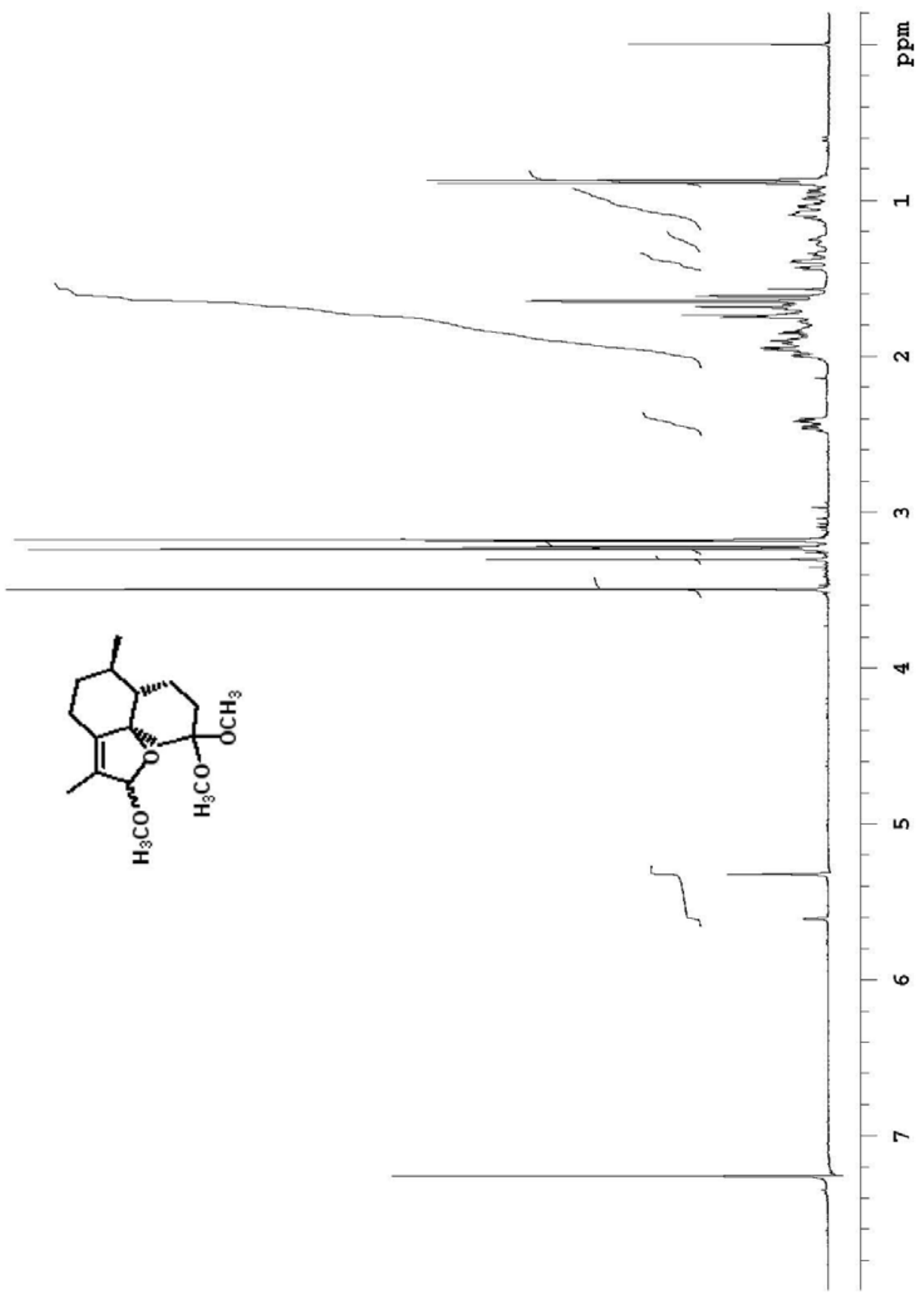




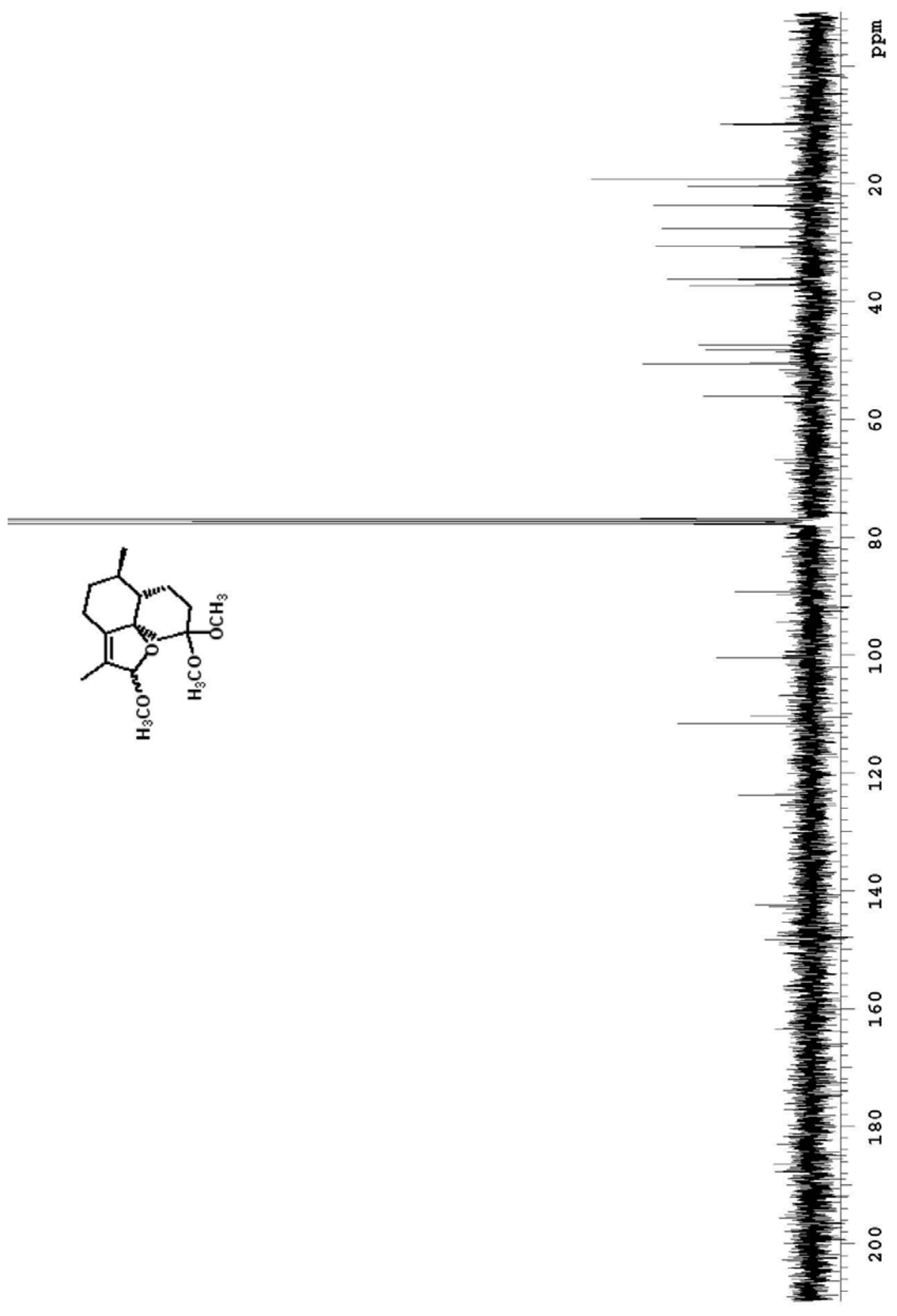

S-68 